Illinois State University

ISU ReD: Research and eData

Theses and Dissertations

$9-30-2020$

\title{
The Experiences Of Black Women In Diversity Roles At 4-Year Predominantly White Institutions
}

Tristen Brena Johnson

Illinois State University, tristenjohnson1@gmail.com

Follow this and additional works at: https://ir.library.illinoisstate.edu/etd

Part of the Higher Education Administration Commons

\section{Recommended Citation}

Johnson, Tristen Brena , "The Experiences Of Black Women In Diversity Roles At 4-Year Predominantly White Institutions" (2020). Theses and Dissertations. 1378.

https://ir.library.illinoisstate.edu/etd/1378

This Dissertation is brought to you for free and open access by ISU ReD: Research and eData. It has been accepted for inclusion in Theses and Dissertations by an authorized administrator of ISU ReD: Research and eData. For more information, please contact ISUReD@ilstu.edu. 


\section{THE EXPERIENCES OF BLACK WOMEN IN DIVERSITY ROLES AT 4-YEAR PREDOMINANTLY WHITE INSTITUTIONS}

\section{TRISTEN BRENAÉ JOHNSON}

\section{Pages}

Many Black women professionals at predominantly White colleges and universities share similar experiences regarding racism, sexism, and classism at their institutions. However, there is a dearth of research regarding the experiences of Black women who specifically work in diversity related positions at four-year predominantly White institutions (PWI). The purpose of this study was to explore the lived experiences of Black women who hold diversity related roles at PWIs. For the purpose of this study, diversity positions were defined as roles held in housing and residence life as well as in multicultural affairs departments and centers. Using a qualitative research approach and narrative inquiry design, I sought to understand how the lived experiences of Black women in diversity positions affect their ability to perform the daily tasks required by their roles.

This research study focused on Black women in diversity positions within student affairs units such as university housing and residence life as well as multicultural affairs departments and centers at eleven public four-year universities in the United States. The data was collected by conducting 11, one-hour, semi-structured interviews using the Zoom video conference platform. Data was then analyzed using thematic coding (Maguire \& Delahunt, 2017) through a Black Feminist lens, and four themes emerged. The results of the study revealed the following conclusions: a perception held by the participants regarding who is supposed to occupy diversity 
roles; Black women in these positions have to "bend" and "shift" (Harris-Perry, 2011) to navigate their predominantly White environments; Black women's relationships with White women, Black women, and Black men are either exceptionally positive or negative; and Black women often have to explore coping mechanisms to navigate their professional environments. The implications of this study challenges PWIs to consider allocating more financial resources to multicultural affairs/centers and diversity offices within housing departments, provide more pay and staff support for Black women diversity workers, commit to diversity and inclusion work throughout the entire university and not just in multicultural affairs, provide training for all members of the institution on diversity and inclusion efforts, and have accountability measures for repeat discriminatory behavior. This study hopes to encourage Black women diversity workers to use their voice and agency in their positions without fear.

KEYWORDS: Black, women, diversity, roles, housing, residence life, multicultural affairs, centers 
THE EXPERIENCES OF BLACK WOMEN IN DIVERSITY ROLES AT 4-YEAR

PREDOMINANTLY WHITE INSTITUTIONS

TRISTEN BRENAÉ JOHNSON

A Dissertation Submitted in Partial

Fulfillment of the Requirements

for the Degree of

DOCTOR OF EDUCATION

Department of Educational Administration and Foundations

ILLINOIS STATE UNIVERSITY

2021 
(C) 2021 Tristen Brenaé Johnson 
THE EXPERIENCES OF BLACK WOMEN IN DIVERSITY ROLES AT 4-YEAR

PREDOMINANTLY WHITE INSTITUTIONS

TRISTEN BRENAÉ JOHNSON

COMMITTEE MEMBERS:

Lydia Kyei-Blankson, Chair

Saran Donahoo

James Palmer 


\section{ACKNOWLEDGMENTS}

This dissertation is dedicated to Jalynn, Xsavier, Ayrin, Tylynn, Tyla Raé, Tyler, \& Tyland II, my nieces and nephews. I hope your "TT" makes you proud.

I first, want to give all thanks, honor, and glory to God. God, you said that you would never leave me, nor forsake me. During this dissertation process, there were times where I felt defeated, but you always brought me back to my path. I thank you for always being my lighthouse at the end of the stream when the nights down river seemed dark. My life is forever yours.

I thank all eleven of my participants: Monica, Dr. C., Jade, Skylar, Jurnea, Zion, Sasha, Sharice, Denise, Bailey, and Nubia. Thank you for your vulnerability and your willingness to tell it like it is. Diversity work is hard and emotionally taxing, and I forever will be in community with each of you. To my dissertation committee: Dr. Lydia, Dr. Donahoo, and Dr. Palmer. Wow. I could not have come this far without each of you. Dr. Lydia, thank you for your patience and your kindness. You inspire me to look deep into people's potential and tap into the best parts of them. Dr. Palmer, thank you for your encouragement, knowledge, and patience since course work in 2015. Dr. Donahoo, you've been my mentor since I was 22 years old in your graduate program at SIU Carbondale. You've been my confidant, my role model, and I thank you for being open and loving me unconditionally.

To Dr. Venus Evans-Winters, also known as Dr. V. Thank you for pushing me further in my thinking during this process. I admire the work you've done for Black women and girls and will forever look to you as the "boss chick" you are. You are an inspiration and real-life GOALS! I pray the ancestors continue to carry you to your ultimate destiny. 
To my parents, Trent and Wanda. Words can't begin to express how much I love you. I can tell how much God loves me because he saw it fit for you two to be my parents. You're always there for me and love me through whatever. Thank you for being my protectors. Thank you for supporting me. Thank you for existing.

DaNaē, Dominique, Mariah, Krystal, Dornecia, and Mesha, thank you for being there for me throughout this process and beyond. I love you, Black women. You are blessed, favored, and dedicated women and so much of who I am is because of you. $<3$

T. B. J. 


\section{CONTENTS}

Page

$\begin{array}{ll}\text { ACKNOWLEDGMENTS } & \text { i }\end{array}$

TABLES vii

CHAPTER I: INTRODUCTION - IT'S TIME TO SEE US 1

Purpose of Study 1

Research Questions

Description of Research Design 1

Background of the Study 2

Statement of Problem 4

Positionality of the Researcher - Where Do I Fit In? 6

Cultural Shifts and Changing Demographics, A Need for Diversity 9

Diversity Roles on Campus 11

$\begin{array}{ll}\text { Significance of Study } & 13\end{array}$

$\begin{array}{ll}\text { Definition of Terms } & 14\end{array}$

$\begin{array}{ll}\text { Limitations and Delimitations } & 14\end{array}$

$\begin{array}{ll}\text { Limitation } & 14\end{array}$

$\begin{array}{ll}\text { Delimitation } & 15\end{array}$

$\begin{array}{ll}\text { Conclusion } & 16\end{array}$

CHAPTER II: LITERATURE REVIEW - REAL LIFE. REAL TALK 17

$\begin{array}{ll}\text { Under His Eye } & 17\end{array}$

Workin' for White Folks - Black Women and Slavery 17

$\begin{array}{ll}\text { Havin’ Babies for Profit } & 20\end{array}$ 
We Slipped and Learned to Read

Anna Julia Cooper

Ain't I a Woman?

Anna's Daughters

Theoretical Framework - Black Feminist Thought

Conclusion

CHAPTER III: METHODOLOGY - WHAT ARE WE DOING?

Research Paradigm - Black Feminist Epistemology

Qualitative Research

Cultural Narrative Study

Data Collection

Participant and Site Selection

Data Analysis

Trustworthiness/Validity

Ethical Issues

Conclusion

Introduction

Section One Participant Narratives: Who is She?

Monica Shakespeare

Dr. Camille Reynolds

Sasha 
$\begin{array}{ll}\text { Jurnea Williams } & 70\end{array}$

$\begin{array}{ll}\text { Bailey Merrit } & 73\end{array}$

$\begin{array}{ll}\text { Skylar Rae } & 77\end{array}$

$\begin{array}{lr}\text { Jade Robinson } & 80\end{array}$

$\begin{array}{ll}\text { Nubia Jones } & 84\end{array}$

$\begin{array}{ll}\text { Denise Watson } & 87\end{array}$

$\begin{array}{ll}\text { Sharice Jones } & 90\end{array}$

$\begin{array}{ll}\text { Zion Johnson } & 93\end{array}$

Researcher's Note: A Familial Connection 96

Section Two: Emerging Themes $\quad 97$

Theme 1: Black Woman in Diversity 97

$\begin{array}{ll}\text { Theme 2: Standing in a Crooked Room } & 108\end{array}$

$\begin{array}{ll}\text { Theme 3: Nail in a Tire } & 116\end{array}$

$\begin{array}{ll}\text { Theme 4: Just Tryna’ Make It } & 123\end{array}$

$\begin{array}{ll}\text { Cross-Cultural Analysis } & 127\end{array}$

$\begin{array}{ll}\text { Conclusion } & 128\end{array}$

CHAPTER V - FINDINGS, RECOMMENDATIONS FOR PRACTICE, AND FUTURE

RESEARCH - Y'ALL GOTTA DO SOMETHING! 130

The Importance of Qualitative Research and Narrative Inquiry 131

The Importance of Black Feminist Thought to this Study 132

$\begin{array}{ll}\text { Overview of Chapter V } & 133\end{array}$

Findings of the Themes 134

$\begin{array}{ll}\text { Black Woman in Diversity } & 134\end{array}$ 


\section{TABLES}

Table Page

1. Demographics 58 


\section{CHAPTER I: INTRODUCTION - IT'S TIME TO SEE US}

\section{Purpose of Study}

The purpose of this study was to explore the lived experiences of Black women who work in diversity related positions at public four-year predominantly White institutions (PWI). For the purpose of this study, I delved into the lived experiences of those who perform diversity work within housing and residence life as well as multicultural affairs departments and centers. Using a qualitative research approach and narrative inquiry design, I sought to understand how the lived experiences of Black women in diversity positions affect their ability to perform the daily tasks of their roles.

\section{Research Questions}

The following research questions guided this study:

1. What are the experiences of Black women professionals who work in diversity positions? What aspects of their roles influence those experiences?

2. How do these experiences affect Black women's ability to perform the daily tasks of their roles?

3. What strategies do these women utilize to effectively perform their job responsibilities?

4. What can colleges and universities do to improve the work environments for Black women serving in diversity roles?

\section{Description of Research Design}

Creswell and Creswell (2018) define qualitative research as "an approach for exploring and understanding the meaning individuals or groups ascribe to a social or human problem” ( $\mathrm{p}$. 4). This approach was best suited for the current study given I sought to understand how Black women diversity professionals make meaning of their lived experiences at predominantly White 
institutions (PWI). Further, a transformative worldview was key to my qualitative inquiry. Creswell and Creswell (2018) posited that a worldview is often referred to as a paradigm, and a transformative worldview is "intertwined with politics and a political change agenda to confront oppression...an action reform agenda for reform that may change the lives of participants, the institutions in which the individuals work or live, and the researcher's life" (p. 9). Giving voice

to the participants empowers them as agents who will bring change to the work environments of Black women diversity professionals.

\section{Background of the Study}

Research regarding Black women's experiences as diversity leaders is important as student demographics in higher education and in the United States of America have become more diverse and universities having made efforts to increase the racial and cultural makeup of their student populations (Maraña, 2016; Shek, 2013; Woodlief, 2010). According to the National Center for Education Statistics (NCES) (2017a), Hispanic, Black, Asian/Pacific Islander, or American Indian/Alaskan Native students made up 15\% of the total college student population in 1976 and that percentage increased to $37 \%$ in 2016. Black female college student graduation rates have increased, and during the 2015-2016 academic year, of the Black students who earned bachelor's degrees, 64\% were Black female students (NCES, n.d.).

Because the student population is growing more racially diverse, it is important to have administrators who culturally reflect the students on their campuses. Although Black female students earn $64 \%$ of all bachelor's degrees granted to Black students (NCES, n.d.), the percentage of Black women who hold associate and full professor positions in higher education has not significantly increased (NCES, 2016). In 2005, $2 \%$ of associate professors were Black women and $1.2 \%$ were full professors (NCES, 2008). In 2015, this percentage only slightly 
increased to $2.6 \%$ and $1.5 \%$, respectively (NCES, 2016). Similarly, Black women represented $5.8 \%$ of student and academic affairs administrators in 2010 (NCES, 2010), a figure that increased to $11 \%$ in 2016 (NCES, 2017b). Although the percentage of Black women in faculty and administrative roles has increased, there is still much room for improvement.

There is an extensive body of research regarding Black women as tenured faculty members and Student Affairs administrators (Brown McManus, 2012; Candia-Bailey, 2016; Hodges \& Welch, 2017; Jones, Dawkins, McClinton, Glover, \& Brazzell, 2012; Sobers, 2014). Black women are often discriminated against based on their intersecting identities including race, class, and gender (Davis, 1981; Gray, 2017). One example of race, class, and gender discrimination is regarding Black women's hair styles. Gray (2017) conducted a study of tenured Black women faculty which focused on the ways their hair expression affected their professional experiences at predominantly White institutions (PWIs). Given the expectation that Black women adhere to Eurocentric standards of beauty, they often face scrutiny regarding the natural texture of their hair at PWIs. Gray (2017) found that her participants received varying comments about their hair choices before and after the tenure process. If their hair looked "neater", they received positive feedback from their White peers, but if their hair was in a style such as braids, they did not hear any feedback or they felt they were perceived negatively (Gray, 2017).

Reactions to their hair styling are the not only way Black women faculty members experience discrimination. Tenured faculty members are granted academic freedom to teach and explore research topics of their choice. However, Black women faculty are subject to more scrutiny than their White counterparts from White colleagues and students (Jackson \& Dorsey, 2009; Richardson, 2016; Robinson, 2018; Whitehead, 2017). Course evaluations from students are one of the tools used when considering faculty for tenure. Black women potentially spend 
copious amounts of time conducting their classes in ways which will, hopefully, yield positive course evaluations (Richardson, 2016).

\section{Statement of Problem}

The general problem is that Black women professionals in higher education may experience discrimination because of their race, class, and gender (Collins, 2000; Hodges \& Welch, 2017). However, the specific problem in this study was that Black women professionals who work in diversity-related roles are hired to implement diversity education programming but can be victims of the very problems they were hired to solve. Ahmed (2012) stated that diversity practitioners are expected to institutionalize diversity aims or goals set by their campus administrators. Institutionalization calls for diversity to be ingrained into the practices and culture of the entire organization, rather than in only one or two programs or subcultures. Interestingly, Ahmed (2012) also posited that "if institutionalizing diversity is a goal for diversity workers, it does not necessarily mean it is the institution's goal" (p. 22). In retrospect, diversity practitioners are often employed because the institution may lack diversity throughout the organization. Therefore, if the institution prioritized diversity, there would be no need for diversity practitioners (Ahmed, 2012).

Further, Patton (2016) discussed the connections between higher education institutions, Whiteness, power, and oppression, noting that, although colleges and universities mandate diversity be incorporated into the curriculum, the message of diversity still gets lost in the Eurocentric ways of teaching, which are sustained by an unwillingness to expand instructional approaches. Patton (2016) continued by saying, "diversity becomes so broad that racism and other issues that deal specifically with dismantling oppression get neutralized" (p. 321). My research explored the experiences of Black women who work in diversity related higher 
education positions. If colleges and universities incorporate diversity initiatives to foster the illusion that they value diversity, and if there is a risk that the message of diversity will become lost as institutions continue to uphold beliefs that benefit White ideals, how does this affect Black women who work in roles that promote diversity for these campuses?

Ultimately, diversity goes beyond representation on campuses. Swain (2013) said that diversity also incorporates campus "climate, education and scholarship, and overall institutional values and structures" (p. 2). If diversity is incorporated into these entities, then institutionalization can be "second nature" (Ahmed, 2012, p. 25) and a normal incorporation at higher education institutions. To institutionalize diversity means to ingrain it into cultural norms and practices (Ahmed, 2012).

I chose to study Black women diversity workers at predominantly White institutions (PWIs). This is important for two reasons. The first comes from Ahmed's (2012) description of how some view "diversity." She said that when a diversity worker is non-White, the organization may view that non-White person as someone who brings diversity to the campus simply because they are a person of color. This plays a role in institutional whiteness, the second factor that points to the importance of studying Black women diversity workers. Displaying a person of color at the forefront of an institution as a way of "bringing diversity" to campus does not mask the fact that the campus is predominantly White. Ahmed (2012) posited that simply adding people of color to all-White spaces paints a picture suggesting that the organization is, in fact, diverse and, as a consequence, reinforces the idea that diversity focuses on image. When this happens, she concluded, the focus is on "changing perceptions of whiteness rather than changing the whiteness of organizations" (Ahmed, 2012, p. 34). In this light, PWIs may be motivated to hire Black women as diversity workers who demonstrate that the institution is "diverse." Indeed, 
Patton (2016) lamented that people from historically marginalized backgrounds often carry the burden of doing diversity work on campuses.

\section{Positionality of the Researcher - Where Do I Fit In?}

In this section, I outline my personal experiences as a Black woman in residence life and in my first full-time diversity position. My reason for studying Black women in residence life who are engaged in diversity work was two-fold. First, residence life is a unique area of higher education which encompasses living and learning for students on campus, which is why one may hear residence life professionals refer to their buildings as "residence halls" instead of "dorms." The residence life department of Colorado Mountain College (n.d.), for example, explained that living in a residence hall is more than just an opportunity for students to "sleep." It is a chance for students to learn outside of the classroom.

The second reason involves my experience working in a residence life department, which had a unit dedicated to social justice concerns. That department assigned me to supervise a floor community devoted to social justice. This was one of my first roles working in student affairs in higher education. As a Black woman employee in this role, I oversaw two residence halls and the social justice floor was one small aspect of my position. The department expected me to educate the residents in my community about diversity and social justice, but simultaneously, my White supervisor allowed her implicit bias to affect the way she led. She often commented on my facial expressions and alleged that I looked "disinterested." In a one-on-one meeting her, she told me she did not want to see me on my cell phone anymore during staff meetings, but for a month after the conversation, I watched as she ignored my non-Black coworkers who constantly texted during meetings. Multicultural centers serve as places where students, staff, and faculty can learn about those who are culturally different from them, and they serve as "safe spaces" for 
historically marginalized groups (Pinchback-Hines, 2013; Shek, 2013). The Black Campus Movement of the 1950s and 1960s played a crucial role in the development of cultural centers (Patton, 2006). As student populations on college campuses have become more diverse over time, other race and culturally based centers have emerged (Shek, 2010). While multicultural centers and offices are credited with being safe spaces, they often bear the burden of being the sole place to experience diversity on campus. Patton (2016) posited that predominantly White institutions (PWIs) ignore their "commitment" to diversity by relying heavily on multicultural offices to do the diversity work and support students from marginalized communities.

The idea for this study stemmed from my own positionality as a diversity worker at a PWI. My diversity experience began in a residence life department but, thereafter, I switched to full-time diversity work in multicultural affairs at another PWI. Prior to my first full-time professional career as a diversity worker in multicultural affairs, I experienced discrimination in majority White offices in residence life. Without understanding the culture of the professional work environment of multicultural affairs, I believed discrimination only occurred in departments such as housing, financial aid, and counseling centers. These were areas in which I either had direct experience or had heard of the discrimination colleagues experienced working in these office spaces. During my short tenure in residence life, I felt isolated. When I left that functional area, I transitioned to my first full-time role in multicultural affairs at a PWI in an allWhite office. My job was to implement diversity programming initiatives on a predominantly White campus. It was in this role when I experienced discrimination more overtly.

I vividly remember the interview for my first full-time diversity position. I interviewed with colleagues who worked in the multicultural center (where this position was originally housed), and they raved about the program for which I was interviewing. They said the 
university was taking a step in the right direction to support underrepresented students on campus. The university created a committee who established the program after racial tensions on campus sparked between Black students and university administrators just one year prior to my interview. The Student Affairs department made organizational changes the day before I began my new role and moved my position out of the multicultural center and into an all-White office which housed first-year experience programs.

The start of my time in that office was a blur. Soon, feeling like an outsider became part of my daily routine. Waiting became an integral part of my workday. When I arrived at work, I waited for the daily email from my supervisor to inform me that I did not complete a certain task or to tell me that I did not "keep him in the loop" about something. After re-forwarding the emails I sent him weeks ago with the completed tasks attached, I waited for a White female coworker to ask a question of the Director about something pertaining to $m y$ diversity program. I waited to be told that I did not look happy. I waited to be told that I intimidated someone in the office.

I struggled to balance my commitment to facilitating a much-needed diversity initiative with defending myself against the incidents I experienced in my office. I spent approximately a month and a half defending myself against allegations from a White woman who claimed I had a sexually explicit conversation in the office. I questioned my purpose for being a diversity practitioner. How could I successfully implement a program that was supposed to assist the university in its inclusion efforts if I could not manage the oppression I felt in my own work environment?

I remember searching the internet for "support systems for Black women in diversity roles" or "how to run a diversity program while experiencing discrimination" just so I could find 
ways to perform the job duties related to advancing the institution's diversity mission, while battling oppression in my office environment. I found research studies which focused on Black women as both faculty members and Student Affairs administrators but not much about Black women in diversity related positions. This presented an opportunity for me to explore what these women experience in their specific roles. Responses to the research questions of this study provide PWIs tools to support Black women in these positions as they work to assist the institution in meeting their institutional goals for diversity.

\section{Cultural Shifts and Changing Demographics, A Need for Diversity}

Data regarding changing student demographics, noted at the beginning of this chapter, reflect the growing diversification of the college student population during the past 15 years. However, this is not the first time higher education has seen a change in the racial diversity of the students enrolled at colleges and universities across the country. During the 1950s, 1960s, and 1970s, the United States of America experienced a shift in the political, social, and human rights of Blacks brought about by the Civil Rights Movement. State and federal laws prohibited Blacks from voting, sitting at lunch counters and, in many cases, enrolling at PWIs. College campuses functioned as reflections of the larger American political arena. Black students enrolled at PWIs and historically Black colleges and universities (HBCUs) fought for equal rights in both their communities and on their campuses. The Black Campus Movement (Rogers, 2010) at both PWIs and HBCUs paved a way for higher education to expand the number of Black students on campus as well as the educational experiences available to these students. Black students demanded a curriculum which reflected their experiences, advocated for ethnic cultural centers, led the call for an increase in the number of Black faculty and staff on campuses, and pressed college and university leaders with a multitude of other demands which 
reflected the Black experience (Rogers, 2010). Some of these demands included an increase in the number of students of color, and at San Francisco State college, for example, the rehiring of a Black staff member previously fired for his involvement with the Black Panther Party (Biondi, 2012).

The Black Campus Movement is just one of the social movements in higher education that changed the scope of services provided by institutions. The Stonewall Riots of 1969, (Marshall, 2017) provided the spark that initiated the fight for the rights of lesbian, gay, bisexual, transgender, and queer (LGBTQ) students on college campuses. Police raided a gay club in 1969 in the state of New York, and protests followed this incident for days (Stulberg, 2018). Marshall (2017) stated that students at Cornell University advocated for the creation of student organizations for LGBTQ students after the Stonewall incidents, and soon these organizations were established on over 150 campuses across the country, with the first LGBTQ resource center opening in 1971.

The Black Campus Movement, along with the movement centering on the rights of the LGBTQ students, demonstrated a need for campuses to incorporate resources that support the changing, more diverse student populations. As stated above, student demographics of today are evolving. Diversity in higher education is not just a concept related to Black students or students who identify as LGBTQ. Williams (2013) stated that the push for diversity education led to the creation of diversity offices and other inclusion-based programs which assisted students who had previously been denied access. However, Williams (2013) also suggested that this should not be the only way we think about diversity and that, for higher education institutions to compete globally, they must strive for higher standards of institutional performance. Essentially, higher education institutions must strategically plan for diversity initiatives. 
It is important to describe the term diversity, for the purpose of this study. However, the term diversity has been difficult to define (Visser, 2015; Williams, 2013). Visser (2015) indicated that higher education institutions have created their own definitions of the term as they look to "embed inclusivity into the legacies of colleges and universities" (p. 6). Williams (2013) utilized the term diversity idea as a framework for understanding the complexity of diversity. The diversity idea consists of four interconnected parts. The first, conceptual perspective, posits that language is ever changing and is hard to conceptualize. Second, the group identity perspective states that although one can be part of a group (i.e. a Black woman being a member of a group of people who are Black), individuals still have their own identities within that group. Third, the ideological perspective posits that there are various ways (equity, racial, economic, etc.) in which we understand diversity. Lastly, the institutional perspective states that diversity is "crystalized in formal institutional definitions and statements of policy that expresses what the institution values" (Williams, 2013, p. 85). All four of these perspectives are needed to operationalize diversity as a multifaceted feature of institutional settings. Swain (2013) stated that diversity represents differences in thought, experiences, cultural expectations, and social identities such as race, sex, ability, and a multitude of other constructs. For the purpose of this study, I used Swain's (2013) concept and all four of Williams' (2013) definitions of diversity, because the perspectives of both authors are tangibly related to the purposes of multicultural centers and university housing.

\section{Diversity Roles on Campus}

Research has highlighted Black women's experiences as faculty, administrators, and Student Affairs professionals in general (Carter-Frye, 2015; Gardner, Barnett, \& Pierson, 2014; Hodges \& Welch, 2017; Jones et al., 2012), but there exists very little research regarding Black 
women's experiences in diversity roles at higher education institutions. Edgehill's (2007)

research on Black women in race- specific roles in higher education explored various economic and social shifts in the country and their relation to Black women in the workforce. Edgehill (2007) found that the "diversity related" positions on campuses were usually occupied by Black women because these positions were seen as low-level and the "cheapest source of domestic labor to maximize profits in a global market of white higher education" (p. 251). Edgehill's (2007) study focused more on the role of Black women's labor in a capitalistic society rather than what these women experience, daily.

In her 2013 study about the agency and positionality of women of color serving as chief diversity officers (CDO), Monica Nixon (2013) found that their work experiences were similar to those of other diversity practitioners. Three out of five of her participants identified as Black or African American, and the other two identified as Latina. Some cited instances of feeling ostracized, which motivated them to perform diversity work. The women were determined to help institutionalize diversity on their campuses despite the negative comments surrounding their identities as both women and persons of color. Despite being subject to negative comments, they all felt their identities had meaning in their roles as chief diversity officers, suggesting that although they experienced acts of discrimination, they wanted to continue to serve as role models for others from marginalized backgrounds (Nixon, 2013).

Maraña's (2016) dissertation explored the "lived experiences" of women of color who worked as CDOs at their institutions. The study participants were Latina, Black, and Asian. Maraña (2016) found the participants shared a pride in their racial and gender identities as CDOs but experienced discrimination in their workplaces. Although this study highlighted women of color in diversity positions, and although some of their experiences were similar, the study 
offered minimal insights into the experiences of Black women, specifically. Rather, the study grouped all women of color together and examined their experiences, collectively. If the stories of Black women are to be fully understood, they need to be targeted in the research. My study, therefore, focused specifically on the voices of Black women in diversity roles. It is important to understand these women's experiences as they are hired to perform the work that their institutions claim to value.

\section{Significance of Study}

The studies reviewed above center on chief diversity officers, in general. My study focuses specifically on Black women who perform diversity work in housing and residence life as well as multicultural affairs departments and centers. My study explored the experiences of Black women as diversity practitioners in other offices at predominantly White institutions (PWI). My study contributes to the growing body of literature regarding Black women professionals in higher education and helps higher education administrators understand the challenges Black women face while educating campus constituents about diversity and inclusion. Qualitative research regarding Black women professionals in academe has highlighted Black women as faculty members and administrators, but few studies have focused on Black women who work in diversity roles in housing and residence life as well as multicultural affairs. It is important to study this topic given Ahmed (2012) explained that people of color are typically overrepresented in diversity roles at PWIs. Studying the experiences of Black women in these roles highlighted how institutions, "long celebrated as a purveyor of progress and opportunity, is systemically and en masse indebting Black women then disposing of their bodies and their intellectual contributions, as well as their potential" (Nzinga, 2020, p. 2). In other words, this research can be used as a metaphorical mirror that institutions can hold up to themselves. They 
can use this mirror to look inward to see which policies, cultural norms, individuals, etc. are being upheld which push Black women in diversity roles to the margins and hinder their ability to perform the diversity role they were hired to do. Thereafter, PWIs can begin to make systemic changes to support these women. Also, this research would benefit the institution, as a whole, given that reflection will allow them to demonstrate their commitment to diversity. Finally, if PWIs continue to recruit, hire, and retain Black women in these diversity roles, this study may provide useful strategies to help meet these institutional goals.

\section{Definition of Terms}

In this dissertation, I used the term Black, defined as people who identify as Black, African American, having roots in the African diaspora, multiracial, Caribbean, and African (Arjun, 2019; Miles, 2012). Although my participants all lived and worked in the United States of America, classifying all of them as "African American" would not be representative of their cultural upbringings.

\section{Limitations and Delimitations}

According to Creswell and Creswell (2018), researchers who conduct qualitative research act as instruments for their studies and do "not tend to use or rely on questionnaires or instruments developed by other researchers" (p. 181). I created the interview questions and analyzed the data from my participants (Creswell \& Creswell, 2018). As the sole researcher, I recognized that my experience as a Black woman diversity worker at predominantly White institutions (PWI) influenced the way I interpreted the data collected.

\section{Limitation}

The study is bound by the decision to focus on PWIs. As a consequence, the study does not address the experiences of Black women at historically Black colleges or universities 
(HBCUs). Patton (2016) posited that racism helped construct HBCUs because White missionaries founded many of these institutions with the beliefs that Black folk were “intellectually inferior" (p. 331). Johnson (2018) also highlighted how HBCUs have been negatively portrayed in the press regarding educational quality, graduation rates, and financial management. Nonetheless, Johnson (2018) found that her participants valued their HBCUs and the relationships built with professors and staff. Focusing on Black women at HBCUs would have changed the scope of the study given HBCUs encompass mostly Black students, staff, and faculty. Black women's racial identities would be considered differently at an HBCU where she would be more likely to see her race overrepresented rather than underrepresented like at a PWI. Green (2019) found that his Black faculty participants embraced other aspects of their identities outside of their race. My study sought to understand the experiences of Black women who perform diversity work, specifically at PWIs, where they are not the racial majority on campus.

\section{Delimitation}

One delimitation of this study was my choice refrain from interviewing the colleagues of my participants. Black women's stories were key to the development of this study, which is why I chose narrative inquiry. Both Collins (2000) and Evans-Winters (2019) explained the importance of Black women's stories to qualitative research and how Black women are creators of their own knowledge. Because of this, I did not seek to understand how their colleagues interpreted their experiences.

Finally, this study does not account for the experiences of Black transgendered women. Although I acknowledge that transgendered women are women, my study focused on women who were biologically born female because of my positionality in this research. Because transgendered women's assigned sex at birth was male, they may have different gender 
experiences in their lives than someone whose assigned gender at birth was female.

\section{Conclusion}

This introduction provided background information regarding Black women in faculty and administrative positions at PWIs, a brief overview of diversity in higher education, the conceptual framework, the research questions, and definition of terms. The following chapter, which reviews relevant literature, introduces the theoretical framework of Black Feminist Thought. It also explores the historical, political, social, and economic contexts of Black women at work, during the Women's Suffrage Movement, in their quests for education, and in the student affairs field today. Chapters Three, Four, and Five respectively outline the methodology, the emerging themes, provide recommendations for practice, and offer future study suggestions. 


\section{CHAPTER II: LITERATURE REVIEW - REAL LIFE. REAL TALK.}

The purpose of this study was to explore the experiences of Black women who work in diversity related positions at predominantly White institutions (PWI). This chapter examines the literature regarding Black women's roles as workers, educators, and Student Affairs professionals in higher education. First, the chapter presents an overview of the historical, political, social, economic, and cultural context of Black women at work, in education, and in Student Affairs today. Then I provide a review of the theoretical framework which guided my study, Black Feminist Thought (BFT) (Collins, 2000).

\section{Under His Eye}

In her 1985 novel The Handmaid's Tale, Margaret Atwood described a dystopian society in which subjugated women lived under constant watch of a male patriarchy; they lived, what Atwood's characters described as, "under his eye" (Urquhart-White, 2017, para 1). This is an apt title for this section of the dissertation, which highlights the historical and economic contexts of Black women as workers. It provides an overview of the experiences Black women had as slave laborers and the types of work available to them after emancipation. During the antebellum period, enslaved Black women were under constant surveillance ("under his eye”) from overseers, masters and mistresses, and community members. After emancipation, Black women were still "under his eye" in a society that severely limited the types of jobs they could perform.

\section{Workin' for White Folks - Black Women and Slavery}

Understanding Black women's roles in oppressive environments during slavery provides a foundational overview of how Black women have been labeled as workers in society. It also provides an important context regarding how the Black women in my study perform diversity work at PWIs, today. Ultimately, the current experiences of Black women connect to the 
experiences of Black women during slavery. A controlling image of Black women is that of the "mammy", a servant for White people (Collins, 2000) and a stereotype from whom remnants exist today.

Gordon-Reed (2018) lamented that White Americans placed Blacks in inferior positions in society as a way to maintain dominance. This dominance helped create laws that denied basic human rights to Blacks, keeping them in bondage. Gordon-Reed (2018) explained that Whites were able to "maintain a system of social control over the enslaved" because they could identify Blacks by their skin color, facial features, etc.” (p. 4). Black people are still easily identified today because of their physical features. Harris-Perry (2011) posited that White people's controlling ideals still play a key role in the types of jobs Black women receive. Harris-Perry (2011) called this "standing in a crooked room" because "it is painful to labor under negative stereotypes" (p. 42) assigned to Black women by dominant ideologies.

Slavery in the United States played a key role in the exploitation of Black women's labor. Davis' (1971) article, "Reflections of the Black Woman's Role in the Community of Slaves" and Davis' (1981) book, Women, Race, and Class provide crucial scholarship regarding this topic. Davis (1981) attested that prior to her research, the limited scholarship on enslaved Black women depicted them as sexually promiscuous and perpetuated the stereotype of the "mammy". Davis' (1981) book was followed by Fox-Genovese's (1988) Within the Plantation Household: Black and White Women of the Old South, which targeted the differing experiences of Black enslaved women and White women during the antebellum period. Davis (1981) and FoxGenovese (1988) both argue that the lives of Black women were centered inside of the family units in their slave quarters, and their lives were shaped by male dominance over women. In addition, both authors expressed that Black women's experiences in a White dominant 
antebellum era differed from those of White women and enslaved Black men. For example, FoxGenovese (1988), argued that gender is accompanied by a set of social expectations for men and women. It was also noted that the privileged position of White women aligned them with feminine social roles which were denied to enslaved Black women (Fox-Genovese, 1988). It was also suggested that enslaved women suffered harsher punishments than slave men because of their experiences being raped and sexual exploited (Davis, 1981; Giddings, 1984). This was a painful aspect of slavery that enslaved men did not have to endure.

One condition all slaves shared was that their servitude and the servitude of their children were "lifelong" (Giddings, 1984). Legally, enslaved Black women were bound to the laws of the land and those who kept them in bondage and used them. Davis' (1981) book provides an extensive overview of Black women as slave laborers. Many female slaves were field workers alongside slave men while other enslaved women worked in their owners' homes and provided domestic labor for the mistresses and children (Davis, 1981). Historically, Black women have always "worked outside the home" (Davis, 1981, p. 5), because most of their days on plantations were spent in the fields or in their master's houses. Further, some enslaved Black females began their lifetime of work before adolescence. According to Steckel (1996), enslaved females performed various house duties and some plantation work during childhood. Slave reports show that plantation owners experienced higher production rates from female youth in the fields. These owners also noted that girls matured faster than boys because of their work ethic (Steckel, 1996).

Inside of the "Big House," enslaved women performed many domestic duties such as: taking care of her owner's children, cooking, cleaning, and sewing. Considering the theoretical framework for this study, Black Feminist Thought, Collins (2000) identified the "mammy" as 
one stereotype of Black women. Davis (1981) stated that the mammy was a stereotype that “presumes to capture the essence of the Black woman's role during slavery...[but] the reality is actually the diametrical opposite of the myth" (p. 5). Enslaved Black women were also subject to the same treatment as their male counterparts, including long hours of fieldwork.

\section{Havin’ Babies for Profit}

The exploitation of Black women's labor heightened when a ban was placed on the slave trade overseas (Davis, 1981). Unable to gather African people from other continents, enslaved women, also known as "breeders" (Davis, 1981; Giddings, 1984) became essential to the continued economic expansion of slave owners and their plantations. Women were praised for being able to produce multiple children for their owners (Davis, 1981). However, despite giving birth to their children, many Black women did not - in contrast to White women - reap the joys associated with motherhood. Davis (1981) stated,

in the eyes of slaveholders, enslaved women were not mothers at all; they were simply instruments guaranteeing the growth of the slave labor force...they were breeders animals whose monetary value could be precisely calculated in terms of their ability to multiply their numbers. (p. 7)

Here, Davis explicitly demonstrates that enslaved women's ability to produce children added to the burden they carried as free laborers and how plantation owners sexually exploited them for profit.

Pregnancy did not exempt enslaved women from hard labor; overseers expected them to perform their daily labor tasks in the fields (Davis, 1981). This caused them emotional pain given they were prevented from nursing their children and physical pain from being whipped if "they failed to fulfill their day's quota" (Davis, 1981, p. 9). However, not all pregnant enslaved 
women received harsh treatments. Giddings (1984) lamented that on some plantations, enslaved women were given extra clothes or more food to eat and other privileges, depending on the number of children she produced.

Giddings (1984) made a point that when enslaved women birthed children, that child inherited her status as a slave without regard to the status of the father. Giddings (1984) explained further, "such legislation laid women open to the most vicious exploitation...for a master could save the cost of buying new slaves by impregnating his own slave, or for that matter having anyone impregnate her" (p. 37). That slave master then had control over keeping or selling the child. Enslaved women had no legal right to their biological offspring. This reiterates Fox-Genovese (1988) and Davis' (1981) points that enslaved women were not privy to the social roles of motherhood for their own children, as White women were.

\section{Workin' for White Folks - Black Women After Emancipation}

While the Emancipation Proclamation and the $12^{\text {th }}$ amendment to the Constitution abolished slavery in the United States, Black women still worked in poor conditions, for White people. In the introduction of her book, To 'Joy My Freedom: Black Women's Lives and Labors After the Civil War, Hunter (1997) stated that, although Black women were ready to 'joy (enjoy) their freedom after Emancipation, the political climate of the South did not permit Black women to earn a living outside of domestic work. Hunter (1997) attested that in Atlanta, for example, a scarcity of jobs forced many former enslaved women to perform domestic work in homes. Black men worked in hotels and as industry workers, and manufacturing plants favored White women over Black women (Hunter, 1997). White families hired Black women to manage specific tasks in the home, and Black women often performed additional tasks for no extra money. Davis' (1981) research regarding Black women as domestic workers also identified that Black women 
often worked in the "lowest-paid" positions after Emancipation. Most of them were forced into housework and sharecropper positions. Black women and men, alike, often worked under the same conditions as during slavery, if they were incarcerated. Under the convict lease system, Davis (1981) posited that outside employers leased incarcerated Blacks to perform slave-like labor. The convict lease system made the state and employers wealthy (Davis, 1981) while profiting from Black imprisonment. Black women, specifically, could be sent to prison by simply rejecting the sexual advances of White men (Davis, 1981). This example further exemplifies how Black women's labor was exploited for the economic gain of Whites.

Interestingly, Davis' (1981) research contended that White women refused to do domestic work. Given domestic work was a normal responsibility for enslaved women, domestic work was generally assigned to Black women (Davis, 1981). Thus, for most of a century, Black women were obligated to domestic roles. Armstrong's (2012) study of Black women domestic workers, which focused on their lives during the Civil Rights Movement of the 1950s and 1960s, supports this claim. Domestic workers were essential to the survival of the Civil Rights Movement. They helped Movement participants protest and resist segregation laws in the South. Armstrong (2012) stated that many domestic workers participated in the Montgomery Bus Boycott, a boycott which lasted a year after the arrest of Rosa Parks in 1955 for refusing to give up her seat on the bus for a White person. One former Civil Rights Activist, former domestic worker, and participant in Armstrong's (2012) study explained that an employer of a domestic job terminated her because her boss found out she supported the Civil Rights activism in Montgomery. Armstrong's (2012) study found that women in the Movement were key players in mentoring other Black women of the time, "balancing work and personal life, and resisting racist structures" (p. 94). These were just a few of the many instances of Black women's resistance to 
systemic oppression.

As aforementioned, Black women did find ways to resist their unfair treatment in domestic life. Some women resigned from their posts due to low pay and cruelty from their employers (Hunter, 1997). Resigning gave Black women a sense of control over their lives and "an effective strategy to deprive employers of complete power over their labor" (Hunter, 1997, p. 28). Other Black domestic workers quit their jobs for opportunities to move around the country. While this was often a decision made to support their families, White people around the country believed quitting jobs was a "racial deficiency" found in Black people (Hunter, 1997). While White employers pushed the narrative of quitting being synonymous with Black culture, they issued Black Codes throughout the south. Some of the Black Codes "required employers to solicit recommendations from previous jobs in order to distinguish 'worth' or 'worthless' laborers" (Hunter, 1997, p. 29). This was to prevent frequent job changes.

This section of the chapter, labeled "Under His Eye" covered the explicit racist and sexist structures which kept Black women subjugated. White slave owners built their wealth on the backs of enslaved Black people and enslaved Black women were subject to the same extreme working conditions and abuse as their male counterparts. However, the economic and sexual exploitation of Black women was more harshly implemented than the abuse of Black men. Breeding became a necessity to continue the growth of the plantation owners' fortunes, and Black women suffered heinous sexual assaults at their hands. After Emancipation, limited jobs were available to Black women. White people believed domestic work was most fit for Black women because of their roles as domestic workers during slavery. Black women performed these jobs for little compensation. Given this, it can be determined that society and White dominance exploited Black women's labor for the benefit of White social, economic, and political gain. The 
next two sections discuss the educational system and the Women's Suffrage Movement, two arenas which played an integral role in both suppressing and empowering Black women.

\section{We Slipped and Learned to Read}

In an essay entitled "We Slipped and Learned to Read: Slave Accounts of the Literacy Process, 1830-1865," Cornelius (1999) brought to life the ways in which enslaved Blacks became literate in the antebellum South. The title of this section serves as an umbrella to operationalize significant Black women's entrances into the educational system and during higher education experiences. Black women are key players in the movement to academically advance members of their race. One of those women, Anna Julia Cooper, used much of her adult life to create educational opportunities for Black people.

Black women made noteworthy contributions to the higher education field (Choates, 2012); however, prior to their arrival in higher education, most states restricted enslaved Black people from becoming literate and attending school. It is understood that, historically, Black women were victims of sexist and racist structures (Davis, 1981). The educational system in this country is one extension of those structures. In this section, I provide an overview of the educational experiences of Black women in education. Using the standpoint social contract by Evans (2008), I discuss how Black women persisted in the educational spectrum despite the racist and sexist structures which were built to prohibit them from learning. One woman who exhibited tremendous efforts in the fight for an education is Anna Julia Cooper. Her contributions to the field and how she was an advocate for social change for Blacks in America is explained below.

Many slaves during the antebellum period learned to secretly read and write (Cornelius, 1999; Wolfman, 1997) with enslaved women as teachers. Learning how to read and write for 
slaves could have led to what Evans (2008) referred to as "violent reprisals", which considered reading and writing offenses that could be punishable by death. These consequences did not matter to many enslaved Blacks as they continued to meet for lessons when their masters were not present. Watkins (2001) posited that missionary abolitionists also assisted enslaved Blacks in their journeys to learn. Quakers and White missionary women helped create schools for Blacks in the North (Evans, 2008).

Black women are no strangers to teaching. Outside of the plantation, Black women were pertinent educators of not only Black children but White children in various parts of the country. For example, Celia Bell Davis, the only Black woman teacher in the Medary Avenue School in Columbus, Ohio lost her teaching position because White families did not want her teaching their children (Randolph, 2001). The White community had a fear of miscegenation and believed Black teachers were only qualified to teach Black children and that White teachers should teach White children. This incident with Celia Davis occurred after many White community members protested and petitioned against the racial integration of their schools in the district (Randolph, 2001). Randolph (2001) contested that Columbus was a growing city for Blacks in the late 1800s and early 1900s due to the migration of Blacks from the South. White community members threatened to form their own school if the school board did not remove Davis from Medar (Randolph, 2001). A year after the petition, the board removed Davis from her position. Randolph (2001) emphasized that racism and sexism caused Davis' termination. The community members deemed her the reason the "entire school district was suffering" (Randolph, 2001, p. 10). After Davis' removal, Columbus noticed a cultural shift in their schools as they segregated (Randolph, 2001). Davis was an example of a Black diversity worker because she tried to assist in educating both White and Black students, but the administration and community wanted her 
terminated. They used their power to remove her from her role despite her teaching qualifications.

Regardless of the issues in Columbus' K-12 schools, Oberlin College in Oberlin, Ohio was one of the few higher education institutions that opened its doors to Blacks and women in the late 1800s. Oberlin was one of a select few higher education institutions that awarded degrees to Black women. While this was a major win for the advancement of the education of Black women, Oberlin still followed segregated practices. For example, college administrators recommended Black women students to take more literary courses ("ladies courses") and male students enrolled in courses which were required of bachelor's degrees (Evans, 2008). Lucy Stanton was the first Black woman to receive a literary degree in 1850, and Mary Jane Patterson was the first Black woman to receive a bachelor's degree in 1862.

As more Black women matriculated into higher education, southern states experienced slight increases in the number of Black women graduates. Evans (2008) attributed this to two separate instances. First, states adhered to the separate but equal doctrine of Plessy v. Ferguson. This Supreme Court case breathed life into Jim Crow segregation and because of this, predominantly White institutions did not have to grant the same education access to Blacks as they did Whites. The second instance was the rise of Historically Black Colleges and Universities (HBCUs), when their doors opened for the educational advancement of Black students. Black students chose to attend HBCUs when PWIs did not welcome them (Evans, 2008). While HBCUs experienced an influx of Black women and students, these schools still suffered from underfunding and the lack of resources from their states, unlike White schools.

The lack of resources and segregated schools were not the only demonstration of White supremist ideology which HBCUs experienced. The Hampton Institute, also known as the 
Hampton Model, declared that Blacks should be educated to become teachers who would graduate and teach other Blacks in their communities (Anderson, 1988). However, this concept was not without condition. Founder Samuel Chapman Armstrong "developed a pedagogy and ideology...to maintain within the South a social consensus that did not challenge traditional inequalities of wealth and power" (Anderson, 1988, p. 33). In other words, the premise of the Hampton Model was to educate students regarding how to teach Blacks the importance of labor, to not interfere with the current establishment of wealth held by White people.

Three notable HBCUs for Black women were established in the late 1800s: Spelman Seminary, Bennett College, and Hartshorn Memorial College (Evans, 2008). These schools were pillars in educating Black women in America. These institutions received support from various religious affiliations and centers to craft what Evans (2008) declared the "ideal phenomenal woman who was educated and dedicated to racial uplift" (p. 46). Interestingly, Black women have always carried the burden to uplift their race as they matriculate through the educational system. For example, Hylton (2012), who cited Noble (1993), lamented that Black women's educational journeys are important to the children in their community and "racial uplift." Black women found that teaching members of their community was the avenue which caused Black success.

Evans' (2008) standpoint social contract theory is an extension of Rousseau's Social Contract, Carol Pateman's Sexual Contract, and Charles Mills' Racial Contract. Rousseau's social contract states that those who live give up their "natural freedom" for certain civil and social freedoms that are protected by the state and "adhere to some degree of the dominant's authority in exchange for agreed upon benefits" (Neiman, 2013, p. 27). Pateman's sexual contract argues that the social contract is one of male domination and neglects 
to mention how women are subjected to the rule and sexual desires of men (Pateman, 1988). Mills' (1997) racial contract outlines the historical concepts of white domination over nonWhites and how non-Whites are subject to violence and social control. Evans (2008) developed the standpoint social contract theory to demonstrate how Black women's race and sex intersect at the social, sexual, and racial contract. Standpoint social contract theory posits that the writers of the U.S. Constitution (a contract) placed Black women in a position to be uneducated servants, (Evans, 2008) and that their lives were a "standpoint" of shared experiences and that "common in their experience was their relation to this contract that excluded all Black women from political participation and social equity (p. 5). Further, Evans (2008) said that the use of social contract is an,

'act of association.' In this history, I uncover evidence that African American women, especially those who entered the academy, attempted to fully participate in defining the national and international 'common will.' This record of Black women's educational attainment refutes interpretations that portray them solely as objectified victims. Rather, I find that these historical narratives demonstrate that Black women have crafted a social contract that exposes a contested relationship between individuals and public institutions, where Black women have engaged in defining and determining their roles, even within oppressive structures. (p. 5)

Black women are not solely poor, or solely a woman, or solely Black. They are often all three, and their experiences generally stem from the intersection of these identities. The social standpoint highlights the nuances of their experiences. Black women and especially Black women in academe, such as Anna Julia Cooper, define their own lives amid systems that kept them in submission and silenced. The standpoint social contract theory, as Evans (2008) stated, 
allows Black women to have "agency" in the face of oppression.

\section{Anna Julia Cooper}

Researchers such as Garner (2004), Hylton (2012), and Evans (2008) paid homage to the life and educational contributions of Anna Julia Cooper. Cooper was a prominent figure in the educational advancement of Black people in America. The year of Cooper's birth is unknown (Garner, 2004), but she was born in Raleigh, North Carolina. Cooper began her journey in education at St. Augustine's Normal School and in 1881, she attended Oberlin College (Garner, 2004). During college, she participated in programs geared towards women's initiatives and teaching. After receiving her Bachelor of Arts degree, Cooper became a principal in Washington, D.C. at a colored high school and taught at many high schools and colleges (Garner, 2004). Oberlin awarded her a Master of Arts in mathematics in 1887 and by 1906, she had to end her career as a principal because "White members of the District of Columbia board of education joined together in the conspiracy to ruin Cooper's reputation" (Garner, 2004, p. 18). After the scandal, she received her Ph.D. and Garner (2004) noted her as the first Black woman in D.C. to have a Ph.D.

Cooper's philosophy of teaching focused on "community." Evans (2008) stated that Cooper believed teaching was a responsibility to the community and to parents. She worked with families during times of tragedy to understand how to best serve the students at her schools. She was a social justice advocate for students and debunked the notion that schools were the sole cause of students' lack of performance (Evans, 2008). She understood that "what severely impacted students' abilities to learn was a combination of the inequities of the larger social order in conjunction with schools that parted ways with the surrounding communities" (Evans, 2008, p. 162). Social structures and racial cruelty were the realities of many Black families with 
children in the educational system. Cooper interestingly believed that segregated schools aided in racial inferiority (Evans, 2008), and although she understood the benefits of having them, she felt keeping schools segregated was “wrong” (p. 167). She understood the impact it had on students' performance in the classroom.

Cooper spent her life working to educate members of her community. Her legacy is a mirror to the work many Black women perform in higher education today, and they do it because they desire to help others. She advocated for Blacks and women to earn an education for a better life for themselves in the face of racism and discrimination in the educational system.

The research regarding Black women's experiences in education in relation to Black women's experiences today at predominantly White institutions highlights the social burden that Black women currently face while matriculating through the educational system. This research also demonstrates that, historically, education struggled with diversity and that Black women were and are "outsiders within" (Collins, 1986, p. 514) the racist and sexist structure of education. Overall, the oppression Black women faced was a key tool to keep them ignorant and subservient and, therefore, easier to control. Moving from educational control to social and political control, the next section titled Ain't I a Woman? highlights how Black women were excluded in the movement for women's rights and suffrage.

\section{Ain't I a Woman?}

The Anti-Slavery Movement gave birth to the Women's Suffrage Movement (Davis, 1981). However, White women's desire for the ballot failed to acknowledge Black women in their efforts. This section entitled “Ain’t I a Woman?,” discusses how Black women were neglected during this crucial time in political history. Sojourner Truth, a former enslaved woman, delivered her famous “Ain’t I a Woman?” speech at a convention for women's voting rights in 
1851 (Davis, 1981). It explicitly called attention to Black women who were blatantly ignored in the conversations regarding women's rights.

While slavery, domestic work, and education for Black women demonstrated the political and economic domination of White supremacy over Black lives, these were not the only ways in which Black women in America experienced oppression based on their race, gender, and class. The Women's Suffrage Movement was a social movement in the U.S. that began as an AntiSlavery campaign and, thereafter, turned into White women's self-serving desire for the ballot. Their ambition to push back against the patriarchal oppression they faced in the home and politically, allowed them to steer away from fighting for equal rights for Blacks and Black women.

The birth of women's rights, according to Davis (1981), began with the Anti-Slavery Movement of the mid-1800s. White and Black abolitionists, who believed in the liberation of Black people in America, led anti-slavery campaigns and conventions. After abolitionist, William Lloyd Garrison, released the Liberator in 1833, the country saw working class White women rally behind the anti-slavery movement (Davis, 1981). However, wealthy White women (the White bourgeoisie) were also in the midst of campaigning for the freedom of enslaved Blacks. Davis (1981) equated wealthy White women's desire for Black liberation to their desire for liberation between the sexes. Many middle-class White women during this time opposed their statuses as housewives. Women were most highlighted for their home-servitude in the eyes of the American middle class. As women advocated for the rights of Blacks, they believed their status as housewives and as working-class women equated to the conditions of slavery (Davis, 1981). There were four women permitted to attend the first Anti-Slavery Convention in 1833 as "listeners and spectators" (Davis, 1981). While the attendees of the convention were there for the 
same cause, this male dominated space was unsupportive of women contributing to the decisions made at the convention. This opposition did not stop women from speaking up. During the campaign for the freedom of enslaved Blacks, White women recognized their oppression in a patriarchal and sexist society. According to Davis (1981), White women's fight for the freedom of slaves gave them a voice and an understanding that the political arena was the only way to push back against the oppression they faced in their homes.

Elizabeth Cady Stanton, a prominent figure of the Women's Suffrage Movement, helped coordinate the Seneca Falls Convention of 1848 which gathered people to discuss women's rights. One major topic of discussion was women's right to vote and, while many opposed the idea, Frederick Douglass advocated for women's right to the ballot (Davis, 1981). Free Black women were among the outsiders who also had an interest in the ballot and women's rights (Davis, 1981; Giddings, 1984). Interestingly, Davis (1981) lamented that Black women's presence at women's rights campaigns was a symbol of their desire to "be free from racist oppression but also from sexist domination" (p. 60). Here, Davis (1981) highlighted Black women's intersectional experiences.

One Black woman who spoke on multiple occasions about the intersectionality of Black women's struggles was Sojourner Truth. During debates with men and women about whether women should have the right to vote at a convention in Ohio in 1951, Truth delivered her famous Ain't I a Woman? speech (Davis, 1981). The debates about women's suffrage stemmed from one-sided sexist ideals which declared that women were weaker than men (Davis, 1981). Truth's speech highlighted the hypocrisy of considering womanhood as solely applicable to White women. As a Black woman, Truth and other Black women were subjects of abuse and other forms of oppression based on their race, class, and sex. Davis (1981) eloquently concluded that 
Truth,

exposed the class-bias and racism of the new women's movement. All women were not White, and all women did not enjoy the material comfort of the middle classes and the bourgeoisie. Sojourner Truth herself was Black - she was an ex-slave- but she was no less a woman than any woman at the convention. That her race and her economic condition were different from theirs did not annul her womanhood. (p. 64)

While Truth's powerful speech filled some of the convention goers with pride, that did not stop many White women from opposing Truth speaking at the second day of the convention (Davis, 1981).

Black women's drive for women's rights and suffrage did not end with Truth. Giddings (1984) presented three reasons regarding why Black women wanted the right to vote. The first was their sexual exploitation. As aforementioned in the literature review, Black women's sexuality has been historically subjected to oppressive ideals and stereotypes (Collins, 2000). Black women suffragists believed their right to vote would afford them agency in their own "virtue", and voting would tear down the barriers to interracial marriage, which was "aimed at Black women's degradation and exploitation" (Giddings, 1984, p. 121). The second reason Black women wanted to vote was to advance education by improving the condition of the school systems for Blacks. Lastly, the vote would offer Black women workers job security (Giddings, 1984).

The right to vote was vital for Black women. Giddings (1984) posited that when Black women who fought for the voting cause heard that Black men were releasing their own right to vote, Black women were irate. Black women deemed that if Black men relinquished their rights, they were dishonoring their race (Davis, 1981; Giddings, 1984). Giving Black women the right 
to vote would help uplift Black racial advancement efforts. White politicians were boisterous in their opposition of Black women voting, and they cited that Black women are more aggressive than Black men, and Black women would bring furious energy to the polls (Giddings, 1984).

Women's suffrage frontrunners, Elizabeth Cady Stanton and Susan B. Anthony, were infamous for their racist ideals about women's rights and suffrage. Susan B. Anthony is often quoted as saying "I will cut off this right arm of mine before I will ever work or demand the ballot for the Negro and not the woman" (Wesleyan University, n.d.). White women's aspirations for the right to vote was self-serving and their way of upholding White supremacist ideals (Giddings, 1984). Anthony and Stanton's push for women's rights was to help advance their race to keep Whites in power (Davis, 1981; Giddings, 1984). While Anthony worked with Black women like Ida B. Wells to discuss issues about women's rights, White women's rights were the only ones included in Anthony's Expediency Plan (Giddings, 1984). The Expediency Plan, in short, outlined that "the female franchise was a panacea to the Nation's ills" (Giddings, 1984, p. 125) and the ballot needed to be supported so White women could start the "curing" process for the country. Although Black women shared the experience of being a woman with White women, they did not share the same racial identity, which excluded Black women from the expediency plan.

Still, Black women advocated for themselves during the time they were marginalized. Ida B. Wells, a social advocate of the anti-lynching campaign, helped form the Alpha Suffrage Club in Chicago for Black women (Giddings, 1984; Wesleyan University, n.d.). The National Association of Colored Women also created a subsection of their organization to educate Black women about voting (Davis, 1981). The fight for women's rights and suffrage was a social movement rooted in White supremacy. White women suffragists pushed for the ballot to help 
advance the White race in America while blatantly ignoring Blacks and Black women's rights to the polls. Black women were in a unique position as they too were, historically, victims of sexual exploitation and oppression based on their sex. However, they were also subjected to racial discrimination because they were Black. Using their privileged racial status, White women dismissed the urgency to advocate for Blacks as they fought for equality among the sexes.

The last section discusses conversations regarding the experiences of Black women in Student Affairs and how the previous historical, political, social, and economical factors still play a significant role in Black women's lives. West (2017) lamented that we have to understand Black women's past struggles with racist and sexist structures to understand their experiences in academe. The last section, entitled “Anna's Daughters," explores how Black women in higher education have navigated their "outsider within" status.

\section{Anna's Daughters}

In this section, I operationalize the status of Black women in the student affairs field and their experiences as administrators and Student Affairs professionals. Much of the research regarding Black women in higher education has given special attention to the experiences of Black women faculty members (Mabokela \& Green, 2001; Robinson, 2018; Watkins, 2018; Williams, 2012; Wilson, 1998). While Black women Student Affairs administrators often experience similar issues regarding their race and sex, the difference between Black women faculty and Black women administrators is that most tenure-track faculty members have the protection and job security of tenure, whereas Black women administrators do not. Further, research regarding Black women Student Affairs professionals has been limited (Henry, 2010; West, 2011). The dearth of research is surprising because, as West (2011) and Glover (2012) noted, Black women Student Affairs professionals have had a significant impact on the lives of 
students.

Lucy Diggs Slowe was the first dean of women at Howard University. According to West (2011), dean of women positions were the first roles Black women had in Student Affairs. Dean of women positions supported and developed college women (West, 2011). To support the growing number of deans of women, the National Association of Deans of Women and Advisors of Girls in Colored Schools (DOWA) was created in 1929 (West, 2011). Soon after, DOWA merged with the National Association of Personnel Deans of Men in Negro Educational Institutions (DOMA) to form the National Association of Personnel Workers in 1954. West (2011) continued to say that in the 1950s, "following World War II the number of these positions decreased, and eventually the position disappeared. This was due to the fact that large numbers of [White] men returned home from the war and assumed these positions" (p.45). Black women were then removed from these roles.

Today, Black women are more concentrated in Student Affairs administrator roles (approximately 11\%) versus faculty (approximately 2\%) (NCES, 2016). Student Affairs work in higher education calls for professionals to assist students with their experiences outside of the classroom. These administrators aid in student development and help them make meaning of their "social identities" (Wesley, 2017). In Belk's (2006) study, she posited that Black women were likely to be in these positions at small 4-year institutions.

Wesley's (2017) qualitative dissertation articulated how her participants' race and sex played a role in their careers as Student Affairs professionals. Her participants felt they experienced opposition in their work based on their dual identities. These challenges included feeling undervalued (Wesley, 2017). They also identified that mentoring was necessary to advance their careers. 
Wesley's (2017) study highlighted one phenomenon in Black women's experiences which was the need for mentorship. Researchers identified this need as a topic worth studying for this group of people (Burke \& Carter, 2015; Jones \& Durfor, 2012; Moss, 2014; Wiggins, 2017) because a lack of mentors can hinder career advancement. One reason why Black women Student Affairs professionals lack mentorship is because of their status as an oppressed people (Wiggins, 2017). In other words, in predominantly White environments, White people are more likely to advance in their career because they have access to individuals who help them up the ladder, whereas Black women have to work harder to determine how to advance to their next step (Jackson \& Dorsey, 2009; Wiggins, 2017).

Using a mixed methods approach, Burke and Carter (2015) researched networking opportunities for Black women's career advancement. They surveyed 60 Black women and found that, although mentoring and networking was something in which their participants engaged, they still felt that barriers to their advancement was attributed to their race and sex. Moss (2014) interviewed 13 Black women community college administrators and found that the participants' White colleagues had stereotypical perceptions of them and did not believe Black women could hold mid-level positions. Interestingly, prior to Moss' (2014) study, Powell's (2008) participants mentioned that their White colleagues were "surprised" that there were Black women in leadership roles.

In addition to career advancement, Sobers (2014) found that her participants struggled to get compensated for the work they did. The wage gap in America was still an issue. When considering intersectionality, Black women's race and gender are subject to potential discrimination at the time of the job offer. Black women earn between " 62 cents to every dollar paid to white, non-Hispanic men" (National Partnership for Women and Families, 2018, para 2). 
Sobers' (2014) participants said they were not offered competitive compensation packages when they received their job offers. The participants also believed they performed multiple tasks in their roles and were not compensated for them. When salaries became public knowledge, many of her participants noticed their White colleagues made more money than they did in the same job roles (Sobers, 2014). Being asked to perform multiple tasks for small salaries relates to Black women being economically exploited during slavery and as domestic workers.

Despite the barriers they face, Black women have coped and persisted in their environments (Johnson, 2016; Powell, 2008; Sobers, 2014). Coping strategies include using support systems, self-motivation and determination, and spirituality (Jackson \& Dorsey, 2009; Sobers, 2014; Wesley, 2018). Coping and persistence are not unusual practices for Black women in oppressive environments. Anna Julia Cooper persisted in her educational career despite the pushback she received from Whites. Enslaved Black women and Black women domestic workers also found ways to cope during times of turmoil.

\section{Theoretical Framework - Black Feminist Thought}

Black Feminist Thought (BFT) demonstrates that, despite the dominant systems' attempts to oppress Black women, Black women are instrumental in crafting their own definitions of who they are and resist racist and sexist structures. BFT is applicable to my study regarding Black women because it provides context to the unique experiences Black women have had as workers and educators.

In her book, Black Feminist Thought: Knowledge, Consciousness, and the Politics of Empowerment, scholar Patricia Hill Collins (2000) identified that White male social dominance and control have historically monopolized the experiences of Black women. This control denied Black women access to education and resources (Collins, 2000). In this structure, Black 
women's thoughts and knowledge are suppressed for the political gain of White dominance and social control. Black Feminist Thought (BFT) allows Black women to reclaim their voice and tell their own stories to define who they are and their place in society (Collins, 2000). Further, Collins (2000) said "this dialectic of oppression and activism, the tension between the suppression of African American women's ideas and our intellectual activism in the face of that suppression, constitutes the politics of U.S. Black feminist thought” (p. 3). Black women's experiences are the ideals which shape their reality and the way they tell their stories.

Collins (2000) posited that suppressing the thoughts of Black women is a tactic of dominant systems and is not only salient to America society but is present in areas such as Europe, Africa, and the Caribbean. Vocalization against oppressive systems has been a form of activism for Black women for years, championed by women such as Sojourner Truth and Toni Morrison (Collins, 2000). It is important to understand how activism and oppression work in a system that has been historically designed to omit the voices of Black women.

Understanding Black women's historic position in America is key to understanding BFT. The Atlantic Slave Trade brought Black women to America to work to build the economy for Whites. The oppression experienced by these enslaved women have shaped the stories of Black families, jobs, and Black women scholars today (Collins, 2000). Hence, Collins (2000) operationalized three "interdependent dimensions" of these women's oppression. The first dimension is the exploitation of Black women's labor in the U.S. Collins (2000) said that this dimension highlights Black women's "role" as servants and the "economic dimension of oppression" (Collins, 2000, p. 4). The second dimension is political which shut us out of key areas such as the right to vote. One of the major systems which kept Black women silenced is the educational system that Collins (2000) described as underfunded and segregated. This 
disproportionate educational system aided in Black women's struggle with literacy and retention in school. The third dimension is ideological. Collins (2000) defined this as controlling images that were developed during slavery for the oppression of Black women. White dominance played an integral part in the racist and sexist ideologies that shape our worldview of Black women and Black womanhood. These stereotypes include: the mammy, the jezebel, and the sapphire as labels that oppress us in the larger context (Collins, 2000).

Collins (2000) posited that BFT is a concept which allows Black women to create their own consciousness as White feminist ideologies have historically excluded them. She noted that previous feminist theories try to outline the experiences of all women but, in reality, they cater to White middle-class women (Collins, 2000). These exclusions aid in Black women's “outsider within" status (Collins, 1986). An outsider within describes feelings of isolation when in predominantly White spaces and that these spaces prevent Black women from "becoming full insiders" (Collins, 2000). Explained further, Collins (2000) placed outsider within in the context of Black women working in White homes. She said that though White people "loved" their Black maid, Black women were still not a part of their family. Therefore, Black women were the outsiders in their workspaces. For Black women to become "insiders", they need to conform to the ideals of the dominant White male culture (Collins, 1986). Given society was not shaped and designed for Black women, assimilating is not possible.

BFT is important to my study regarding Black women in higher education diversity roles because it helps tell the unique stories of my Black women participants in the context of the White structures within which the work. BFT allows us to reclaim our purpose and "rediscover, reinterpret, and analyze the ideas of subgroups within the larger collectivity of U.S. Black women who have been silenced" (Collins, 2000, p. 13). Considering this, Black women diversity 
workers have been under researched, and my study highlighted their voices within the larger research platform regarding Black women Student Affairs professionals.

Black Feminist Thought was the theoretical framework used to formulate my research questions and the lens through which I analyzed the data collected from my participants. It is important to understand the ties BFT has to critical theory. Critical theory addresses "issues of power and domination and advocates understanding from the perspective of the exploited and oppressed" (Glesne, 2011, p. 10). Here we see that BFT provides an avenue for Black women as historically marginalized people, to push back against systems that oppress them. This was key for telling the stories of the participants in my study. Choates (2012) attested that BFT was a crucial component to analyze the data collected from her Black women participants because it showed the "social dilemmas of race and gender for Black women...in higher education" (p. 39). This was a similar experience during the interview process with my participants.

\section{Conclusion}

In this section, I present research regarding multiple experiences Black women have had which help place the historical, cultural, and social context of this study. The research demonstrates that, although Black women have made tremendous strides in the field of higher education, their experiences have not changed as drastically. Many Black women face racism and sexism in predominantly White spaces and are subjected to being overworked for no additional compensation. However, the research fails to highlight the experiences of Black women who work in diversity roles. My research sought to fill the gap in the existing literature by offering tangible ways that higher education institutions can work to support the women in these roles. Further, research regarding Black women in diversity roles is also important because of their status as people of color and women, doing diversity work on a White campus. Ahmed 
(2012) stated, "there are problems and pitfalls of becoming a diversity person of color...you already embody diversity by providing an institution of whiteness with color" (p. 4). Given this understanding, my study sought to identify what these women's experiences are and how they affect their ability to perform the daily responsibilities of their jobs.

The following methodology chapter describes the type of study, the research participants, the study design, and the collected data. It also discusses the steps taken to assure the trustworthiness and validity of the study. Finally, it concludes with an outline of potential ethical issues and how I planned to ensure the safety of my research participants. 


\section{CHAPTER III: METHODOLOGY - WHAT ARE WE DOING?}

In this chapter, I explain the methodological approach used in my research study. The purpose of this study was to investigate the experiences of Black women who work in diversity related positions at predominantly White institutions (PWI). Research shows that Black women professionals in higher education have varying experiences regarding their race and gender (Choates, 2012; Collins, 2000). It is important to research these experiences for Black women professionals because they are often hired to do diversity work but can be victims of the very issue they were hired to solve. More specifically, I addressed the following questions in this study:

1. What are the experiences of Black women professionals who work in diversity positions? What aspects of their roles influence those experiences?

2. How do these experiences affect Black women's ability to perform the daily tasks of their roles?

3. What strategies do these women utilize to effectively perform their job responsibilities?

4. What can colleges and universities do to improve the work environments for Black women serving in diversity roles?

For this study, diversity roles were operationalized as those undertaken in housing and residence life and in multicultural affairs departments and centers. I was specifically interested in exploring the experiences of Black women employed full-time in housing and residence life and multicultural affairs departments and centers at PWIs. In this chapter, I briefly explain Black feminist epistemology as my research paradigm, the type of study conducted, and the method used for collecting data. Then, I describe my study participants and why I chose these women to share their stories for my research. This section is followed by a detailed description of how I 
analyzed the data collected from the participants. Lastly, I explain the validity and trustworthiness of my study and implications for higher education administrators. The aforementioned Black Feminist Thought theory is what guided this research methodology to better explain the experiences of Black women in diversity roles at PWIs.

\section{Research Paradigm -Black Feminist Epistemology}

Feminism is a term that has been difficult to define (hooks, 2015a), but its historical roots stem from White middle-class women's idea that all women share similar experiences in a sexist society (hooks, 2015a). However, White women cannot account for the racism and classism that Black women experience in a patriarchal society (hooks, 2015a). The term feminism is an umbrella term to describe the experiences of all women under sexist structures in the United States; however, White bourgeoisie women have centered the feminist movement on issues that seemingly benefitted them and marginalized women who did not inhabit their White middle class characteristics (hooks, 2015a). Black women, one of the groups who has historically been pushed to the margins of the feminist conversations and activism, are key contributors to feminist ideologies. Collins (2000) posited that oppression in various forms has played an active role in Black women's lives and has suppressed their thoughts and knowledge for political gain and White dominance. An example of this is the Women's Suffrage Movement, mentioned in the literature review. White middle-class women led the movement and ignored the experiences of Black women during that era. A Black feminist voice or approach to this proposed study is key to telling the stories of Black women professionals, especially those who work in diversity roles. Recognizing that Black feminist perspectives are essential to telling the stories of Black women, I employed this theory into my qualitative research regarding Black women in diversity roles. It is important to note that Black Feminist Thought is the theoretical way of explaining 
Black feminism. It gives voice to the voiceless. Black Feminist Thought, as a framework, situates Black women in the historical context of how they have been subjugated and victims of racism and sexism in the United States. Black feminist epistemology (Black women's ways of knowing) provides an outlet to "rethink the particular matrix of domination that characterizes U.S. society" (Collins, 2000, p. 228). In this study, the matrix of domination is qualitative research. Black Feminist Thought and Black feminist epistemology were key tools which guided the way I posed my research questions and analyzed the data. As a methodology, Evans-Winters (2019) stated that Black feminism has been overlooked and devalued by traditional White scholars. There are a number of reasons why Black women's contributions have been silenced in qualitative research. These reasons include "scholars not knowing or willing to acknowledge Black people as scientists and theorists, lack of awareness of Black women as producers of knowledge, and a tradition of racial and gender exclusion in the academy" (Evans-Winters, 2019, p. 17). Qualitative research has historically placed Black women in the margins.

White qualitative researchers often forget that Black women's epistemologies are not in singular form. Our understanding of life derives from the world around us and the intersection of our race, class, and gender "take precedence over the common experience women share" (hooks, 2000, p. 4).

Another reason why incorporating Black feminism into qualitative research is important is because it provides an opportunity for researchers to dissect the nuanced experiences of women from marginalized communities (Evans-Winters, 2019). Further, Black feminism provides qualitative research with an "oppositional gaze" (hooks, 1992, p. 116) which, as operationalized by bell hooks, is the way we as marginalized people stare domination and oppression in the face and provide alternative ways of thinking that challenge social norms. In 
this study, it was my hope that the participants' stories as well as my own will allow us to "not only stare" [at qualitative research] but for our looks to "change the reality" [of qualitative research] (hooks, 1992, p. 116). I also anticipated it changing the reality of some predominantly White institutions.

There are many ways in which Black women "know" what we know. Our knowledge derives from experiential knowledge, conversations with other Black women, interdisciplinary reading, storytelling, narratives, cultural intuition, and a host of other factors. Experiential knowledge means that we as Black women "know things" because we have experienced it. Scholars such as Evans-Winters (2019) and Hodges and Welch (2017) wrote about their experiences as Black women in various environments (e.g., work, family life, or school) and how they navigated those spaces. Interdisciplinary reading means we span our reading across the disciplines and reexamine past literary works to understand Black women's experiences (Collins, 2000). Evans-Winters (2019) posited that formal research follows a traditional set of methodological rules, but as Black women, we often rely on our cultural intuition which stems from the experiences we had as children and as adults.

\section{Qualitative Research}

Qualitative research, according to Sobers (2014) encourages participants to describe their experiences in their own words. As a Black woman who works in the diversity field of higher education, I believe it is important for our voices to be heard and our stories to be told in our own words. MacPhearson (2011) said, "Qualitative researchers strive to enhance an understanding of human conduct by capturing how people construct and describe the meanings they make" (p. 64). The role of Black women doing diversity work and the meaning they make from their experiences have not been as thoroughly explored as the work of Black women administrators 
and faculty members. Black women in diversity roles face the challenge of educating others about diversity and inclusion while navigating through hostile environments directed towards them. A qualitative study allowed these stories to be told and allowed them to critically challenge predominantly White institutional leaders in efforts to create safer environments for Black women in these positions.

\section{Cultural Narrative Study}

In her book, How We Get Free: Black Feminism and the Combahee River Collective, Taylor (2017) interviewed the writers of the Combahee River Collective (CRC) and the founders of \#BlackLivesMatter. In the 1970s, the CRC wrote a statement that highlighted the unique experiences of Black women in America. Coining the term "identity politics," the CRC recognized that Black women's experiences as an oppressed group "shaped their political outlook" (Taylor, 2017, p. 139). Their statement also identified how classism played a key role in Black women's lives as there was a gap between upper-class Black women and poor Black women (Taylor, 2017). Taylor's (2017) use of interviews integrates the message of the CRC's Statement into the original writer's current life and serves as a connecting foundation to the founders of \#BlackLivesMatter ideals about Black feminism. The interviewees utilized storytelling to explain their experiences to Taylor, the researcher (Taylor, 2017). Storytelling is one technique of narrative inquiry. The stories elicited in my study included the interviewees' experiences, information about how race and gender impacted those experiences, and anything else they wanted to share with me.

I used a narrative based qualitative research study to tell the stories of my participants experiences. According to Gupton (2014), cultural narratives "are personal stories through which people come to understand their identity, their social location, and other agents" (p. 52). These 
stories allow participants to unpack their realities, determine how those realities influence their work and how they navigate predominantly White spaces. Allowing narrative inquiry to guide this study enabled me to answer the research questions, which focused on the experiences of Black women in diversity roles in higher education and how they might be better supported as they perform their work at PWIs.

Evans-Winters (2019) further explained the importance of narrative inquiry. Personal storytelling and narrative allow Black women to "construct and legitimize claims that serve to portray our shared socio-political experiences" (Evans-Winters, 2019, p. 22). In other words, the stories we tell, in our own unique voices, to understand what is happening around us, makes us credible contenders to be qualitative researchers. Further, Evans-Winters (2019) posited that narrative inquiry "humanizes" Black women in research and centers them in a world that tries to “dehumanize" them (p. 23).

This paradigm was best suited for my qualitative research because the voices of my participants will challenge the systems of dominance in which they work. Black women have historically been oppressed, and understanding their experiences is pertinent to transforming a system that was not set up for them to be successful. Therefore, I wanted to explore what Black women diversity professionals experience at predominantly White institutions. Glesne (2011) called this praxis, "the relationship between thought and action, theory and practice" (p. 10). These narratives hope to inform higher education practice.

\section{Data Collection}

To develop a complete view of Black women's experiences, my data collection method consisted of a one-on-one, semi-structured, one-hour interview with each participant. In a semistructured interview, according to Glesne (2011), "questions emerge in the course of 
interviewing and may add to or replace pre-established ones" (p. 102). All interviews were conducted using the Zoom video platform because the women in the study were located in various states within the United States of America. During the interviews, I asked each participant questions about their upbringing, employment history as it relates to their decision to do diversity work full-time, their job descriptions, and the responsibilities they have in their roles. (See Appendix B for a detailed list of questions). Because the interviews were semistructured, more questions developed from our conversation. According to Choates (2012), interviewing is beneficial for a qualitative study because it provides an opportunity to thoroughly outline women's experiences. She also said that because Black women have historically been oppressed, interviews allow "oppressed people to resist white oppression by identifying themselves, naming their history, and telling their stories" (Choates, 2012, p. 47). The participants in my study shared their stories about their environments at their respective predominantly White institutions.

\section{Participant and Site Selection}

I recruited participants by utilizing the Facebook group titled Black Student Affairs Professionals (BLKSAP). This was a purposeful selection. According to Campbell (2014), a purposeful selection is the optimal approach for recruiting participants who directly fit the group one wants to study. Accordingly, I searched for participants who have worked in a diversity related role for one or more years at predominantly White colleges or universities. These participants included those who are currently employed in diversity roles in housing and residence life and multicultural centers affairs departments or centers or who have done this work in the past for one year or more. The women also had to be 18 years or older and identify as Black women. 
To eliminate bias, I did not interview women with whom I had a prior relationship. I do not know most of the women in the BLKSAP Facebook group. Currently, there are 10,434 members in the group. In the past, BLKSAP granted me opportunities to connect with a few people from across the higher education field for resources regarding jobs, help with a class assignment, and hiring facilitators for training on my campus. Given BLKSAP is a supportive space for Black professionals, I was confident this space could be used as an avenue to recruit Black women in diversity roles. When members see posts, they often tag people in posts whom they feel will be beneficial resources for studies.

In addition to using this social media platform, I relied on snowball participant selection. Campbell (2014) defined snowball sampling as "the method by which initial sample respondents recruit or recommend other individuals who may have similar characteristics or experiences that can be deemed useful to the topic" (p. 59). The research participants I recruited through BLKSAP provided me the contact information of other women they believed best fit the criteria for my study. Snowballing was an effective strategy for enlarging the pool of potential study subjects.

To protect the participants' confidentiality, I created a Microsoft form and posted it on the BLKSAP site for Black women to complete. I then contacted them based on their information in the form regarding participating in my study. The form included basic information such as name, institution, job title, email, and phone number. After I identified my participants, I contacted them to complete a consent form and discuss their interview times. At the conclusion of the recruitment process and from using the snowball method, I confirmed 11 participants for my study. 


\section{Data Analysis}

Creswell and Creswell (2018) compared the data analysis process to "peeling back the layers of an onion" (p. 190) because of the complexity of taking apart the data. I analyzed the data while I interviewed participants. While I listened and took notes during each interview, I wrote small cues to myself if one of the participants said something that was similar to what another participant said. Creswell and Creswell (2018) stated that this memo writing technique could be used "as narrative in the final report" (p. 192). I made sure to write out the similarities and differences in Chapter Four. Glesne (2011) noted the importance of memo writing, as well. Memo writing is crucial for researchers while they are still in the data collection process. While observing, researchers should take notes regarding their feelings in the moment or thoughts they may have that are important to reflect on at a later point in time. It is important to write or record thoughts in the moment because "if you wait until the end to write, your data work will not be as rich, thorough, and complex" (Glesne, 2011, p. 189). I took this advice, so I did not lose out on important information that benefitted my study.

Once I completed the interviews, I transcribed them, coded them, and I listened to the interviews and read the transcripts while I listened (Sobers, 2014). This strategy ensured that I did not misinterpret something the participants said during the interview. I matched each response with the corresponding interview question. A practice that Sobers (2014) mentioned was to "reflect generalities" during the analysis process and to write down those generalities on the transcript (p. 76). Generalities are the ways I projected my experiences onto the experiences of my participants.

I analyzed my data using thematic analysis and referred to my theoretical framework of Black Feminist Thought. According to Maguire and Delahunt (2017), thematic analysis is "the 
process of identifying patterns or themes within qualitative data". In other words, it looks for "patterns in the data that are important or interesting and use these themes to address the research or say something about an issue" (p. 3352-3353). In the same article, Maguire and Delahunt (2017) cited Braun and Clarke's (2006) six-step framework for coding:

1. Become familiar with the data

2. Generate initial codes

3. Search for themes

4. Review themes

5. Define themes

6. Write Up. (Maguire \& Delahunt, 2017, p. 3354)

I used this six-step framework to help me code and develop themes for my data. The themes helped me find my participants' collective voice (Collins, 2000).

During this process, I read each transcript and searched for similar phrases or conversation themes among them (become familiar with the data). Once I identified a common theme, I categorized each code in a chart created in a Microsoft Word document and placed direct quotes from each participant under each theme (generate initial codes). I repeated this process until I no longer recognized connecting themes (search for themes). Each participant transcript produced between 13 and 20 themes. I then reviewed all of the themes and combined some into subthemes for four overarching themes (review themes). Next, I read the quotes from each participant under all four themes and their sub-themes to define them (define themes). Finally, I wrote notes about my themes and returned to relevant literature which supported my theme definitions (write up). I found this coding process effective and efficient because my participants shared very similar yet different experiences that echoed across the pages of the transcripts. 
It was as if the participants were not only sharing their stories with me but with each other.

My participants' stories were also the key to understanding their single experiences in their professional work environments and how those experiences affect them and their daily tasks on their jobs. Participants determine "what is told and how it is told, a process that can also depend on who is asking the questions" (Glesne, 2011, p. 186). My participants were comfortable sharing their narratives with me during the interview process.

\section{Trustworthiness/Validity}

Glesne (1999) outlined eight ways to ensure trustworthiness as a researcher: prolonged engagement and persistent observation; triangulation; peer review and debriefing; negative case analysis; clarification of researcher bias; member checking; rich, thick description; and external audit. Member checking, clarification of research bias, and, external audit were the three methods of trustworthiness I used in my study.

Member checking is key when conducting a narrative study. Member checking involved being transparent with my research participants as I shared my notes and transcription with my research participants. This method ensured that I told my participants' stories accurately. The women had the opportunity to clarify anything that I may have misinterpreted from their interview to guarantee their voices were represented in the study. It also allowed the women to add more information they may have forgotten to mention that could help strengthen their story. They also had the option to remove anything they felt did not represent their authentic truths. Only one participant sent back additional edits to her transcript. Also, I reached out to two other participants for more clarification about two of their responses after the interviews concluded because during the analysis phase, I noticed that I had a difficult time interpreting their words.

I recognize that I am extremely invested in the topic of Black women in diversity roles in 
predominantly White spaces in higher education because of my experiences of discrimination and isolation in that role. Thus, I had to own my research bias, but I remembered that not all women would feel the same way I did. Their stories, however, were similar in ways to mine, but in the end, they were unique to my participants. It was my hope that because I was aware of my biases, I would develop an accurate account of my participants' stories.

\section{Ethical Issues}

To address ethics in my study, I secured approval from the Institutional Review Board (IRB). During this process, I informed the board of my research questions, my reason for conducting the study, who my participants were, and how I maintained their confidentiality. Any information shared with me, I kept on my personal computer on my hard drive and Illinois State University's secure Microsoft Platform. My computer and Microsoft Platform were all password protected. I informed the IRB of how I planned to recruit my participants via BLKSAP.

BLKSAP is a private Facebook group, but it was still important that no one's identity was revealed when I recruited participants. I ensured that my positionality and interest in understanding Black women in college and university diversity roles did not interfere with the data collection and analysis.

I conducted this study for Black women in diversity roles who wanted their voices heard and who strived to change institutional cultures that were not designed for them. The women in my study shared information with me that they may not have shared with anyone before. It was my responsibility to protect that information. The first step I took in this process was to change the names of my research participants. Each participant selected her own pseudonym for the study. Lastly, my participants had access to every stage of my writing process. It was important that I shared what I wrote about them to ensure that it was accurate and truthful. 


\section{Conclusion}

The study results offered higher education practitioners important insights into the experiences of Black women in diversity roles. Charged with administering diversity education to our campuses, and educating students (and often faculty and staff) about inclusion and how to support differences, Black women often do not receive support in their predominantly White office spaces as they face forms of discrimination.

Black Feminist Thought posits that systems of dominance and power historically silence Black women's voices in society. Throughout history, however, powerful Black women used their voices as a form of activism and self-care when they faced adversity. My study filled the gap in the literature regarding Black women's experiences in diversity roles in higher education.

It is my hope that this study provides encouragement to other Black women in diversity roles in higher education. I presented a "road map" in chapter three which guided the remainder of the study. Black feminist thought (BFT) started the journey as I analyzed the data from my participants. I used BFT to identify if and how my participants' predominantly White office

environments perpetuated systems of power and how that power affected Black women working in diversity roles.

A cultural narrative study served as a storytelling technique that gave each woman an individual perspective regarding their experiences. The way to clearly understand a system is to highlight the stories of those who are marginalized. I crafted these stories from the one-on-one interviews with the participants via the Zoom virtual platform. 


\section{CHAPTER IV: FINDINGS - GIRL, LET ME TELL YOU \\ Introduction}

The purpose of this study was to explore the experiences of Black women who work in diversity-related positions at predominantly White institutions (PWI). For the purpose of this study, diversity positions were defined as roles held in housing and residence life as well as in multicultural affairs departments and centers. Using a qualitative research approach and narrative inquiry design, I sought to understand how the experiences of Black women in diversity positions affect their ability to perform the daily responsibilities of their positions. I used Black Feminist Thought as the lens through which to analyze the data. I conducted one-on-one virtual interviews with 11 participants to document their individual and collective voices (Collins, 2000) using their personal experiences as diversity workers, which are highlighted in this chapter. My conceptualization of diversity workers stems from Ahmed (2012). She posited that diversity workers' main responsibility is to institutionalize diversity, meaning their roles are "to redress existing goals or priorities" (Ahmed, 2012, p. 22). Each of my participants' job responsibilities helped redress their university's and department's goals for diversity and inclusion education.

To protect the identities of the participants, each of them chose their own pseudonym for mention in the study. I changed their job titles and did not include the names of their institutions. Table 1 provides a brief overview of the regional location in which they work(ed) and the number of years spent in their roles. All participants work(ed) in their roles between one to eight years, and many of them work(ed) at large, predominantly White research universities in multicultural affairs departments and centers in the Midwest, on the Westcoast, and in the southern part of the United States. This table is presented before section 1, which encompasses the individual narratives. 
The first section of this chapter "Who is She?" begins with the stories of each participant. In this section, I summarize their backgrounds, their transitions into diversity-related work, and lastly, their job responsibilities. The second section includes a presentation of the themes found in the data analysis process.

Four themes emerged from my research: 1) Black woman in diversity, 2) nail in a tire, 3) "standing in a crooked room" (Harris-Perry, 2011), and 4) just tryna' make it. The Black woman in diversity theme posited that each participant had their perception of what it was like to be a Black woman who works in a diversity-related position. I coded the term in vivo from Monica Shakespeare, one of my participants, as she articulated how she felt before accepting her current position.

The title of the second theme, nail in a tire is a metaphor to represent the various relationships my participants had with either White colleagues and supervisors, and Black colleagues and supervisors. Each participant either discussed the positive relationships that they had with colleagues (the nail in the tread) or they talked, in great detail, about how their relationships were severed with various individuals because of harm or distrust (nail in the side of the tire).

The third theme, standing in a crooked room, derives from Melissa Harris-Perry's book, "Sister Citizen". According to Harris-Perry (2011), Black women have "bent" themselves to try to fit into the "distorted images" the world has created about them (p. 29). The Black women in my study described several ways they had to metaphorically "bend" to try and "fit" into their work environments. They also described their colleagues' and supervisors' perceptions of them.

Finally, the theme titled just tryna' make it emerged from the descriptions of how my participants coped with what they experienced on a day-to-day basis at work. Several of them 
used therapy as a resource and some discussed their faith in God.

Table 1

Demographics

\begin{tabular}{ccccc}
\hline Participant name & $\begin{array}{c}\text { Institution } \\
\text { type }\end{array}$ & Location & Functional area & $\begin{array}{c}\text { Years in } \\
\text { position }\end{array}$ \\
\hline Sasha & Small & Midwest & Multicultural Affairs & 1 \\
Nubia Jones & Large & East Coast & Multicultural Center & 2 \\
Jade Robinson & Large & West Coast & Multicultural Center & 3 \\
Denise Watson & Large & Southeast & Multicultural Affairs & 1 year and 7 \\
& & & & months \\
Sharice Jones & Large & Southeast & Housing/Residence Life & 4 \\
Dr. Camille Reynolds (Dr. C.) & Mid-Sized & West Coast & Multicultural Center & 5 \\
Jurnea Williams & Large & Midwest & Housing/Residence Life & 2 \\
Monica Shakespeare & Small & South & Multicultural Affairs & 2 \\
Bailey Merrit & Small & Midwest & Multicultural Affairs & 3 \\
Skylar Rae & Small & Midwest & Multicultural Affairs & 1 \\
Zion Johnson & Large & Midwest & Multicultural Center & 1 \\
\hline
\end{tabular}

\section{Section One Participant Narratives: Who is She?}

\section{Monica Shakespeare}

I'm super religious in the fact that like whatever I'm doing I'm doing for God, so it's kind of like He's the one who's looking out for me so as long as I'm doing what I'm supposed to do, I'm good. I don't have to worry (Monica Shakespeare).

Monica Shakespeare is the Assistant Director of Equity and Inclusion at a 4-year, small to a mid-sized public institution in the southeast. Her position is in Multicultural Affairs. This is her second year in this role, but she attended graduate school and began her professional career in another department at the institution.

Born and raised in the south, Monica lived in an all-Black neighborhood until she was five years old. Her family then moved to an all-White neighborhood. She had a group of White friends as a young girl but soon connected with other Black children and made friends.

Matriculating through school was easy as she had a solid group of Black and White friends who 
considered her "elite" or "bougie". She said, "I was constantly considered bougie, though not stuck up, since I was nice. I knew that I had been raised to think highly of myself and to pursue excellence, but I didn't necessarily understand why 'it' was considered bougie.”

She described her childhood as somewhat "sheltered" from conversations about discrimination. She recalled that her family never talked to her about how to identify when she experienced discrimination and how to navigate those experiences. She thinks the reason her family sheltered her from those conversations was that many of them went to historically Black colleges and universities, were teachers in predominantly Black schools, and were raised in predominantly Black neighborhoods growing up.

Monica was one of 25 Black students who graduated from her predominantly White high school in her hometown. One year, she became the first Black woman to win "Miss Southern High School" (SHS). She recalled how happy she was when she won but did not realize until later why her being the first Black woman to win, was an issue. Monica said:

I always saw it as like the great accomplishment, but I don't think I ever saw really the depth in it, until, kind of, once I got to college and actually saw how there should have been someone else earlier, or you know there's some other stuff that could have been done or even something I could have been doing, within the system.

Monica's decision to attend college out of state stemmed from her parents' divorce. It was "too much pain to bear." When Monica joined a historically Black sorority, her line sister talked to Monica about discrimination when she heard people tell Monica that she "talked like a White girl" or use other microaggressive comments. Her line sister gave her the individualized conversation Monica missed out on growing up. Monica said,

When she would go home, she would take me with her to high school football games, 
would introduce me to her family and accept me, while still explaining to me that White people may talk to you and be your friend, but their intentions may not always be as real and genuine as I might think.

Pathway to diversity position. Monica's first position at her current university was in another department within the Student Affairs Division. After three years in the role, the Vice President (VP) asked her to serve as the Assistant Director of Equity and Inclusion of the newly formed Equity and Inclusion Office. She continued:

Um, I think one of the reasons that the VP asked me to apply for this role though was because she knew that I could be a good marketer for inclusion. Um, and so, that's the realm we focus on here we don't really go on, you know, social justice, or any of that. It's more inclusion. So, inclusive excellence that's her, you know, her goal here is not to talk about diversity and race and all that, which we, you know, we do but that's not the main focus. She wants it to be on inclusion and how everyone needs to get along and appreciate everyone's differences.

Monica suspected that one reason the VP wants the department to focus more on inclusion is to "keep the peace" on campus. Monica shared:

[To] not, you know do too much that could have people asking questions or bringing up "uproar." Or any of that just turn to keep it as a nice civilized you know, way of thinking. Um, it's been something to, you know, navigate to...I guess I try to have conversations with her just to kind of see like, "we going this far or we not this far?" just to kind of see what are the realms that we need to stick inside of, and so it's always best to just err on the side of caution when we put anything out or do anything, so.

Although Monica recognizes that being tapped for this role was a suitable opportunity, she also 
questions the motives of the VP when selecting her for the position. She explained this further:

But, I mean, you know, when you're asked to apply something you have to take that option and take that chance and if someone sees good in you, then you know you have to do it. But sometimes I do question I'm like, hmm, did she do this because I am more of a safe person and I'm going to make sure that we focus more on inclusion and not, you know, get, quote-unquote, 'too, too in the weeds of things' and you know, make people question too much? But, I mean, and we want them to question and ask questions, but I think it's just a whole different realm of life.

Job Responsibilities. As Assistant Director of Equity and Inclusion, Monica said she does not have many parameters in her job responsibilities. She supervises one professional staff member - Coordinator of Equity and Inclusion, supervises seven student staff members and three interns, and oversees the diversity programming in the office. She works with students, faculty, and staff to build diversity trainings for their various areas. Her office collaborates with other campus partners on large diversity initiatives and programs throughout the year. Finally, she oversees the multicultural competency certificate program. This program educates the campus on multicultural competence and they receive a certificate at the conclusion of the program.

\section{Dr. Camille Reynolds}

I want to be able to leave here, and not have myself or my name in anybody's mouth when I go, and to know that I've done my best and then whatever people have made up in their head about me and what I do, or what I don't do is on them and not me (Dr. Camille Reynolds).

At the time of the interview, Dr. Camille Reynolds (Dr. C.) was the Director of the Black Cultural Center at a mid-sized institution on the west coast and the only Black woman in the Student Affairs Division. She served in that role for five years. Dr. C has transitioned to another another university into a senior leadership role. 
Dr. C. described herself as an introvert and "a recovering perfectionist." She is originally from the west south-central region of the United States. She prides herself on being "a military kid" as her family moved around several times during her adolescence. Dr. C reflected on her experiences living around the world and how it prepared her for the work she was doing. She stated:

My family left [the U.S.] and we lived in three different countries. So, I've done a lot of international travel and a lot of who I am and how I show up in my work and how I how I strive to stay connected to others is connected to my, my experiences living and traveling abroad.

Her journey around the globe brought her back to the United States to pursue her college education. She recalled wanting to be an optometrist when she was younger, but when she started taking classes in college, she realized that career was not for her. A mentor of hers encouraged her to pursue a degree in English, instead. After completing her bachelor's degree, she went to graduate school to study adult higher education, a program she said she "fell into" because she does not recall how she enrolled in the program.

After she completed her master's degree, she worked for AmeriCorps for a few years. AmeriCorps, a non-profit organization, assists high school students in their matriculation to college. Dr. C. said that her first love is supporting students and showing care, and AmeriCorps was the place for her to do so.

Towards the end of her tenure at AmeriCorps, Dr. C applied for a doctoral program at a university in the northeast region of the United States. The higher education program denied her admission when she first applied. She said she does not know if the reason they denied her was because of racism; however, a faculty member in the department told her that her application 
"wasn't good enough." She took one class in the program to prove to them she qualified for the coursework and they "finally admitted" her.

Pathway to diversity position. Dr. C. did not complete her doctorate while she was living and attending school in the northeast. She said that the faculty members there were not committed to her finishing and that if she was going to get the degree, she had to commit to finishing on her own. She left and moved across the country to pursue her new role as Director. She did not complete her degree until she was already working as the Director of the Black Cultural Center, and because of the demands of the role, she struggled to complete it. She continued,

I had to like get it together and finish the degree, so, I defended in May of last year, May 2019. And it was really difficult to be working and writing, and trying to take care of everyone else, and smile and be good for everyone. And, you know, people ask how you are doing, lie and say you're doing okay. I-I still don't know how I made it. I was also diagnosed with a chronic illness like I don't know, I really don't know how. People must have been praying for me and I can't say I'm a praying woman anymore, but they must have been holding me up because there's, there's no reason I should have finished.

Dr. C. continued to reflect on what it was like navigating work-school life and how her colleagues treated her after she completed it. She shared,

Um, and I just realized how much it took out of me like trying to manage my education AND be a director AND, you know, try to make sure you know students aren't selfharming. Like it just was a lot. And I thought last year was a lot, but this year is even worse, and I thought it would be better, like right? People call me doctor and my life is supposed to open up and be grand and it is not. It is the opposite of that. People have 
issues calling me, doctor, I don't know if... [speaking directly to Tristen] I hope you don't have that experience. I really, I really, really hope you don't have that experience.

Dr.C's experience of not being called "doctor" could stem from her colleagues' perception of her when the selection committee chose her for the Director position. This position was Dr. C.'s first diversity-related role. She said that when the search committee selected her as the candidate, many people at the university were not happy. She said,

So, there was an internal candidate who I think thought they were a shoo-in.

And there was just a lot of frustration and controversy over me being selected. And it made things really difficult because I don't think there had been a real legitimate hiring process for a director in this role until I interviewed. (Dr. C. sighs). That meant I was coming into a lot of things that were not necessarily structured that students didn't have really high expectations for themselves and then I had a lot of pushback, and it was hard.

Job Responsibilities. Dr. C. described herself as a person who wore "many hats" in her role because she found it difficult to articulate all the responsibilities of her position when asked. She supervised 13 undergraduate and graduate students and oversaw the operations of the center but admits that she wished she could do more for her center. She shared,

And I've been on edge. So, I'm like I do everything, and I like that I don't even know how to, how to capture that for you because I don't get to do sort of the higher-level director focused workaround like strategic planning and like supervising other people to do some of the things I probably shouldn't be doing. So, I probably operate more as a what I imagine an assistant director or coordinator would be doing but doing everybody's job so being coordinator, being assistant director, with little resources and not enough time. 
She serves on nine university-wide committees and is an adjunct professor, which makes her time limited in the center. She said:

I think I'm on nine university-wide committees. And maybe that's why I'm trying to take myself off of those committees because they take up a lot of time, and the yield is not exactly what feels good to me in terms of the use of my time.

Dr. C. was being pulled in multiple directions in her position as Director and it had an effect on the relationships she had with students, which she explains later in this chapter.

\section{Sasha}

You know, there's times I have to go out and I have to have, you know, my, my gun on my hip and be ready to advocate for students (Sasha).

Sasha is the Coordinator of Student Outreach and Mentorship in the Multicultural Affairs department at a small-sized institution in the Midwest. She will soon start her second year in the role and prides herself on the relationships she builds with underrepresented students on campus. One of Sasha's future hopes is that she can remain in frontline institutional positions, similar to her current role (with more pay), because she does not want to lose connections to students.

Although Sasha enjoys serving and working with students, she is no stranger to having the desire to help others. Growing up in a predominantly White town in the Midwest, she aspired to become a doctor. She played sports and participated in other organizations in high school, but she said that "everyone knew she wanted to be a doctor." This burning passion pushed her into pre-med as an undergraduate student-athlete.

She was raised with a family of educators. Her father worked with the local TRIO Upward Bound Program, her mother taught English and Spanish, her sister is a principal, and her brother also worked in an area of education which was not mentioned. Thus, the desire to pursue medicine was a bit off course. It was not long after she started her undergraduate career that she 
contemplated adding education-related coursework to her schedule. Her academic advisor did not agree with the choice. Sasha explained:

At the time, my advisor, my early childhood advisor, I felt like... she didn't want me, she was kind of like "you can't do both,” which is, you can't tell me, you can't, like, I'm like, “oh okay, so, I am going to do both because you said I can't.” Because her, her disposition was more like that's impossible. You can't do it and I'm like, “no, it's possible"...Um, But it wasn't, I could- think I kind of felt, you know, the stories of your parents saying that one White teacher told them they couldn't be what they wanted to be. Because it wasn't feasible for a Black person to do, that's kind of what I felt from her. And not to say that she was racist but that's what I felt. I didn't feel it was coming from a warm place of, you know, "you need to rethink this, this is impossible it's never been done." It was kind of like, "Who are you to think that you can do this?"

Sasha's career ambitions of being a doctor ended after she suffered many injuries from playing sports. As she was in an out of doctor's offices, she noticed that the doctors were not personable. She knew that she wanted to connect with people in her future career, and becoming a doctor seemed less appealing.

Pathway to diversity position. Sasha completed both the pre-med degree and early childhood education degree in five years. While she was balancing two majors, her father connected her with the TRIO Upward Bound (UB) Program where she worked every summer. UB allowed her to work with underrepresented students.

As the excitement of graduation was still fresh on her mind, Sasha realized there was a law in her home state that required individuals with teaching degrees to teach in the state for five 
years to keep their degree. She stayed in her hometown to teach and work with UB over the summers. Staying involved with UB kept her connected to college students.

After ten years of teaching, Sasha was "fed up" and ready to move on to a new chapter. She resigned from her teaching position and set out on the job search for higher educationrelated jobs in a large metropolitan city in the Midwest. Soon, she applied for her current role as Coordinator of Student Outreach and Mentoring. One particular part of the position intrigued her the most, "The student mentoring piece is the piece that I wanted, working with students. And um I got the interview."

She said that during her interview, the search committee questioned her about how her work experience with UB and first-grade teaching made her qualified for the role. She said, I don't know but they never really consider Upward Bound, maybe they don't know about TRIO programs like I did. You know come from a family of it, but they never considered how much work [you] really have to do in Upward Bound position. And so, just to kind of help people understand the connection for me, it was an easy match. First grade and my position here are so similar because you have students at the brink of life. They don't know who they are. They can identify certain things about their lives, and they need someone with patience and understanding that can help them make the decisions of life because they're not really adults yet. And it's the same way with first grade. You have students who are just now learning. They are, you know, weird about the education process, they're figuring out their strengths, what they're not good at. They're at the observational stage where you're trying to identify them, what they need, services that will carry for the rest of their lives. And it's really the same, the same things, you know like if you look in the eyes of freshman year college student, they look the same as 
the eyes of the first year first-grader, because they're just starting, they don't really know they don't really understand.

Job Responsibilities. As Coordinator, Sasha is responsible for student outreach and mentorship. Student outreach is the nucleus of her position, which occupies approximately 75 percent of her job responsibilities, and 25 percent of her role involves student mentoring. However, she believes mentoring is the component which occupies most of her time. When speaking about her student outreach responsibilities, Sasha highlighted that the students at the center where she works connect to people. She said that her position was vacant for almost 18-months before she started and because of that, the attendance at one of the center's most popular programs declined. She had to work to rebuild relationships when she started. She said,

It's one of those things that when you lose contact with the person that's there, you lose the population of the students. And so, students were coming [to the program], but it had died down, so you know, fifteen is about expected and died down to like maybe two or three. Um, students didn't feel connected to... because um the workshops were still going but the person in the position was gone, so there was no student mentor for a while. Um, only a couple program advisors and then the assistant and the director and so um when I took the position over, we kind of had to go back to the social-emotional workshops, more than just the academic things on campus.

One of the social-emotional workshops she oversees involves a partnership with the counseling center on campus. This "power hour" program gives students space to express how they feel about various prompted topics without judgment. Sasha continued,

We have a topic and students can just come in and kind of unpack what they feel there's 
no um agenda, there's not necessarily a format, um they just sit chairs around, and we have a topic in whenever they want to talk about it however the conversation goes, we're just open to that.

The mentorship component is her favorite aspect of her job responsibilities. With this task, she ensures students have what they need and have access to her. She has chairs lined up in her office for students to sit when they wait to meet with her. She had to request the chairs because she used to have a line of students standing as they waited to see her. Sasha also recognizes that students often just need each other or need to know they have someone available. She explained,

Sometimes they just come in, they just want to say, "Hey Miss Sasha," they want to say, “Oh, I feel like dropping out today." They will say, "oh this test sucks.” And they just need that space. And so, about two or three weeks ago I was just like, you know what, I'm just going to add chairs, you know, so I just added extra chairs in. There are at least two or three times a week, every chair's full, and they're just having this impromptu life talk sessions. And I don't always have to be in the middle of it, you know sometimes students need to close the door and say, "this is what I'm going through, this is what I need." And sometimes they just need to identify with each other so the student mentor piece for me was just kind of being present, being available. But, you know, I think last week they kind of joke, they're like "you gotta start kicking students out." I'm not there yet. I know they need it too much, I can't. This is a part of the job, and I'd rather stay at nine or ten and do my thing than to take away from them.

Sasha understands how important it is to take time for students. This connects back to her love for mentorship that her position provides. 


\section{Jurnea Williams}

I love and appreciate very passionate social justice-oriented people, but if you're not fit to lead and manage, not just lead but also manage big budgets, people, etc. you don't need to be doing this work (Jurnea Williams).

Before she transitioned into her current role as the Assistant Director of Residence Life Diversity Education at a large research institution in the Midwest, Jurnea Williams was the Program Organizer in Residence Life - Diversity Education for six years in the same department. The Diversity Education department in Residence Life integrates diversity and inclusion into the Residence Life department. They work collaboratively with hall staff and administration to facilitate trainings and workshops for the undergraduate and graduate students who live in the residence halls.

Jurnea grew up in the south suburbs of a large city. She attended public schools during her formative years but transitioned to a private school for high school. Her private education continued into her undergraduate career at a Catholic institution where she studied social work and dived heavily into student involvement activities. Jurnea described her undergraduate institution as "affluent" and, because of the privileged institutional culture, it was important for her to make connections across differences. She remembered being the first Black student body president at the university and often the only Black person in other organizations such as the softball team. Albeit having an "only one experience" at the university, she built community with other students of color, LGBTQ+ students, and other underrepresented students.

She continued immersing herself in diverse experiences in graduate school at a Big Ten university. Jurnea studied social work in her graduate program with a focus on management but worked in the Study Abroad Office. It was here where she "fell in love" with intergroup dialogue as she had to coach students regarding how to navigate various cultural identities. She said, 
I fell in love with intergroup dialogue in the dialogic process in general and the ways in which that helps to um facilitate uh self-awareness, but then also perspective-taking to understand other cultures and identity and life experiences and realize that the work I desire to do could happen in a collegiate atmosphere.

Pathway to diversity position. Jurnea's experience as an undergraduate and her time spent working in the Study Abroad Office in graduate school were the two instances which began her journey into diversity "work." Surprisingly, her first full-time professional position after graduate school was a hall director (HD) and not a diversity-related role. For two years, she worked in residence life as an HD at the same Big Ten institution from which she earned her master's degree.

Her combined experience as a hall director and with intergroup dialogue made her the perfect candidate for the Program Organizer (PO) job at her current institution. Housed in the Residence Life Department, Diversity Education provided Jurnea the opportunity and support to create and develop fresh experiences for the department. She said,

As a program organizer, I had free rein to do almost anything I wanted. There were very few times that I was shut down or like met with a major obstacle and just told "no." Jurnea was not only encouraged when pursuing her creative initiatives, her professional development was financially supported as well. She said,

I mean, there have been years where I've gone to like five or six separate um conferences or professional development opportunities um literally to fill my tool kit to be able to bring it back to the institution as it relates to like diversity inclusion um conferences and experiences. 
The confidence in her by her department constituents was evidenced by her promotion six years later to her current position as Assistant Director of Diversity Education. Jurnea's job responsibilities changed from frontline programming to senior management decision-making.

Job responsibilities. The Residence Life Department at Jurnea's institution classifies Assistant Directors as members of the senior leadership team. The residence hall staff (hall directors) is racially diverse, however, Jurnea is the only Black person represented in senior leadership. Because of this, Jurnea holds a unique, unspoken job responsibility, which includes advocating for other staff of color to senior leadership team members. This is discussed later in the theme section of this chapter.

As Assistant Director, Jurnea supervises three full-time program organizers, oversees office operations, is one of the main diversity and inclusion trainers for the department, chairs several committees dedicated to diversity and inclusion, and indirectly supervises the student peer education team. As a diversity and inclusion trainer, Jurnea trains groups of people to help them understand changing policies and demographics. She recalled a time when she had to train the facilities staff. She shared,

I think of a time where we had a [member of our custodial staff] who almost was like policing the bathrooms where they saw someone who visually appeared to be one gender and was going into a different gender restroom. So, then I had to go talk to facilities about what it means to be gender-inclusive, not just in like using pronouns, but like our actual practice and how we engage our residents and really for them as our customers... While training is an area that she has full creative authority over, sometimes Jurnea faces obstacles when chairing and participating in diversity committees. She continued, A colleague asking me to chair or to lead campus-level diversity committees and such 
like um and actually putting sometimes financial and other types of resources toward it, but I've also experienced where it feels like it's just leg work. And it's typical like "a'ight, produce this report to present to the executive team," and nothing happens with it and that is very frustrating. Right? And so, I've gotten to the point of starting to say I'm not going to serve on certain committees because until y'all really ready to do something. I don't want any parts of it. So, that has been challenging in that's been both internal and external.

While Jurnea often feels frustrated with diversity committees and their goals, her desire to continue in her role as a diversity worker has not been deterred.

\section{Bailey Merrit}

I didn't really understand my own Blackness. I knew that my mother ran from White kids when they were walking home from school back in her days. I knew that my father didn't have a good upbringing and he didn't even graduate from high school, but I didn't understand my Blackness. I didn't understand my Blackness until... as a [member of my community] and the [other] folks in my community, we stood up to the murder of Michael Brown (Bailey Merrit).

For three years, Bailey served as the Director of Diversity Programs in Multicultural Affairs department at a small-sized university in the Midwest. At the time of her interview, she worked as the Assistant Director for Diversity Opportunities in the Castle School of Business, an academic department, at a large research institution in the South. She recently resigned from her role as Assistant Director.

Bailey was born and raised in a large metropolitan city in the Midwest. She is moving back to her hometown upon her resignation from her current position. She grew up in a singleparent household with her mother and spent weekends with her father. Bailey and her mother were and still are very close.

She described graduating from high school as "challenging" because she was on the brink 
of failing an algebra class. Her algebra teacher refused to allow her to fail. Her teacher called Bailey's mother to encourage her to pass the final exam. Bailey assured her mother she would pass, and she did. Her high school coursework was not challenging enough for her, so she did not put in the effort to do the work. She wanted more.

Bailey planned to take full advantage of her education when she made her choice to attend Tennessee State University, a historically Black university (HBCU) for college. She changed her college path when her mother asked if she could stay closer to home and attend a community college. Her mother needed help paying the bills as her mother and Bailey's father were separated. Bailey obliged and enrolled in a community college close to home but stayed in contact with a friend who attended Alabama A \& M University (AAMU), another HBCU. Her friend encouraged her to apply to AAMU so Bailey could transfer to the university after community college, but when it was time to transfer, Bailey could not pay for the tuition. She attended a small private university in her hometown, instead, to complete her bachelor's degree.

As a first-generation college student, Bailey worked a full-time job and had an 18 credithour course load. She found community on campus when she met a Black woman full-time professional who encouraged her to get involved in the Black community on campus. The woman became her mentor and assisted her in her transition to graduate school at another institution in the area.

Pathway to diversity position. Although Bailey attended a different institution for graduate school, her first and second assistantships were at her undergraduate university. She began her first assistantship in the Admissions Office in August of 2014, which was approximately during the time of Michael Brown's murder. She struggled between advocating for her Blackness and protesting in her community about Mike Brown's death and recruiting 
more Black students to the university. She said,

So, I'm out there with my friends, protesting in [the community], going to school, trying to recruit students to go to [this university], under this mission of, "we want you here, we want you to excel" which is still not true. And I'm battling with all of that. So, in the sense of battling with my identity, understanding my Blackness, reporting to a White woman at the time, I was just like, "I can't do this. I need to do something more. If I'm gonna do this work I need to do it with purpose, and I need to do it with intentionality." Bailey advocated to switch assistantships and work in the Multicultural Affairs Office with the Black woman mentor she had as an undergraduate student. This assistantship was the catalyst for her continued work in diversity. In this role, she and her mentor created spaces for students to process Mike Brown's murder which included a task force to address these issues at the university and Bailey created an event series to invite speakers to discuss social justice issues. Reflecting on all of the work she did in her assistantship and in the community, she shared how she felt when the world heard the verdict from the trial of the officer who killed Mike Brown. She said,

I'll never forget the night of the non-indictment and being in my graduate room and watching them say that Michael Brown's murderer was not going to jail. So, that was just a lot of - that was just a very emotional time. That was a time when I really came to grips with my Blackness and that as a Black woman, I walk this world and the way that I navigate this world is totally different from anybody else. It's even different from a Black identifying man.

After graduating from her master's program, Bailey accepted a full-time position as the Director of Diversity Programs at a small-sized institution in another state. She served as the 
Director for three years before shifting into her role as Assistant Director for Diversity Opportunities in the Castle School of Business, across the country. Both positions served her differently, but they each had similar job responsibilities.

Job responsibilities. Bailey had many tasks in her first position as Director of Diversity Programs. Multicultural programming, multicultural retention initiatives, and multicultural student organizations were all essential initiatives under her purview. Her office also partnered with campus departments such as housing and residential life to create learning communities dedicated to identity in the floor communities of the residence halls.

As the Assistant Director for Diversity Opportunities in the Castle School of Business, programming was not a high priority in this academic department. Instead, Bailey’s responsibilities focused more on building community within the underrepresented student population in the Castle School of Business. This was something Bailey made one of her priorities in her position, as this was not part of her job description. She said,

One thing about my role is, all the time, we're helping all students, but I always make sure that I am paying close attention to um the progression and the mental health of my students from underrepresented backgrounds. So, through doing that, I work with our affinity groups: our Black student network group, our Latino network student network group and our women's business group.

In addition to supporting the underrepresented students in the School, she assisted the Associate Dean of the School of Business with workshops and presentations regarding a diversity and inclusion framework, which is an assessment instrument that demonstrated that universities are "hitting their mark with diversity and inclusion." Throughout the rest of the year, they planned small-scale events to bring awareness to differences within the School. 


\section{Skylar Rae}

I think the hardest thing about being at this predominantly White institution is getting people to understand um their microaggressions, their language, their actions and behaviors, and knowing that it's not okay (Skylar Rae).

Skylar Rae serves as the Coordinator for Multicultural Events in the Multicultural Center at a small-sized stem-based institution in the Midwest. Skylar was the first person interviewed after the country-mandated shut down because of the COVID-19 pandemic. She was late to the interview because her university announced their shutdown while a group of her students were on their way back from an alternative spring break trip sponsored by her office. Skylar had to determine how to inform students regarding the mandatory 14-day quarantine which would begin upon their arrival back to the university.

Skylar is from a culturally diverse city in the southeast United States. Her mother was an aide in a retirement facility while her father drove taxis. She grew up in a low-income community but did not know that her family was "poor" until she started college. She said, "My parents didn't have money, but I never lacked anything. Shout out to them.”

She went to a predominantly Black elementary and middle school and recalls the students teasing her because she "talked White." Her high school was more diverse, but she spent most of her time focused on her academics, as she remained on the honor roll. No one in her household discussed the importance of education or college, so she motivated herself to focus on her academics and apply to college. She was a first-generation college student and she knew she "had to do it [go to college] because her parents didn't get a chance to."

One of her strengths is her ability and willingness to help others. She said her peers and adults would often seek advice from her growing up, given they trusted her opinions. She used this strength as her fuel to study psychology in college. Helping people was a skill that she 
desired to continue into as a career. While she studied psychology, she was an active student leader in multiple organizations. She joined clubs such as the step team and the Black Student Association. She found a home in the TRIO office and became a mentor to other students to guide them through their college experience.

Unfortunately, after she graduated from undergrad with her bachelor's degree in psychology, she struggled to find employment in her field. Skylar quickly shifted her focus to graduate school. She stayed at her undergraduate institution for graduate school and studied mental health counseling. Her assistantship was in the Multicultural Affairs Office, but she also held an outside job in the substance abuse unit at a group home for teenage girls. She worked the dual positions for a brief time, and she resigned from her post at the group home and continued to work in Multicultural Affairs.

Pathway to diversity position. Skylar's graduate assistantship in Multicultural Affairs was the entry point for her career as a diversity worker. When she graduated, she left Multicultural Affairs to pursue a doctoral degree in higher education. She served as a research assistant for the K-12 program but desired to return to diversity work. As she reached the end of her course work in her doctoral program, she applied for Multicultural Affairs positions and pushed herself to apply for positions outside of her home state. She said,

I woke up one day and spirit told me, you know, look like, "why are you only looking [at home] for a job?" And so, because I have no obligations at home, um, and like, it's only me, I'm responsible for me.

During her on-campus interview for this role, Skylar was unsure if she would take the position because she was a candidate in another process at another institution. After she met with some student leaders on campus, she realized that campus was the best fit for her. 
She said,

I asked students like, "why are you at this university? What makes this university so important and unique?” And they told me the Multicultural Center...It's a home away from home. And that's their words exactly.

Skylar soon left the warm weather and sun and traveled to the cold weather and four seasons. Skylar discussed,

This guy coined my journey. He said, "I no longer consider you crazy, [for moving away] but brave"...And so, um born and raised [in the south] never been in the snowy culture, never had that background and understanding. And then I moved [up here] where it snows six months out of the year.

Job responsibilities. Skylar is fairly new in her position. She recently celebrated her first work anniversary around the time of the interview. Her role as Coordinator has many responsibilities. She works closely with the summer residential internship program, co-teaches a research course, and is responsible for the heritage month programming (e.g. Black Heritage Month, Hispanic Heritage Month, LGBTQ+ History month, etc.).

One of the first duties she had as Coordinator was to lead the diversity lecture series. This series objective included brought speakers to campus to lecture about various topics related to diversity and inclusion. The series allowed people from "all walks of life" to come together to have conversations about differences. She said,

People come on campus talking about different issues um, just having healthy discourse and getting people to think um about just not our little area in [our state], but just around the world, what's happening. And so, um those speakers come from all walks of life. And so, actually my second day of work, I met um Ilyasah Shabazz, which is the 
daughter of Malcolm X. So, that was pretty cool.

Her favorite aspect of her job, though, is the peer-to-peer mentoring program that connects first-year students with upper class students to create a "sense of belonging." The upper class students assist them in their transition from high school to college. Skylar said, "that's part of my job that I love the most is having that connection and seeing that growth and seeing those relationships build."

\section{Jade Robinson}

When I got into the racialized space as an affinity space solely supporting a certain demographic of students and was meant to be in coalition with other people, it was like anti-Blackness and hate was at the forefront of our colleagueship or friendship (Jade Robinson).

Jade Robinson serves as the Assistant Director of the African American Cultural Center at a large-sized institution on the west coast. This is her third year in the position and her first job in a cultural affinity space. It is also her first professional job after earning her master's degree.

The west coast is Jade's home. She grew up in a predominantly Black city in a singleparent household raised by her maternal grandmother. She remembers the tight-knit Black community around her. Everyone knew each other and everyone knew her grandmother because she worked at the local park in the neighborhood. Her grandmother was the "auntie," "grandma," and "mama" of the community, and Jade recognized that her grandmother was not just "hers."

Jade loved her community. She described it as an "unhealthy, stable-ass, healthy space" because there were people in the community who struggled with substance abuse and there were socioeconomic disparities. However, the relationships she built with her "extended family" meant the world to her.

Her community members thought she was special. They often told her that she was "going somewhere" because of how active she was in the city and in her high school. She had 
familial ties to her high school given her grandmother attended the same school, as did her grandmother's mother. When it was time to apply to college, Jade was eager to go as she was a first-generation college student.

Jade's biological mother resisted filling out the FAFSA form. Her mother did not want to cosign on a student loan for her to attend college. Jade continued,

My mom was like, “Oh, I don't want to cosign on a loan for you to college.” And I was like, "What?... I'm from the hood, I'm going to college. I don't care what's gonna happen.” And I was first-gen and so it was interesting to see that like, my mom was very adamant about like "you need to be this type of person and go to school and not fuck up your grandma life.” It was also interesting that like you [her mother] would have held me back because you -you have fears, financial fears.

Jade described her undergraduate experience as "lit" because her institution was approximately 60 percent Black. She found community with the Black students on campus and was active in the Black Student Union and joined a historically Black sorority. When she joined the orientation team (O Team), Jade made it her duty to recruit more Black students to join the $\mathrm{O}$ Team to diversify the group.

She graduated with her degree in child development. She did not pursue a master's degree right away. Jade worked a few jobs in infant development and at a well-known multimedia company back in her hometown when, unexpectedly, one of her old bosses from college reached out to her on LinkedIn and asked her if she wanted a temporary full-time job working in orientation. She accepted and went back to work at her Alma Mater.

When her contract was up with orientation, she transitioned into the National PanHellenic Council (NPHC) advisor role in fraternity and sorority life. She stayed in that role for 
two years before leaving the institution to begin another Greek life position at a prestigious predominantly White university in the state. It was in this role where she realized she needed to pursue a master's degree because her colleagues were working on assessment plans for their offices and Jade felt like an "imposter" because she did not know what assessment plans were nor did she have experience with them.

Pathway to diversity position. All of Jade's previous experiences working in the Student Affairs Division as an undergraduate, working with Black students, and post bachelor's degree professional positions, made her an ideal candidate for her current role as Assistant Director. She did, however, notice a few red flags when she interviewed for the job. She explained,

My whole open, like on-campus interview, I felt triggered in different capacities. But when I think back to it was muddled also with this conversation of like, "you are coming from this other state that's really um like, diverse and like, you know, got a lot going on. Why would you come? We can't retain you."

Jade believes that some of the committee's skepticism about not retaining derived from their preconceived notion about who she was. She continued,

Some of that might have been like, "oh, she's coming from [another state]. She's a young Black professional. She's female. Like, what can we can't really do shit with her here." This podunk ass town like has nothing to offer me, right? And so, I think I also learned later that I was my director's first female hire. So, I don't know if that played anything to like her kind of own projections or assumptions about what I would need, you know, what didn't exist, what she had to build probably over time. So, I think it was probably was like a "you're coming from [a prestigious university], why would you come 
here?"

Another red flag for her during the interview was when the committee discovered she was a member of a historically Black sorority. They asked her to not "show up in that capacity" because there was unexplained "past harm" in the campus community with NPHC identifying professionals. She believed the committee thought members of the campus community showed favoritism towards NPHC members. Nonetheless, Jade accepted the position.

Job Responsibilities. Jade described her job responsibilities as "too much." She hires, trains, and supervises a coordinator and all the student staff members in the office. She has complete oversight of the office's budget and cross-campus collaborations such as studentathlete mentoring. Her office assists with first-year student retention efforts, so they create events and programs to support students in their transition to college.

Interestingly, soon after Jade started, the university brought NPHC Greek organizations back on campus and she was the first person they asked to advise them. She mentioned, That opened an opportunity for Office of Fraternity and Sorority Life and our office to have a partnership which now I serve as a staff member within OFSL to some part-time capacity or half time capacity. So, really just as an advisor to NPHC initiatives and supporting um that community, but that wasn't necessarily a part of my role. But it was what I was adopted into as that community grew.

As aforementioned, the search committees explicitly explained to Jade to not show up in a "Greek capacity" during her interview but the campus soon recognized that they now needed the support. Jade gladly accepted the role and additional compensation. She said,

The directors of those spaces had a conversation that I was invited into considering whether or not that's something that I'd be interested in or willing to do. And then we 
talked about what like compensation will look like or um commitment. Uh, we did that intentionally but also loosely, right? Like, I don't think we anticipated even in that one time conversation, what the road would really look like ongoingly, how the community would change, needs to change, um and any potential harm that would arise or risks.

\section{Nubia Jones}

I've never felt that really aggressive um, need to declare my Blackness because it's always just been it's been established very much like Black's great, it's great being Black, it's lovely to be Black, like, with music, with art, with history with science and all those things like that was fed to me.

Nubia Jones is the Assistant Director of the Office of Social Justice at a large-sized institution on the east coast. Her university is predominately White but also has official status as a Hispanic Serving Institution. What's unique about Nubia's position is that she oversees the LGBTQ+ center and the Women's Center while her former supervisor oversaw the multicultural center and the interfaith center on campus. All four centers encompass the Office of Social Justice.

Nubia was raised with a family who was proud to be Black. They taught her how to take pride in her Blackness and in who she was as a Black woman. Her father intentionally named her Nubia because of his love for Black art. Her parents were activists in their hometown on the east coast, and Nubia remembered being outside protesting drug addiction in the city with her parents when she was younger.

Blackness was not just in her household, her hometown was also predominantly Black, and she went to a predominantly Black high school. She grew up seeing herself reflected in all areas of her life until high school. Because she had a positive understanding that "Black is beautiful" she said that it was "very easy to internalize that." She went to a small performing art high school that was racially diverse. Nubia remembers small covert instances of racism at her 
high school, but also the select overt instances of racism which Black students experienced.

None of these covert and overt instances of racism detoured Nubia from loving her Blackness.

She admitted that although she loves her Blackness; she struggled with understanding the rest of her identities. She said,

I think my issue with my Blackness was more so trying to make the other parts of me make sense. Um because I do identify as queer and I just figured that out like maybe two years ago. And not that it wasn't encouraged in my home, but more so in the Black community um it can be discouraged or looked down upon. And I grew up in the Black church. So, that can also be like a not okay place to discover that or explore that. Um, But, I also felt the need to, I wanted so bad, to be that straight ally who is straight, like I love I care about these issues and I'm straight, it doesn't matter. But one day I was like, "Girl stop lying...you're not straight."

Her sexual orientation was not the only intersecting identity she held with her Blackness. She said that she is a lover of things that many Black folks would consider "not Black." She enjoys cartoons, video games, and reptiles. She holds all of her identities close to her because she believes that everything about her is part of her Black identity.

Pathway to diversity position. Although Nubia attributes her pro-Black background and activism in social justice at a young age as her entry point into diversity "work", Nubia began her professional diversity "work" as an undergraduate student in the same center she now oversees, the LGBTQ+ center. She attended undergrad and graduate school at her current institution. She volunteered in the office for the duration of her time as an undergraduate student.

During her master's program, she was the graduate assistant for that same office. Her mentor in the office taught her about intersectionality and what that meant for her life and other's 
lives. She stated,

He [her mentor] was definitely one of the people who um pushed intentionally and unknowingly as well, for me to go after what I wanted, like opening my mind in things like learning about intersectionality and putting a word to it, because we know this stuff exists, but we don't have words for it, we're not getting words for it, and we don't know the words for it. But teaching me about intersectionality and how our issues are queer issues, like homelessness issues are queer issues, racist issues are queer issues. And so that really invigorated me even more. But yeah, so I knew that I wanted to work, do diversity work in higher ed.

She remained encouraged into her first full-time job in higher education as a coordinator of a Women's Center at another institution. She worked in the role for approximately two years. After year two, she saw the opening for her current position and applied.

Job Responsibilities. Of the four graduate students in the office, Nubia supervises two of them, one for the Women's Center and one for the LBGTQ+ Center. She also oversees student volunteers and health intern volunteers who need a certain number of volunteer hours to meet requirements for their respective programs. Many of them volunteer with the center.

She is responsible for office programming which hosts various themed weeks, such as diversity week and Women's History Month. She collaborates with other offices to help plan Black History Month and Asian Pacific Islander History Month. She said that the full planning of the history months belongs to those specific affinity group caucuses on campus, so her office cannot fully execute them.

Nubia also oversees several other campus activities. For example, she facilitates an LGBTQ advisory board, co-advises Stonewall Suites Living Learning Community within the 
residence halls - a community for students who identify as LGBTQ+, and the social justice conference. They canceled the 2020 conference because of COVID-19.

As the LGBTQ+ advocate on campus, many students who identify within that community will seek out Nubia for support on campus. Individuals, often professors, will ask her to consult them on bias incidents directed towards the LGBTQ+ community. She said professors seek her out if they have a transgender student in their classes and want to know how to approach issues that may arise because of it.

\section{Denise Watson}

I really am in like a much better position now. And you know, I feel like I left that job [Multicultural Affairs] feeling like a little bit of um like a battered puppy...it's that feeling of like being in such an unhealthy work environment. And then you're like, in a slightly better situation. It's like, "Oh my God, is this what life is like?” (Denise Watson)

Denise Watson served as the Coordinator of Cultural Programming in the Multicultural Affairs Office at a large research university in the southeast. After one year and seven months of working in the position, Denise resigned from the role. She now works in academic affairs at the same university.

Denise and her parents immigrated to the southeast United States from Jamaica when she was five years old. Very early on, her young parents made an effort to provide her the "best education" possible. Denise said her K-12 schools were in "very nice neighborhoods." She continued, "And so, what we now know about, like, the history of redlining. We know that nice neighborhoods and schools in them mean predominantly White."

At an early age, she noticed that she was not like the other students in her classes. She said that she still had her Jamaican accent and spoke Patois and the children in her class pestered her about it. As a result, her parents enrolled her in speech therapy classes to help her “assimilate". Her accent soon diminished. Today, her Jamaican accent is unrecognizable. She 
said that she wishes her parents never did it. She continued,

Instead of like, you know, the solution to like kids making fun of my accent. It should have been like the education for the rest of the classroom. Not for me, right? Um, and I also feel like it's this aspect of, you know, immigrant culture where you come to America and you have to assimilate...thinking about my parents and the generational differences, right? It's like they were just trying to do the best for their, like little Black girl that they could, you know, in a world where they're seeing, you know, in Jamaica, everyone's Black and brown. Also, them coming to America was like, the first time where they're experiencing racism.

After she graduated high school, Denise attended an in-state university five hours away from where she grew up. During her undergraduate experience, she noticed the differences between "being Black and international and being Black and domestic American." Experiences such as Black Greek Lettered Organizations were unfamiliar concepts to her. She says that because she was Jamaican and attended predominantly White schools growing up, she did not learn about this aspect of Black culture. Instead, she learned more and created an individualized experience with people who were culturally different from herself.

Pathway to diversity position. During her undergraduate career, she studied hospitality management and worked at a hotel in a "podunk" town (a small, rural town that is uninteresting) in a rural area of the state. The people she met there had limited experiences with people from differing cultural backgrounds. Denise said many of them never met people who had religious beliefs outside of Christianity. They resisted any education about differences. Denise said, There was a lot of that like, um mentality of like, "I fear this" slash "I'm gonna insult it because I have not seen it" slash "I have no experience with it." So, a lot of like the 
xenophobia, homophobia, racism, like all the things that because I feel like this

population of folks didn't encounter differences a lot were so resistant to it.

This experience, coupled with her undergraduate experience of recognizing differences, made Denise want to go graduate school and work in a "diversity capacity."

Denise enrolled in the Student Affairs master's degree program at her current institution and applied for the graduate assistantship position in the Multicultural Affairs Office. She credits the Multicultural Affairs position with helping her form some languages she uses today. She discussed what she looked for when she applied for the assistantship. She said,

What office that could teach me the language that I've always wanted to know or be able to engage with and all these different experiences that I have. It really did teach me a lot of the language that I use today, right? And it allowed me a space where during work hours I could look more into like topics of like, like I mentioned redlining and just the historical context of racism and partiality within the United States.

She worked as a graduate assistant for the duration of her graduate program and accepted the full-time Coordinator position in the same office.

Job Responsibilities. As Coordinator, Denise had creative oversight of the cultural programs on campus. She created celebrations for months such as Black Heritage Month, Hispanic Heritage Month, and Asian Pacific Islander Months. When she programmed for these specific months, students with those cultural backgrounds felt more comfortable interacting with her. She mentioned,

Okay, so Asian American Pacific Islander Heritage Month, right? I think that was a good example of like, the duties of my job led me to learn about things like Lunar New Year, and symbolism with like the Asian diaspora. And then I noticed like Asian students 
would trust me more because they saw that I was able to, I guess, do the legwork or the beginning understanding and they would fill in the blanks for me.

Denise used her ability to learn more about other cultures, to build connections with students and advocate for their specific needs.

Other job responsibilities included crafting and facilitating trainings, using social media to engage commuter students, and campus outreach. Not included in her job description was the cross-campus relationship building aspect of her role. She used this tactic to garner support for initiatives she wanted to accomplish. She said,

I feel like a large part of my job, and I don't know if this is technically written down or not, was like the relationship-building component, or what I feel like might be said in other words like the politicizing um of diversity education. So, what that kind of looks like is a meeting with different department heads and kind of being able to get buy-in an a lot of the things that I wanted to create or do.

Rapport building was a key factor to help Denise implement new initiatives in her office.

\section{Sharice Jones}

Being a Black woman, there are certain things that your other colleagues, at least that's the most salient identity for me-your other colleagues can get away with, who have different identities from you. Um I know this is said a lot, having to work twice as hard, um which is, I think it's true. (Sharice Jones)

Sharice Jones is in an especial role. Her position as Assistant Director of Residential Life

- Social Justice Initiatives at a large research university in the southeast is a dual responsibility role. She oversees residence halls and she is the social justice appointed professional for the department.

Born and raised in the deep south of the United States, Sharice grew up in a blue-collar household. Her father was a Deacon and worked at a tire company and her mother, who was a 
"praying Black woman" and a Sunday school teacher, picked cotton for a living. Growing up, Sharice traced her father's family tree all the way back to 1794 in Marion, Alabama. She described herself as a "nerd kid" growing up because she researched her family, but it was important and still is important to her to know from where she came.

When she was six years old, her family moved across the country to another southern state where she lived much of her life. Although her parents lived "paycheck-to-paycheck", Sharice said that she and her sister never went without. Her parents made sure they had a "good life" and a "nice home to come back to."

As a first-generation college student, Sharice learned how to apply for college and student loans on her own but equates much of her success in that process to Black women in her community who mentored her. Her Black female guidance counselor connected with a representative at a nearby university and got the application fee waived for Sharice. Sharice attended that university for her undergrad and graduate career.

In college, Sharice was a resident assistant and majored in history as she had aspirations to become a teacher. During her junior year, she tried to pass the teaching exam but did not pass the math portion. She dropped teaching from her course load, picked up two minors, and applied for graduate school in Student Affairs at the same university. When it was time for her to start graduate school, she received notification that the university dropped the Student Affairs program and offered her a spot in community counseling, instead.

Pathway to diversity position. Sharice's "diversity" journey began in graduate school. She was a graduate hall director, a member of the campus' NAACP Chapter, and was a volunteer at an international center at another local university in the area. Because of her grandparents' involvement in the Civil Rights Movement, she understood what it meant to advocate for 
underrepresented groups. By working with the NAACP and the international center, she was also able to advocate. The Black students on campus in NAACP wanted someone who cared about them and who would help advocate for them. Some international students never worked with a Black woman before, so Sharice was their first introduction. In that space, they all learned together.

Sharice worked full-time with residence life at a prestigious university in the Midwest after she graduated with her master's degree. She spent a few years there before she saw the opening for her current position, Assistant Director of Residential Life- Social Justice Initiatives. The Social Justice Initiatives aspect of the role was brand new, and Sharice was eager for the opportunity to use her background in residence life and her skills in diversity, education and advocacy.

When she began the role, she was responsible for social justice initiatives for the Residential Life Department. Residential Life is housed under the umbrella organization of Housing; however, that changed. Sharice said, "but you know, stuff happens, and you become responsible for the whole department." Two months into her position, there was a racial incident that occurred, and Sharice had to "clean up the mess." There was another incident during a book club session where a White male said the word "nigger" and the department called Sharice in to handle it. Finally, there were other racially charged incidents which happened on the housing and operations side and the director "voluntold" Sharice to address the situations. She is currently responsible for social justice initiatives for the entire Housing and Residential Life Department.

Job Responsibilities. Sharice's Assistant Director of Residential Life job responsibilities includes overseeing residential communities with under and upper-class students and students who live in Greek affiliated housing, supervision of four full-time hall directors, the indirect 
supervision of graduate students, and the facilitation of professional staff trainings for approximately 400 professional staff members in the department. If there is a hall director vacancy, Sharice takes over their building and their job responsibilities while maintaining her own workload.

Simultaneously, Sharice's social justice initiatives role is incredibly time consuming. She is the consultant for all the entities under the Housing umbrella for diversity and inclusion (D \& I) related incidents. She creates and revises policies and procedures for those entities regarding D \& I, trains and facilitates workshops for the department, and serves as the housing representative for the university-wide bias response team.

\section{Zion Johnson}

There have been like, really challenging points of where it's like, I'm a Black woman, but I'm a young Black Woman with locs. Um, and so I think the way in which I have to like position myself in certain places or like be strategic about like what I say um can sometimes just...it can be stressful. (Zion Johnson)

Zion Johnson is the Assistant Director of the Black Unity Cultural Center at a large research university in the Midwest. She started her position one year ago and is now transitioning to become the interim Director of the center. The current Director accepted a new position.

Zion and her family lived in the south suburbs of a large city in the Midwest during her formative years. From kindergarten to approximately sixth grade, Zion went to school with mostly Black and Mexican American students. When her family moved into another neighborhood, Zion and her twin sister went to a racially diverse school. She recalled the culture shock she felt when she noticed that her new classmates wore brands such as "Abercrombie", a brand often associated with a White clientele, and she wore "Roc-A-Wear", a brand associated with Black culture. Name-brand clothing was not the only cultural difference she noticed at her new school. The students "listened to the teachers" which was something that Zion did not 
experience at her previous school.

She successfully completed the rest of her educational journey at her new school until she graduated high school and went to college at a small private liberal arts university in the central region of her home state. Because her undergraduate institution was so small, Zion formed close relationships with her peers and professors. Professors actively stayed involved with their students and took extra time to ensure the students succeeded. For example, one day, Zion did not show up to class because it was raining, and she did not want to get her straight hair wet. Her professor called her on her cell phone, asked Zion why she was not in class, and then made her go to class. Zion appreciated the individualized attention because of the support from the professors.

Her graduate experience, however, was not the same. She moved across the country to attend a large-sized research one university on the west coast. That feeling of "culture shock" set in again during this time because the professors at this institution were not going out of their way for students the way the professors at her undergraduate institution did. Zion had to adjust to this new normal, but she said that because she had the individualized involvement from her undergraduate career, she learned how to navigate the large campus environment.

Pathway to diversity position. Zion's "diversity work" path began at her undergraduate institution. As a student leader on campus, Zion joined the Black Student Union and Student Government to advocate for Black student needs. She helped write policies to ensure Black students and students of color had a seat in the student government cabinet. When that policy did not pass, Zion and the presidents of other cultural organizations on campus formed a coalition. One rule of the coalition was that if a student wanted to be on the executive board, they had to run for a Student Government seat. This was a way to put students of color back on Student 
Government to help with policy reform.

These skills helped Zion prepare for her role as a graduate assistant in the Diversity Office in the College of Education and her first professional career as an admissions counselor after graduate school. She worked in admissions for one of the branch campuses for her current university. In this position, she developed expertise in recruiting students from underrepresented backgrounds to attend the university. Transitioning from admissions to her current job as Assistant Director (AD) of the Black Unity Cultural Center was easy as one of the job requirements for the $\mathrm{AD}$ role was to work with admissions.

Job Responsibilities. Zion's primary duties as AD are the supervision of student interns, serving on campus-wide committees, and office programming. Her position collaborates with other campus entities on programs for the students who use the center. One collaborative program with a ministry group on campus emphasizes that "rest is a form of resistance" during times of turmoil. Unfortunately, because of the COVID-19 pandemic, they canceled the event.

Another responsibility of Zion's role is educating the campus community about various identities in the African diaspora. Her goal is to showcase the many ways there are to be Black in this world and at the university. She continued,

A big part of my work is making sure that we aren't telling a single narrative story about Blackness in general, um and that we're really against disrupting narratives that there is one way to be Black on campus.

By doing this, she ensures that they center the voices of Black women and Black Queer individuals.

Zion's position works closely with admissions. Zion's background in admissions gives her the tools her to advocate for admissions to recruit more Black students. She said she can 
speak with her admissions colleagues about how to be more inclusive in their recruitment practices.

\section{Researcher's Note: A Familial Connection}

As the participants shared their stories with me, many of them mentioned their families and how their familial ties helped shape their experiences as they came of age. During the institution of slavery, family units looked different for Black families compared to Whites. Enslaved Blacks had no way of "keeping" their blood relatives because White people owned them. Collins (2000) stated that Black people formed extended families with other enslaved Blacks on the plantation not only as a way to resist but "to redefine themselves as part of a Black community consisting of their enslaved 'brothers' and 'sisters"” (p. 49). We see this extended family tie in Jade's story as she notes that her grandmother raised her and the familial connection that her grandmother had with the surrounding neighborhood community. Freeman and Logan (2004) found that despite the separation of Black families, they shared "common roots" or "values and traditions" to maintain familial connections. Some of these traditions were "oral storytelling from elders who expressed and passed on wisdom” (Freeman \& Logan, 2004, p. 11), and we saw this mimicked in Nubia's story about her family. Nubia's father passed on the tradition of understanding what it meant to be Black and proud of it, and Nubia's Black pride is what steers her in her work life. Sasha's family is full of educators and they wanted her to seek a career in education. Although Sasha went against their desires and studied pre-med, she ultimately came back around and entered the world of education. Family influence and socialization is an integral part of these women's narratives. 


\section{Section Two: Emerging Themes}

The previous section summarized each participant's background and their journeys into "diversity work." Despite the differences in their backgrounds, these Black women diversity workers discussed common experiences which emerged as themes in this study. Many of the experiences the participants discussed in their workplaces were similar. I used Black Feminist Thought as my theoretical lens through which to develop my four themes, and they also aligned with the literature reviewed in Chapter Two. As mentioned in Chapter Three, I used thematic coding (Maguire \& Delahunt, 2017) to find the common connections among the participant interviews. I read each transcript and listened to each recorded interview approximately four times, and I highlighted common phrases or words, and then I created a table in a Word document and listed headings for common themes. I took direct quotes from each participant and placed them under the initial codes. I then took the initial codes and combined them into themes and sub-themes for this section.

\section{Theme 1: Black Woman in Diversity}

As stated in the beginning of this chapter, Black Woman in Diversity were the words of Monica Shakespeare when she described how she felt when she received the job offer for her role. The participants, in some form, spoke about what it was like being a Black woman in a diversity role, the expectations they have for themselves as "diversity workers," and the expectation others have of them. Three sub-themes emerged from this: who belongs in the role, advocating for colleagues or students, and on the frontline. This theme connects to the Black Feminist Thought framework. BFT situates Black women in the historical context of how they were subjugated into labor specific roles, such as domestic work. Black women found that they were limited to these types of jobs and Davis (1981) affirmed this by mentioning that White 
women did not categorize themselves as domestic workers. The Black woman in diversity theme suggests the same. Black women "fit" into diversity roles at PWIs. There is an unspoken idea, Which was posited by the participants, that Black women belong in these positions.

Who Belongs in the Role. Monica, Skylar Rae, Bailey, Dr. Camille, Zion, and Nubia all expressed their views regarding who belongs in diversity roles. While they understand the need for the role, Monica, Bailey, and Zion mentioned that there was some skepticism on their part about being in the role and that other people expect them to just be a "diversity worker." Although the Vice President of Student Affairs (VPSA) asked Monica to take on the role, she was unsure if it was something she wanted to do because she believed that only Black women occupy these positions. Monica said, "I actually said that I would never work in diversity because I didn't want to be the Black woman in diversity. Because that's all you see. I'm just like, 'no, that will not be me."' Monica reluctantly accepted the role, but it was because she felt obligated to do so given the VPSA asked her. She questioned the VPSA's motivates in asking her to step into the role. She continued,

But, I mean, you know, when you're asked to apply something you have to take that option and take that chance and if someone sees good in you, then you know, you have to do it. But sometimes I do question I'm like, "hmm, did she do this because I am more of a safe person and I'm going to make sure that we focus more on inclusion and not, you know, get, [quote unquote], too, too in the weeds of things?" And you know make people question too much.

Monica's questions about being a safe person is called "institutional passing" (Ahmed, 2012). Institutional passing involves being the token minority in a diversity position who can "soften the blow and aims to not cause trouble...not being assertive" (Ahmed, 2012, p. 158). This 
is problematic because if an institution is solely concerned about hiring someone who will not cause "trouble", is the institution as committed to diversity and inclusion as they say they are?

Like Monica's perception of who occupies “diversity roles," Bailey said that her university constituents also believe that only Black women fit into this realm. This idea that only Black women can work in these areas makes Bailey feel as if she has to work harder to prove herself. She continued,

It's kind of like, because I am a Black woman, I am placed inside diversity, equity and inclusion work. So, it's like, “yeah, that's where you belong, because you're Black you belong in diversity, equity, and inclusion.” That's my experience with it. Just having to, as a Black woman, just having to prove myself. That feeling of going to work for them like you have to be 10 times better than the next person is a real thing. Bailey's point here is important because it outlined the pressure she feels as a Black woman diversity worker to perform, given others believe that this is the role she is supposed to be in.

Zion felt the same way. She said the campus community knows she works in the Black Unity Cultural Center, so when she attempts to advocate for initiatives outside of her role, campus partners often look to the Director, a White man, of the department that houses the cultural centers on campus for knowledge about other topics. Zion said,

So, the director of diversity education, is a White man. And I think like when we've been on panels together, and we're both talking about, like, diversity work and things like that, um... I don't know, like, when you get questions from the audience or things like that, it's more so like, directed towards him. Um, and, or like, he's asked to, like, be the leader of like, certain things, because they're like, "Okay, well, he has to be more credible, because it's not something that he has to care about, like, he's not a part of 
these populations." Whereas I am [part of a population]...and so I think like once February rolls around, then I'm seen more as like a credible speaker because it's like Black History Month. Um, but I think too, like sometimes being a Black woman in diversity work like I can be pivoted like just within this realm and not like being tapped for having other knowledge outside of just like diversity and inclusion.

Zion's perception of being a Black woman in her role resonated with Skylar's experience. Skylar said that when people first met her, they assumed she worked in the multicultural center. She said,

I think people assume because I'm Black that, I'm supposed to be working in diversity. So, when I tell them that I'm at the CDI, they're like, "oh, okay," like that's an automatic, right. And so that is like, okay, I could have been a professor, I could have been so much other things.

Skylar and Zion's points validate the Black woman in diversity theme's concept of only fitting into one role. It is as if Black women can only do diversity work.

Dr. Camille (Dr. C.) said she felt like she was under constant surveillance as a diversity worker, not only because she was the only Black woman in the Student Affairs Division, but because her colleagues expected her to always be accessible and responsive. This pressure added to Dr. C.'s stress about her position and depleted much of her energy to work with students. She noted,

We have a pseudo campus climate committee and in my head I'm like, "If I weren't there, people would ask where I was. People would wonder why I wasn't there as the director of the Black Center. So, I don't always feel like I get to opt out. And I want to opt out...and not feel pressure or feel like I have to be in spaces just because of who I am, 
which is one of the reasons why I'm like "How do people make it?" Like, I've definitely been thinking about and considering...just to be like a general Student Affairs person because then I won't be expected to be everywhere. But like when you're the diversity person or you're representing an identity, you're expected to be everywhere. So, yeah, and I just got used up, I went to everything I supported everyone. And then it just dwindled. And now it's just hard for me to get up. And that means other people who should be getting my good energy, don't. Like I also teach and I'm like my students are just not getting the best me, I feel really guilty about that because I'm preparing future Student Affairs people. And just not getting the best me.

That feeling of exhaustion was central in Dr. C.'s decision to leave that institution.

Nubia had a different perspective from Monica, Dr. C., Skylar, Bailey, and Zion. They believe that because they are Black women in "diversity roles," that they should be in the role. Nubia said that it "makes sense" that she is in her position. Although being Black is a huge aspect of her identity, Nubia does not think about it much in her current role. Her identity as a queer woman is more salient. She does, however, believe that there is an expectation that Black women should be in these roles. She said,

I'm finding it difficult to talk about my experience as a Black woman in this job. If I worked in like Career Services, I feel like it might have been a little easier because Career Services isn't um, at its core, diversity work. But I'm finding it difficult to try and separate them. Um, because as a Black woman, it makes sense for me to be in this role. So, I've never felt like you shouldn't be here. Or this is not for you. I've never felt any opposition to me in my role. I've never felt any opposition from me in my work. Maybe if we're talking about something specific and I'm like, "this is what transgender is" and 
people are like, "I don't believe in that." I've had that position but um, never about my existence at the institution and the role that I'm in. I've never had that. And I've never felt that. Because my work is...it's expected of me to be there.

Although Nubia believes she belongs in the role, she confirmed at the end of her narrative that there is an expectation that she belongs in the role as a Black woman.

Advocating for colleagues and students. Sasha and Jurnea viewed their positions as Black women "diversity workers" differently. They must use their roles to advocate for either other Black colleagues and colleagues of color or Black students and students of color. Jurnea's story is interesting because she said that she does not "think about being Black" when she is at work, but other people bring it to her attention, and because she is the only Black person in senior leadership in residence life, she advocates for the Black employees in the department. She explained,

And at this stage, I often recognize that the ways in which my race show up at work or in this predominately White environment is because of the experiences of those around me and my need to advocate on behalf of them. So, for example, the hall directors [of color] feeling their voices are not heard that they don't feel like our um again, this is just our context in residence life and it may bleed into all of Housing, or the university, but the way in which it does describe it, so often they don't feel heard they don't feel accepted, they don't feel like they can bring their full selves to work, there are mixed messages about the way that inclusion is actually lived out in the organization, um that we don't engage in true social justice work, etc. And so, while I don't have those personal experiences with our leadership team...I honor the fact that those are experiences that are real and valid for them. I find myself needing to advocate on the behalf of them. 
Jurnea recognizes the important of her existence as a Black woman diversity worker to assist other employees who do not share the same positive thoughts about the departmental cultural as Jurnea does. She is their sounding board and messenger to the rest of senior leadership.

Similar to Jurnea, in Sasha's current role, she uses her diversity position to support and advocate for others. Sasha meets with various campus partners to help students be successful when they may be in distress. She admits, however, that she has to be strategic about how she advocates for students because she is still new in her role. She wants to maintain working relationships with colleagues, and people may develop opinions about how she handles situations. She explained,

I'm very close to the housing director. I feel like a lot of times when things get to her desk and its students, she doesn't deal with them appropriately. I can't tell her that yet. I can empower my students on how to advocate for themselves. But in order to keep this relationship open, I can't just bombard her office and say "this is what you will do and this is how you will treat students"...like that strong advocation. Like, I have to still work within the system to help my students to train them because you know students have more power.

Sasha recognizes the importance of instilling leadership skills into her students in her position. This connects back to her reasoning for taking on her role so that she could help mentor students.

On the Frontline. Being a Black woman in a diversity position can be accompanied by unforeseen circumstances that could place them in unforgettable situations. Leaders asked Denise, Sharice, and Jade to respond to bias incidents that directly affect them as Black women at their respective institutions. While Sharice and Jade's incidents were direct racial bias situations on their campus, Denise's experience was a semi-indirect racial bias situation. A 
public White supremacist group leader who led the White supremacists march at the University of Virginia in Charlottesville, Virginia in 2017, came to speak at Denise's campus one semester. During that semester, Denise and her supervisor were the only two Black staff members in the Multicultural Affairs Office. Senior leadership asked them to help staff the event. This offended her. She said,

This guy is known for inciting a lot of hate, like, [the Dean said] "let's have some university staff there." And that trickled down then to, I guess, like contacting Multicultural Affairs. And then the two Black people, myself and my um assistant director, were the people asked to, like, be at this, like speech or whatever. And it's just thinking about, like, the fact that this person is like, well known for spewing hate speech specifically around racism and race...There's ...like five, six people working in the office at this time, and again, two Black people. And it's like, you're going to ask the both of us to put ourselves like in this...we're now supposed to just stand here and watch this person say hateful things about people that look like us, when, you know, it's just kind of that like we were clearly chosen, because it's like, “oh, let's put these like Black people, like around this atmosphere" to kind of be like, "oh, look Black people are here too." Or you know, like the university has Black people that could be a forefront for this type of thing, and it felt just very greasy.

The dean finally told them they did not have to attend the event, but the damage was already done. She continued,

I didn't know the full story of this guy even. And I'm like, after I was asked to do it, I'm like looking more up about this person. And I'm seeing like their history of just like hate speech around Black people. And it's like, really? Out of all the people in this 
office, you're gonna specifically station Black people at this like, all White event. And it's just like things like that. It's like you're not putting your staff safety, either emotionally, mentally or physically, you know, at the forefront, you're just trying to paint optics, you know?

Denise reflected on that event and questioned the motives of "diversity work" all together. She continued,

I thought to myself like, "Is this just how diversity work is? Are you supposed to like, capitalize on your identities in order to make things look a certain way or like push for, like an agenda?"...is it like, I guess that paranoia that people feel when they're being gaslighted or when something racist happens and you're like, "wait, was that racist? Or am I being whatever about this?" And then you're like, "no, that was frickin racist." Or like, "I'm being gaslighted." It was kind of like that process of like questioning myself a lot. And then getting pissed off at questioning myself. It's like, I am a rational person. I'm like thinking through the steps, thinking through like the bigger picture of like, what this looks like, and I'm just really upset about it. But I never really - other than to my supervisor - I never said really that....and I hate that.

Denise was upset that she did not speak up about the incident to anyone besides her supervisor. However, the reasoning for that could stem from the hostile work environment the White woman director created which she alludes to later in this chapter.

Given Sharice is now the "diversity worker" for the entire housing department, senior leadership asks her to intervene in a multitude of situations. She said that when she intervenes, it sometimes results in a White person "attacking" her or calling her "racist" for speaking on topics of race even if the group previously discussed race. As stated in her introduction, Sharice 
recalled a time when she had to co-facilitate a book club event where a White man said "nigger" at one meeting. She said that even after she tried to "fix" the harm done, things still do not change. Sharice shared,

And then, being asked to, co-facilitate the book club because someone said the N Word, and did not see any reason why, you know. So, our new executive director wanted to get advice, right? And, you know, let's ask a Black woman what we should do, how should we clean it up? And when said Black woman gives you advice um that will help to um acknowledge it and not run from it, you don't do what you need to do. And then that causes more distress.

Sharice mentioned that if White colleagues spoke up more during these situations, things could change, but the support is not fully there. She said White colleagues and leadership speak up for "other" situations faster than they do about issues regarding diversity and inclusion.

As previously stated in Chapter One, Ahmed (2012) said that "becoming the 'race person' you are the one who is turned to when race turns up" (p. 5). Sharice, the Black diversity person, experienced being the one who her department leadership named permanent champion to fix all the racial issues for every facet of the department.

Jade, too, felt pressure to respond to bias incidents on campus. Jade, however, spoke about responding to bias incidents while already having much on her plate at work. She said that she feels "exhausted" and lacked the energy to give students the support they yearned for after the most recent racially charged event on campus. She shared,

I'm exhausted and there's been a lot of hate related incidents like Blackface on our campus that literally amplified student activism and student Black female activism in a certain way. Um, student athlete activism and I've been at the center of that, not alone 
with my boss, and right like my team, but it's literally just has been like I'm exhausted and I can't. Then, I'm supposed to be responsible for student lives.

She continued to say that while there is an expectation to support her students, there is also an expectation that she continues to be highly functioning in the other aspects of her role. She further said,

I don't have the energy to meet with students. Like in these one-on-one capacities. I literally have nothing to give and the work gets tired. But the fact that like, I think the work is still supposed to be done in a very high capacity way. It's almost like "y'all trippin like this is unrealistic and an unstable," you know, to be at the crux of all this and still be expected to do the things and the way Black women are supposed to give life and take care of other things.

What Jade described here is the "myth" (Harris-Perry, 2011) or the "controlling image" (Collins, 2000) of the mammy. The mammy is supposed to take care of everyone else before herself. The foundation of the mammy figure began with Black women caring for White children during the institution of slavery and spilled over into the post-antebellum period when Black women served as domestic workers. Collins (2000) explained that mammies always know their "place as an obedient servant" (p.72). Collins (2000) continued,

The mammy image also serves a symbolic function in maintaining oppressions of gender and sexuality...Juxtaposed against images of White women, the mammy image as the Other symbolizes the oppositional difference of mind/body and culture/nature thought to distinguish Black women from everyone else. (p. 72) Jade is fully aware of the unrealistic expectations placed on her by leadership to serve students and manage the full scale of her role in her cultural center. Dr. C. would say that Jade 
was "mammying the babies" as Dr. C. said this during her interview when she expressed how tired she was from all the work on her plate and the expectation that she takes care of students' lives, too.

However, Jade recognized that "other mothering" is a part of her role. Other mother is a concept Collins (2000) described as caring for other children that are not one's own. It derives from the familial ties of kinship during the antebellum period. The Black students are not Jade's biological children, but they are her children as the parameters of her position place this expectation on her. She feels a responsibility to make sure they feel supported on the predominantly White campus.

Being a Black woman "diversity worker" comes with its challenges and triumphs. It is difficult to navigate predominantly White environments when campus constituents only see them "fitting" into a diversity role like Zion, Monica, Dr. C., Bailey, and Skylar expressed. It is also concerning when there is an expectation to be the spokesperson for all biased incidents like Denise, Jade, and Sharice. In contrast, Jurnea and Sasha use their stature as Black women "diversity workers" to help advocate for other colleagues or students of color to help them advance. With all the "ebbs and flows" (good and bad) (Zion Johnson) of being a diversity worker, the Black women in these roles often find themselves "standing in a crooked room" (Harris-Perry, 2011).

\section{Theme 2: Standing in a Crooked Room}

Harris-Perry's (2011) "standing in a crooked room" analogy operationalizes the experiences of my participants. Many facets of our society have racist and sexist ideals about Black women. Black women in diversity roles are not exempt from these distorted images. We have "bent" and "shifted" in these crooked rooms to debunk preconceived stereotypes about who 
we are, in predominantly White spaces. Two sub-themes emerged from data analysis:

respectability politics and imposter syndrome. Both sub-themes describe how these women "bent", "shifted", or viewed themselves in their work environments as diversity workers.

Standing in a crooked room as a theme aligns with the BFT framework because BFT offers a glimpse into the distorted mirror into which Black women have historically looked. These distorted images or stereotypes of Black women are the mammy, jezebel, and the sapphire (Collins, 2000). These racist and sexist images still persist in the work environments of Black women diversity workers and cause them to alter who they are to perform their job responsibilities.

Respectability Politics. While the participants did not call respectability politics by name, they mentioned code-switching, which is a symptom of respectability politics. Black women developed respectability politics to resist the distorted images of their sexuality and protect themselves from "sexual assault" (Cooper, 2017). Perhaps it was a way to protect Black women's identities. In this study, some participants understand respectability politics all too well, as they can point out when and why they "shift" who they are in their work environments.

For Sasha, Jurnea, and Sharice, it means that they adjust the way they deliver messages to groups of people in various settings. They used the term "code-switching." Code-switching is when someone "alternates between two or more languages" in various settings (dictionary.com, n.d). Sobers' (2014) Black women participants code-switched in their predominantly White environments. Code-switching can be a tool to "hide the pain, frustration, or struggle they may be experiencing from university staff, administration, or faculty making it more difficult to recognize when they need support" (Sobers, 2014, p. 52). Sasha, Jurnea, and Sharice each spoke about instances when they had to think about how individuals would receive the message they 
tried to communicate in their predominantly White environments. Interestingly, for Sasha and Sharice, all of their responses centered on trust and wanting to protect Black women's image in the workplace. If they lacked trust for groups of people, they would code-switch while being mindful of how others may view all Black women. Code-switching could be a tool for their survival in their work settings. Sasha said,

So, one thing in this is that, and I hate to say it like this - in some ways, until you can experience and see the underlying pieces of people, how departments work, how they respond. You almost have to, not dumb down, but not let them know you know as much as you know.

Sasha furthered mentioned code-switching when she advocates for her students. In the aforementioned section, she discussed advocating for a student with the housing director. She said that she had to decide how she would speak to the housing director, so the director did not view her in a negative light. She mentioned,

If I were to go in there and be like "this is what you're going to do, and this is how you're going to do it," they're going to automatically put you in a category of, "she doesn't work inside the system...she's a rebel." That's how it will be identified with me and I know those things...because I do have an opinion that's strong and I do have a certain type of thing but I feel like with me still being a year in, I still have to get a better footing here. I have to get up a network and identify what my network is because if I jump out too soon.... and for the wrong reasons, they'll dismiss the overall effort of what I'm trying to do, if that makes sense.

Sasha's idea of her colleagues labeling her as a rebel is similar to the sapphire controlling image of Black women. The sapphire is the angry Black woman (Collins, 2000; Harris-Perry, 2011) 
"one that characterizes them as shrill, loud, argumentative, irrationally angry, and verbally abusive" (Harris-Perry, 2011, p.87). Sasha is cognizant of this stereotype and navigates her environment strategically to communicate with colleagues.

Sharice confirmed Sasha's sentiments about code-switching. She recognized that she is a representative of Black women to some, and she must think strategically about how she handles certain situations so others cannot associate Black women (and men) with negativity. She said she does not want others to "judge them unfairly".

Sharice posited that trust is key when she communicates with individuals. If she does not trust the individual, she code switches.

And having and noticing in certain meetings, how I have to code-switch. What am I okay with saying, and how it's going to impact me down the future? Who's at the table, who's in a room? Even with my multicultural environment group. We have so many different people, even though they say it's a "safe space," I don't feel like it's a safe space. Regardless, cuz there's people who don't look like me at that table and its people who do look like me, you have still got to be careful.

She said she must be careful because she does not know how her words or her actions can affect her, long-term, with those relationships.

Jurnea mentioned code-switching from a unique perspective. Jurnea prides herself on her educational background. She attended "affluent" institutions of higher education so her ability to code switch has nothing to do with how others view Black people. Her code-switching derives from how she communicates with other people of color because of her educational journey. She explained,

I'm often in my head about "all right, how do I give feedback um as a Black woman to 
another person of color?" I know that my management style might be different from theirs, my understanding of environment, like how you show up at work, um what you look like, how you dress, um, how you speak. And I've gotten challenged to think differently about that. Where I've been educated in these very like affluent areas, [they] believe themselves to be the "Ivys" of the west of the Midwest, if you will, like, they're very specific ways in which you show up, and when people don't show up that way I internally am processing like "okay, how much of this is my stuff as a Black -probably slightly classist- individual?" So, thinking about those intersecting identities.

Jurnea's educational background from affluent predominantly White environments shaped her views regarding how Black people should "show up" in predominantly White environments. This idea of how to "be" is centered in Whiteness. BFT laments that White domination shaped our ideals about what is "normal" and anything which deviates from that is “other" (Collins, 2000). Jurnea's classist thinking of how to "normally" show up allowed her to view other Black people and people of color's ways of expressing themselves as "other."

Zion's "code-switching" is a little different from the other women. She said that she is a "young Black woman with locs" and like Sasha, Sharice, and Jurnea, she has to "be strategic" about what she says and when. It is stressful for her to think about this continuously. However, Zion's code-switching also derives from her choice of attire. She pays special attention to what she wears to work when people make comments about her attire. She names the practice of respectability politics as the cause. She said,

Something that I always think about, like being a Black woman in higher ed is honestly the clothes that I wear...I'm always like, “Okay, well I don't want to wear this because I don't want like somebody to make a comment about it or like my skirt goes to my knees 
and like me [having] whole talks with myself around like respectability." So, it'd be like a whole thing and I'm like, "I'm just gonna get dressed, go to work." And I don't think that it's something that other people have to deal with. Or, I'm like, okay, “does this shirt go to my collarbone?” or lowkey I be like “do I look too cute," right? Because I don't want this to interfere with work that I'm trying to do. I've received like, different comments like, "oh girl...thats tight" or "you got that on?" So, that for me like almost those comments like in certain spaces, try to discredit the work that I'm trying to do based off of like an outfit.

Zion's thoughts about how she represents herself at work is not a new concept as Black women developed strategies to resist racist and sexist ideals about their bodies and their sexuality. In the late 1800s and early 1900s, The National Association of Colored Women (NACW) had to navigate through many distorted images about who they were, in the name of politics. Cooper (2017) continued,

The intellectual project of situating Black women as knowledge producers and human entities worthy of political consideration cannot be reduced to a conversation about Black women's obsession with systems of sexual representation. Race women had to comb through a morass of sexual misrepresentations in order to make Black women visible on more socially sustainable terms. They sought to construct the race woman intellectual as a foil to the sexually deviant Black female specter that haunted the American political imagination. For these women, the fictive social narratives of Black women's sexuality intruded upon the facticity of Black women's intellectual ability and interests. But the fact that race women deployed a combination of strategies of respectability, dissemblance, and embodied discourse suggests that they were less 
interested in evacuating all modes of sexual expression from the social terrain of the Black female body and more interested in making sure that ideas of sexuality did not overdetermine and limit the scope of Black women's social possibilities. Thus, they concerned themselves with creating a body of thought and a series of social strategies that would shift the public discourse about Black women's bodies. (p. 41)

For Zion, it was more than just being persnickety about what she wore to work. She, like the women in NACW, wanted to ensure that her body and the way she dresses does not overshadow the work she does and her intellectual ability to serve in her role.

But the objectification of Black women's bodies did not begin with the NACW. One of the first instances of body objectification of Black women was in the 1800s with Sara Baartman, an African woman who had a large butt and enlarged labia (LaVoulle \& Ellison, 2017). Europeans paraded her around Europe and exploited her body in circuses to prove to the world that Black women were sexually licentious and inferior to White people (LaVoulle \& Ellison, 2017). Understanding this concept may also be cause for why Zion ensures she is not "too cute" at work to disrupt others' preconstructed ideals about her body.

Imposter Syndrome. While some participants used respectability politics as a tool to maintain relationships, others like Jade and Dr. C. found that imposter syndrome was at the crux of their roles as diversity workers. Many instances when they felt like imposters, involved feeling overworked and their inability to always be available for students during times of crisis. They both said that they felt like imposters at the beginning of their roles.

Jade said, I had an imposter syndrome from the day I said, "yes." Um, because again, my 
work [previously] was embedded in diversity, but it wasn't on behalf of, right? And that wasn't what I was hired to do. And so, I was like "they done hired your girl and I don't really know what's about to happen."

Dr. C said [referencing being selected over an internal candidate] And because I had never done it before [been in a diversity position], I also, you know, had some imposter syndrome around that too like "well11ll, can I? like am I going to be what students need?" Like "can I connect with them in the ways they need or want?" Like my lived experiences are completely different [than theirs].

As their careers progressed, leadership tasked them with "taking care" of the Black students on top of their job responsibilities. While they both love their students, the expectation from university leadership to continue to do all of their other work overwhelms them.

Jade said, I low key just feel like sometimes I'm a fucking failure. And other times I'm like, wow, I'm the realest nigga in the room only." And it's a struggle because sometimes I want to be in the middle and I don't know how to find that balance, because I'm just exhausted or over programmed or um I feel like I'm running and haven't slowed down since I started. And I'm possibly in year four sooner than I think, you know. I would say that I'm more like, aware of what the fuck my role is, while also struggling with feeling like I was strong because I was in my first year when I had no baggage and no scars. I was mentally energetic and positive about everything to now being like, "Ooh, this is my third year in this relationship and I'm feeling a way." I can't say I'm pulling my weight $100 \%$ of the time even though that energy I feel like I am. But I don't know that I am, I think the imposter probably is weighing a little bit more heavy than it is now. 
Dr. C. said, I often feel frustrated that I haven't been able to connect and reach students in the ways they need. And I have a lot of guilt about that and realize that I'm on all these committees and I'm doing all these things. And I don't know if I'm making a difference.

So, I don't think anybody's ever heard of probably not listening to me but like I'm on the market right now. And so, my somebody else needs to come and do it because I'm not, I'm not doing a good job.

It was difficult for Jade and Dr. C. to effectively support their students due to the demands of the university. This feeling of inadequacy was the second factor in Dr. C.'s decision to leave the position.

In contrast, Jurnea also alluded to having imposter syndrome in her role because her colleagues view her as the "content expert." She said,

I think that I often question myself and that's that imposter syndrome. Do I know what I say I know? Because a huge part of my work in social justice leadership education, I'm often called upon to be a content expert...But I question, do I know enough? Am I conveying it the right way? Communication skills are huge to me.

Jurnea's imposter syndrome yielded to internal expectations of herself and not external expectations from those around her.

\section{Theme 3: Nail in a Tire}

The relationship one builds with their colleagues and supervisors help shape the way the participants in this study view their experiences in their diversity roles. This theme, comprised of three sub-themes, explores the relationships the participants had with White women, Black women, and Black men. Some participants had lasting relationships with their colleagues while others lost all trust and confidence in theirs. My theoretical framework, BFT, aligns with this 
theme and all three sub-themes. BFT operationalizes how Black women's experiences, juxtaposed with White women's experiences, are vastly different, and it shows how White women play a role in the marginalization of Black women even in movements such as feminism (Collins, 2000). BFT posits that positive relationships with other Black women are a form of resistance and offer a sense of community, as Black women find their collective voices. In contrast, there are instances were Black women may not get along well. Finally, BFT exposes the differences in the ways in which Black women and Black men experience their racialized lives. Although Black women and men share the same racial identity, being a woman encompasses a higher likelihood for marginalization and, thus, subjected to victimization far more dehumanizing than Black men have had to experience. Black men have also historically been able to suppress Black women's intellectual contributions to uplifting the Black race (Collins, 2000). The narratives of the participants contribute to the ideas of BFT.

White Women. When discussing the relationships between the participants and White women, my participants' stories were either positive or negative, with little variation in between. Jurnea and Skylar described their relationship with their White women supervisors as strong. Jurnea worked with her supervisor for approximately ten years, and she trusts and feels supported by her. She believes that their ten-year relationship allows her supervisor the privilege to say "off color things" to her and she does not take offense to it, but other colleagues may find her comments harmful. She continued to explain,

I feel like my peers, or [hall staff] folks of color might be like "you gon let her get away with that? How dare you let her say..." I'm like, "I'm good. Now, whether or not you feel comfortable about it, you know like, I'm fine.” But I think in my mind I'm always like second guessin...my mind is always kind of running. If I let her say this and I don't check 
it, other people will think that that's why the climate of the organization is X... I know her intentions. I know the work she does, I know the sacrifices she makes it to ensure that we have an inclusive organization. So, I'm good. Now, if you're not good I think you need to get to know her as an individual. That doesn't necessarily make it right or wrong, as it Relates to other individuals.

Jurnea understands that her supervisor means well and encourages her colleagues of color to build a rapport with her supervisor on a personal level to understand that she is a good person.

Skylar bonded with her supervisor early in her position. They went to a conference together on Skylar's first day of work. They connected and learned about each other during the trip, and they maintained that relationship afterwards. Skylar said that her supervisor even helped her find a place to live.

Bailey, Sharice, and Monica's relationships with White women are different from Jurnea's and Skylar's. These women all mentioned the disconnect they have with White women in their workspaces. Sharice said "it's crazy that she would rather have a White man than a White woman as a supervisor" because the relationships with White women are bad. Dr. C. had several supervisors during her time as director and she said that the White woman did not understand Dr. C.'s role, and it was hard to connect with her. Monica's direct supervisor, a White woman, expects Monica and her coordinator to always be physically present in the office even though they have an administrative assistant. Monica said that pressure makes her feel like a "slave" in the office. In addition to feeling "like a slave", Monica also said that her supervisor does understand the responsibilities of Monica's role and her office, and it makes it difficult for Monica to connect with her. Finally, Monica says that her supervisor "feels threatened" by her. She continued, 
I mean, people say like "she's threatened by you, like, you know, you have to be careful she thinks you'll take her job." I don't know what she does, so I can't take her job...You know when you have your one on ones like if she says something that you notice that isn't right, then you try to help her...I see it as helping but she sees it as being combative. Even in my yearly evaluation she put that I was passive aggressive...Basically my head I'm hearing, "you're being the stereotypical Black girl and you're hard to work with.” So, the fact that my evaluation was like a slap in the face, because no one else on this campus would ever say that.

Monica's narrative about her White woman supervisor aligns with the literature about the stereotype of the "sapphire," the angry Black woman who Collins (2000) and Harris-Perry (2011) operationalized in their works.

Bailey's relationship with White women does not differ from Monica's. Bailey does not trust them.

God gon' have to really deliver me because I don't like White women. I don't- I don't trust, I don't trust White women. And of course, this is my experience, I don't want to generalize and say I don't trust all, because there are some that I do trust but for majority, I don't trust White women. White women have made me feel like a secondclass citizen for the four to five years that I've been in higher education. I have to constantly adapt to the way that they work - they're working styles.

Bailey believes many Black women in the field have the same collective voice about White women. She discussed,

I think if you got Black women together, to where we were truly vulnerable without fear 
of losing our jobs that we will have a shared community and saying that White women have been a huge issue for us in our field.

From a Black feminist perspective, it is important for Black women to have their individual voices to share their experiences as a form of resisting societal images about who they are (Collins, 2000) and we discovered that throughout these narratives in this chapter. However, like Bailey mentioned here, there is power in Black women's collective voices. As Black women curate their own stories, many of their stories overlap. This “group-derived Black women's standpoint” or collective voice is "crucial to Black women's survival” (Collins, 2000, p. 98). Knowing this, what would be the outcome if Black women, like Bailey, banded together to discuss their collective experiences with White women? Collins (2000) posited that the groups Bailey speak of are ones in which Black women can feel safe and "- they form prime locations for resisting objectification as the Other" (p.101). The women can use the space to truly express their pain caused by White women.

A collective voice is how the Combahee River Collective (CRC), a group of Black feminist in the mid-1970s, banded together to write a statement about the position of Black women's political position in the United States. They identified the "interlocking systems of oppression" that Black women experienced compared to the issues of White women centered feminism that ignored the racial issues of Black women, compared to the Black liberation movement which targeted the needs of Black men (Taylor, 2017). Taylor (2017) said that, "in this context, the women of Combahee were not only making a political intervention into the feminist movement, but by doing so, they were also creating new entry points into activism for Black and brown women who would have otherwise been ignored" (p. 98). They used their collective voices as a form of resistance to the marginalization of Black women's positions. 
Black Men. Similar to the White women sub-theme, the participants' stories about the relationships they have with Black men colleagues or supervisors are incredibly opposing. Nubia, Zion, Bailey, and Denise all reported to Black men at some point in their diversity careers. Nubia and Denise found a solid relationship with their supervisors. Both women spoke highly about the relationships they had with their supervisors. Nubia spoke about the collaborative nature of her boss and his kindness. She said he relied on her help at the beginning of his tenure in the role because she was familiar with the office. She said,

He's pretty uh democratic in the way that he runs the office and supervises, you know, asking for everyone's input and seeing how things work. And also, because I'm the most familiar with the office and the history of the office, and specifically the LGBTQ center and everything. And so, um he relies on some of my previous knowledge and experience with the area of how did this go before and what was this going on before? And what is the history behind this that we do this now? And all that kind of stuff. Nubia's Black male supervisor trusted her to help him guide the office, and he was supportive of her in her identities as a Black woman diversity worker. This trust allowed the two to build a solid relationship.

Denise talked about the support her Black male supervisor gave her when leadership asked them to work the alt-right event on campus. She said he also advocated for her on many occasions to his director supervisor, a White woman.

Zion said that sometimes she feels supported by her Black male supervisor and other times she does not. When discussing their supervision styles, she recalls a sexist comment he often made about how she handles situations. She said, 
He'll make comments like, “okay, Zion's the warm and fuzzy one, and I'm the person who's going to like, you know, be strict.” I'm always just like, “you know, am I nice and warm and fuzzy? Sure. But I can also right, like, get things done or like, make sure my student workers are held accountable for like different things.” And so, he and I have like had to have those conversations, like I said a few times since I've started.

Zion also shared that her supervisor only cared about programming for one group of students. Zion shared,

One of the comments that I heard coming in was that he was really just interested in like programming for like, Black male identifying students on campus. Um, and so I mean, I've definitely like seen that...I understand that that's like a passion area for you, but like within our roles, we can't just do like what is our passion area. And so how are we like supporting all of our students? So, trans students on campus, like what does programming look like for them within our community? Um, women, etc. So, yeah, I think our conversations are like helpful for like a little bit and we have to like revisit it when other things happen.

Zion's comments about her supervisor aligns with Cooper's (2017) notions regarding how Black men intellectuals in the $19^{\text {th }}$ century would monopolize race specific initiatives and suppress Black women's intellectual contributions.

Although Bailey passionately communicated her distrust for White women supervisors, she also had a negative experience with a Black male supervisor. A Black male supervised her when she was the Director of Diversity Programs. She said she had a misogynistic encounter with her supervisor, given he conducted his work unethically, and when she tried to report the situations, people ignored her and said that she was "too young" to understand. 
Black women. Several women spoke highly of their relationships with Black women, as colleagues, in a supervisory capacity, or as mentors. Sharice had many Black women, early in her educational career, who helped her achieve the success she has today. She credits many of her accolades to them. When Bailey was a graduate student, her supervisor, who was a Black woman, served as a mentor to her. Bailey's supervisor helped her navigate diversity work and still serves as a resource today, in her professional career. Nubia informally gathers with a group of Black women monthly on campus for lunch to stay connected with them. Denise found community with other Black women colleagues on campus when she experienced hardships in her job. Finding community was important to her because of the common experiences Black women often have on campus. She said,

I always kind of find being like a Black woman or wherever you go, there's

like, sometimes like a little club of like, "hey, you're a Black woman. I'm a Black woman. Let's talk about how all these other folks are doing whatever."

Here, Denise alludes to the need for Black women to have a sense of community and support in predominantly White spaces.

Dr. C.'s Black woman supervisor was not a suitable fit for her. She described her supervisor as "messy" as she "caused [her] more harm than [she] ever anticipated." Her Black woman supervisor aided in Dr. C.'s decision to job search. Not long after their relationship began, Dr. C. believes human resources terminated her supervisor.

\section{Theme 4: Just Tryna' Make It}

The final theme, just tryna' make it, is a metaphor for how Black women cope and navigate their roles. The data analysis process revealed that the participants cope and navigate using therapy, spirituality, and personal motives. The BFT framework acknowledges the ways in 
which Black women have resisted racist and sexist environments throughout history.

Challenging systems of oppression through writing and coalition building are just a few ways Black women cope with and navigate hegemonic environments (Collins, 2000). Jade uses therapy to cope with the stress she experiences from work. Monica referenced her therapist multiple times during the interview process. She credits her therapist with helping Monica "deal with" her White woman supervisor and explore ways to communicate with her. Thereafter, Monica realized that her therapist was teaching her how to make her White woman supervisor comfortable, and Monica decided she did not want to spend her time doing that anymore. She now spends her therapy time talking about other happenings in her life outside of her supervisor.

Monica has dual coping mechanisms. Along with therapy, she uses her faith in God to manage her daily emotions. Garner (2004) defined spirituality as "the creative practice by which Black people interpret, respond to, shape, and live out their understandings of divine reality and culture in the context of racial, political, and social oppression and life in general" (p. 5). Monica has a prayer on the wall in her office that she reads for encouragement. She said,

I'm super religious in the fact that like whatever I'm doing, I'm doing for God, so it's kind of like he's the one who's looking out for me so as long as I'm doing what I'm supposed to do, I'm good. I don't have to worry.

Monica takes time to recenter and reconnect herself with God, to ensure she can effectively perform her job duties. In her interview, she said the only reason she made an effort to navigate through her role as a diversity worker is because she is pursuing a doctoral degree, and the university pays for her tuition. She leans heavily on her coping mechanisms so she can finish her degree. 
The other nine participants use personal motives to either cope or navigate their positions effectively. For Nubia and Sasha, they navigate their positions by staying organized. Nubia uses her calendar, consistently, to manage her responsibilities. Like Nubia, Sasha also finds it important to stay organized. Therefore, she posts sticky notes on her office walls to remember minor details about her position.

Jurnea and Sharice use diversity and inclusion tactics to navigate their work environments. For example, Sharice understands that her department needs to work to increase their diversity and inclusion initiatives, so she uses her position to advocate to human resources (HR) regarding hiring practices. She partners with HR to review interview questions and hiring practices to ensure they hire people who are "equity and inclusion minded" to change the culture. She said,

Working with HR, we're talking about, you know, where are we advertising our jobs? What questions are we asking? How are we introducing equity inclusion work in orientation? How do we tell them this is a value of ours? So, in a way, trying to think of policies and procedures that will last, regardless of um how long certain people are there, but starting to make that a part of the culture without changing everything...It's more than having a conversation it's actually putting equity inclusion in our policies and how we run our department.

Like Sharice, Jurnea seeks input from diverse individuals during decision-making processes. She stated that, although she is the "diversity person," she understands that multiple perspectives inform the work she does and that "education feeds education." She includes differing viewpoints to help advocate for the staff of color who rely on her to speak up on their behalf to senior leadership. She stated, 
I told you how I feel about being a Black woman currently in my leadership role. I felt like for the most part on most days, I'm good. So, if my role as a diversity leader manager is to represent all of the needs, I have to be engaged with those who do not have the same experience that I do so I can best represent them.

Jurnea and Sharice's willingness to advocate for diversity at an institutional level are examples of what Ahmed (2012) said is a characteristic of diversity workers. Ahmed (2012) stated, Diversity workers, thus, spend a lot of time identifying the people in an organization who are willing to speak up about diversity...they have to be very mobile: willing to speak to all university employees, willing to attend any meetings...diversity work thus requires an intense form of physical and institutional mobility. (p. 31-32)

The participants demonstrate their willingness to speak up about diversity for the betterment of the organization and its members.

Zion and Denise both mention that they use forms of mindfulness to cope with their work environments. Zion named mindfulness, directly, and said that she communicates with her boyfriend after work about her day and uses a meditation application on her smartphone to help her with breathing exercises. These present moment experiences demonstrate to her that she must learn to "let things go" and "choose her battles." She said,

Similarly, when Denise faces challenges, she makes a present moment decision to let things go. Denise said that her former work environment was so bureaucratic that she quickly learned when and when not to speak up. She shared,

Just trying not to um I guess not to do the behaviors that I saw other people do before me that received backlash, which was stressful, right? Because then you're like, in your head about like, the things that you're like saying or doing in front of who...The big thing was 
like in staff meetings. If the director [a White woman] is saying something you don't say anything like an opposing opinion. I would even say, don't disagree definitely. But like, if an opinion "A" is thrown out and if you said an opinion " $\mathrm{B}$ " or just another option, it would be seen as like defiant, which obviously looking back and like going through these things, it's a lot of cult theory to me, you know, I watch a lot of Scientology documentaries. And so, like I know the steps. So, my knowledge also from like, cult theory, it was like, “Okay, cult leaders don't like to be like challenged in front of like members." And so, I guess that as a behavior.

Finally, Skylar and Dr. C. both use authenticity to navigate or cope with their work environments. For Skylar, she relates to her Black students who come from homogenous Black communities and now work at predominantly White institutions. She talks to them about her transition from a multicultural environment in the South to the upper Midwest.

Dr. C. admitted that she does not take any time for herself because she does not have the energy from all that she encountered in her position. Her way of coping and navigating her work environment is "waking up and putting [her] feet on the floor." Even doing that minor action used much of her energy.

\section{Cross-Cultural Analysis}

At the conclusion of the research process, I noticed similarities and differences in the participants' experiences. For example, all of the women had similar understandings that there were areas in which their institutions or departments lacked in their commitment to diversity by citing instances of discrimination or hostile work climates regardless if they worked in housing and residence life or multicultural affairs departments and centers. Another similarity was that regardless of how many years the women worked in higher education, each of them consciously 
found ways to stand in a crooked room and cite respectability politics as ways to navigate their predominantly White institutions.

The most tenured in the profession were Dr. C. with five years and Jurnea with eight years. Their experiences were both different and similar. Jurnea had great relationships with her White supervisors, while Dr. C. did not. Dr. C. discussed experiencing much distress from being a diversity worker while Jurnea noted mainly positive experiences. Both Dr. C. and Jurnea did, however, allude to the privilege they had in their roles. Although not mentioned above, during her interview, Dr. C. mentioned having "light skin privilege" as a Black woman regardless of her experiences with racism and sexism. Her lighter skin gave her access to certain conversations that other Black women might not have been privy to at work. Davis (2017) said colorism began during the antebellum period, and it granted light skinned enslaved Blacks access to work in the master's house while darker skinned Blacks worked the fields. Lighter skin is often associated with Whiteness and viewed as less threatening and trustworthy (Davis, 2017). Above, Jurnea stated that she is "slightly classist" when she described the expectations she has for other Black people. Jurnea's expectations of other Black people is similar to the classist "lift as we climb" motto of the NACW (Cooper, 2017). Cooper (2017) stated that "clubwomen both acknowledged class differences and thought in complex - though critically insufficient - ways about how to ameliorate the effects of those differences through their race work" (p.53). For Jurnea, she recognizes her privilege but makes an effort to advocate on the behalf of her Black colleagues, her way of lifting as she climbs.

\section{Conclusion}

Black Feminist Thought (Collins, 2000) posited that Black women are curators of their own stories and create their own consciousness in a world that historically marginalizes them. 
My interviews with the eleven Black women participants gave them a space to center their experiences as "diversity workers." Their personal narratives helped the reader contextualize who they were, individually, and why they chose their career doing diversity work in higher education. The four themes which included Black woman in diversity, standing in a crooked room, nail in a tire, and just tryna' make it, outlined similar and contrasting experiences each woman encompassed in her roles. This chapter outlined themes for Research Questions 1-3:

1. What are the experiences of Black women professionals who work in diversity positions? What aspects of their roles influence those experiences?

2. How do these experiences affect Black women's ability to perform the daily tasks of their roles?

3. What strategies do these women utilize to effectively perform their job responsibilities? Chapter Five addresses Research Question Four: What can colleges and universities do to improve the work environments for Black women serving in diversity roles? This question is highlighted in the recommendations for practice section. Chapter Five also discusses the conclusions as well as needs for future research. 


\section{CHAPTER V - FINDINGS, RECOMMENDATIONS FOR PRACTICE, AND FUTURE RESEARCH - Y'ALL GOTTA DO SOMETHING!}

For us, true speaking is not solely an expression of creative power; it is an act of resistance, a political gesture that challenges politics of domination that would render us nameless and voiceless (hooks, 2015b, p. 8)

The purpose of this study was to explore the experiences of Black women who work in diversity-related positions at predominantly White institutions (PWI). Specifically, this study focused on Black women in diversity positions in housing and residence life and multicultural affairs departments and centers. Using a qualitative research approach and narrative inquiry design assisted in telling my participants' full stories. I used Black Feminist Thought (BFT) (Collins, 2000), as my theoretical lens to guide this research. BFT was the appropriate framework for this study because it effectively operationalized these Black women's experiences. Previous research about women of color in diversity roles targeted chief diversity officers (Maraña, 2016; Nixon, 2013; Stone, 2018); however, there was limited to no research that centered on Black women in diversity roles who are not chief diversity officers. Thus, this study filled the gap in the literature.

My positionality regarding the research fueled my desire to study this important topic. Predominantly White colleges and universities often hire Black women to do "diversity work", but we can fall victim to the issue we are hired to "fix." Ahmed (2012) stated that institutions hire for these roles, to show that they "do diversity", but they do not care about it at all. As an experienced "diversity worker", myself, I have had firsthand experience with this ideology. Four research questions guided this study:

1. What are the experiences of Black women professionals who work in diversity positions? What aspects of their roles influence those experiences? 
2. How do these experiences affect Black women's ability to perform the daily tasks of their roles?

3. What strategies do these women utilize to effectively perform their job responsibilities?

4. What can colleges and universities do to improve the work environments for Black women serving in diversity roles?

Chapter Four, identified four themes which addressed research questions one through three, Black girl in diversity, standing in a crooked room, nail in a tire, and just tryna' make it, while the current chapter addresses question four in the recommendations section.

\section{The Importance of Qualitative Research and Narrative Inquiry}

Using a qualitative research approach gave me the chance to understand how my participants chose a path to diversity work and how many of their family values shaped who they are today. According to Creswell and Creswell (2018), qualitative research "is an approach for exploring and understanding the meaning individuals or groups ascribe to a social or human problem" (p. 4). The authors say that people who conduct qualitative research look for meaning in their findings. Creswell and Creswell (2018) also noted that narrative research studies use the stories of participants and the researcher to find a collective voice.

While qualitative research from this standpoint is key to highlighting the voices of participants' stories from multiple perspectives, qualitative research as a methodology is rooted in Whiteness and placed Black women in the margins (Evans-Winters, 2019). We must acknowledge the ways in which Black women "bring our lived experiences into the research process" (Evans-Winters, 2019, p. 17) and how these experiences offer an oppositional gaze (hooks, 1992) to White ideologies regarding what qualitative research is and what constitutes knowledge. Black women are curators of their own knowledge, and it is imperative for 
qualitative research to highlight those nuanced experiences. This study was an example of this, and the key connection to my theoretical framework, Black Feminist Thought.

\section{The Importance of Black Feminist Thought to this Study}

Black women are familiar with curating their own and collective stories about their experiences and the environments that surround them. As bourgeois White women historically centered themselves as the gurus of feminism (Davis, 1981; hooks, 2000), Black women were excluded from such conversations. White women could not account for the race and class differences that Black women experience in their lives. As hooks (2000) suggested, Black women have always known what oppression looks like in the face of racism, patriarchy, and capitalism. Furthermore, the BFT framework opened the doors for individual reflection but also a collective consciousness (Collins, 2000; Evans-Winters, 2019) about being a Black woman “diversity worker.” According to Evans-Winters (2019), "a collective consciousness was less about individual salvation or individual strength and more about one's ability to mitigate and alleviate a shared burden, sort of speak" (p. 37). My participant, Bailey, alluded to this collective consciousness when she spoke about Black women gathering to discuss the harm caused by White women.

In addition to understanding individual and collective stories, Collins (2000) posited the importance of self-definition for Black women in the social and political realm of the United States and its significance to our collective survival. When Black women are silent about their experiences, it makes it easier for "dominant groups to rule because the seeming absence of dissent suggests that subordinate groups willingly collaborate in their own victimization" (Collins, 2000, p. 3). This study provided my participants a space to resist many of the racist and sexist factors that impacted how they performed their responsibilities as diversity workers. 
Bailey, Jade, and Denise all said that participating in my study was "therapeutic" for them, and they longed for a space to finally tell their stories.

Finally, Black Feminist Thought was imperative for this qualitative research study for my participants and me. Evans-Winters (2019) stated that,

Black women's (as the researcher and researched) experiences are at the center of analysis in the qualitative research process informed by Black Feminist Thought. The Black feminist qualitative researcher begins with reflections on her own lived experiences and brings those insights into the research process. She does not claim to be an expert on a particular research topic or subject; however, she does view her observations of the social world just as significant to the research process as that of other researchers and other participants in the research process (p. 20).

My experience as a Black woman diversity worker was the catalyst for my interest in exploring other Black women's experiences in these roles. I spent enough time and felt an immense amount of internal turmoil as a diversity worker and I longed for a community of support. I yearned to hear the voices of other Black women in these positions to help inform the future of higher education and the support for us who occupy these roles.

\section{Overview of Chapter V}

In this chapter, I present the findings from the individual narratives and the collective four themes presented in Chapter Four. I then offer recommendations for student affairs practice and higher education. Finally, I make recommendations for future studies regarding Black women in "diversity roles." 


\section{Findings of the Themes}

I conducted 11 individual interviews with my participants. From these interviews, four themes emerged: 1.) Black woman in diversity, 2.) standing in a crooked room, 3.) nail in a tire, and 4.) just tryna' make it. I discuss each theme along with relevant literature in this section. Three out of the four themes had their own subthemes, and I discuss those individually as well.

\section{Black Woman in Diversity}

The first theme, Black woman in diversity, posited that each participant had their own perception of what it was like to be a Black woman who works in a diversity-related position. Collins (2000) said that regardless of Black women's social status, they are intellectual beings and can recognize their own realities as truths. My participants used their experiences with being a Black woman diversity worker to articulate how they viewed themselves in the role and how others viewed them, how they advocated for students and staff, and how their positions often made them frontline workers.

Who Belongs in the Role. Many of the participants had an idea of who should occupy diversity roles. They all knew that Black women held many of these positions on predominantly White campuses; however, Monica, for example, did not want to accept a diversity role when asked because she did not want to be boxed in as the "Black woman in diversity." She knew that people would associate her with only that position. Bailey and Zion confirmed Monica's sentiments and believed they had to work harder than other colleagues to prove they were competent in other areas besides their diversity role.

Dr. Camille (Dr. C.) said that because she was the only Black woman in the division, it was hard for others to not view her as just the "diversity person." She was a Black director who operated a Black cultural center. She noticed that because she was the only Black woman and 
was responsible for a race-based center, she felt constant surveillance from her White counterparts.

Finally, Nubia was the only participant who thought being a Black woman in a diversity role was a good thing. She said she was "supposed to be" in the role because it "makes sense" for her to be in it. Nubia also never experienced anyone objecting to her being in the role.

These are not the first instances of Black women "looking" like they belong in certain positions. As mentioned in the literature review, Black women occupied many of the domestic work positions because of racist and sexist ideals which determined those were the roles in which they belonged. Davis (1981) posited that White women opposed domestic work because Black women historically occupied those positions. Today, many people of color perform “diversity work" (Ahmed, 2012) on campuses. Understanding the connection between domestic labor and diversity work, Black women fit into the stereotypes of who belongs in these roles.

Advocating for Students and Colleagues. Jurnea and Sasha found themselves other mothering (Collins, 2000) and mentoring as Black women diversity workers. Other mothers care for children who are not their own. Other mothering is not a new concept. Historically, Black women have cared for others within and outside of their family units and add to a shared community (Cox, 2017). While there is no clear definition of a mentor, Cupid (2020) and Allen, Poteet, and Burroughs (1997) said that, "serving as a mentor is an additional investment in time that goes above and beyond the mentor's formal job requirements" (Allen et al., 1997, p.71). Jurnea and Sasha take on the responsibility of caring for and coaching others. For Jurnea, the Black hall directors in her unit seek her out to help them navigate their alleged hostile work environments. Jurnea spends much of her time talking with senior leadership about the hall director's experiences and she also tries to offer advice to her Black colleagues regarding how to 
navigate those experiences. Sasha often stays late in her office to offer student support. She understands they navigate multiple life and academic challenges, and they look to her for care. Because Sasha such a strong rapport with her students, she tries to help them advocate for themselves while simultaneously advocating for them with her colleagues.

On the Frontline. Denise, Jade, and Sharice all shared egregious examples of how they had to or almost had to attend events that negatively triggered them. For Sharice, it was responding to the book club incident where a White man used the "N-Word" and she was tasked to mediate the situation. As a result, her colleagues accused her of being racist. Members of Denise's leadership team requested that she and her Black supervisor staff an event that featured a White Supremacist leader. Denise feared for her safety and questioned the role of diversity work. Jade's institution experienced an incident during which someone dressed up in blackface, and Jade had to handle it. Becoming the "race person" in diversity roles (Ahmed, 2012) can place Black women at a crossroads between having to respond to racist events that could potentially affect them as a racialized person and institutions often turning to Black women to fix these issues.

As evidenced from the findings of these themes, I, too, believe that Black women heavily occupy these roles and because of that, we carry a tremendous amount of responsibility on our shoulders. We must support all of the students and staff of color, respond to all of the diversity crises, and potentially put our own safety at risk (Denise and Sharice) to meet the needs of the organization. This is a concern because, in addition to those experiences, we still have the associated experiences of being a Black woman at a predominantly White institution. At PWIs, Black women often feel marginalized and boxed in, which makes us believe we need to adjust our behavior to make others comfortable with us. Being a diversity worker does not exempt us 
from racism and sexism. I argue that our very presence in the role makes us more of a target for it. Ahmed (2012) lamented that the majority of people who occupy diversity roles are people of color and institutions hire for these roles just for the optics to show external constituents that they support diversity, not that they actually care to do diversity work. Historically, Black women have experienced both racism and sexism (Collins, 2000; Cooper, 2017; Harris-Perry, 2011), and when we become diversity workers, we have occupied roles that institutions may not fully support. We then carry the burden of trying to not be too aggressive or assertive about what we teach in our roles because even the word "'aggression' attached to a Black body carries the weight of a history, becoming a form of racial baggage" (Ahmed, 2012, p. 159). Understanding this in the context of predominantly White institutions is important because Ahmed (2012) said that people of color are already a threat, "pose a problem, or appear 'out of place' in the institutions of Whiteness" (p. 162). There are already preconceived notions about who we are as Black women, especially at PWIs.

\section{Standing in a Crooked Room}

The participants in my study revealed that they alter their personalities in their predominantly White environments. This crooked room analogy (Harris-Perry, 2011) emphasized Collins' (2000) definitions of the controlling images society has about Black women as mammies, jezebels, and sapphires. In this crooked room, Black women try to stand upright as they navigate the socially constructed stereotypes about who they are. My participants used respectability politics and experienced imposter syndrome because of being in their crooked rooms.

Respectability Politics. Respectability politics formed as an oppositional gaze to racist and sexist ideals about Black womanhood in the 19th century with groups like the National 
Association for Colored Women (NACW) as they worked for the racial uplift of Black people in America (Cooper, 2017). Because these women used a public platform to speak up and out about the Black race as "public intellectuals," Cooper (2017) suggested these women used respectability as a way to combat the stereotypes about Black women's sexuality.

The participants of this study used respectability politics in their roles to navigate their work environments. They identified code-switching and monitoring their appearance as techniques they practiced to make their colleagues comfortable. Protecting a Black woman's image was important for Sharice and Sasha. They believed code-switching would help alleviate negative ideas their colleagues may have had about Black women. The participants were willing to alter who they were for the good of others. Sasha understood that if she did not code-switch, her colleagues would think she was a "rebel" or the "angry Black woman", and they would be less receptive to hear what she had to say. Their actions symbolized the historical community support Black women have for each other (Collins, 2000). This unmitigated support is an act of resistance and interrogates hegemonic socially constructed ideologies about Black women. It is the same way "race women" (Cooper, 2017, p. 46) in the 19th century used their platforms as intellectuals for racial uplift.

Conversely, Jurnea code-switches when communicating with other Black counterparts who may not have had the same "affluent" education she did. She acknowledged that her "Ivy" education trained her to pay attention to how one dresses and how one speaks, and she admitted that she is "slightly classist." The literature suggests that Jurnea's thoughts about her class status is not a new concept among Black women. In Cooper's (2017) book, she uses the works of Mary Church Terrell and Fannie Barrier Williams to discuss the juxtaposition of middle-class Black intellectuals and lower-class Black people. Cooper (2017) stated that the NACW's motto of "Lift 
as We Climb" showed distinct class differences among Black people and noted that researcher Kevin Gaines believed that “"Black elites' claims of class differentiation were self-serving in accepting oppressive constructions...placing a moral stigma on poverty” (p. 51). Jurnea’s ideas of how one should present themselves at work is representative of the class divide among the Black community. She acknowledged that she has been "challenged to think differently about that" in the past.

Zion identified respectability politics as a form of survival for her as a diversity worker.

She spent extra time in the mornings getting dressed for work and critiqued her clothing. She did not want to look "too cute" and ensured that she was not showing too much skin. Zion's actions are representative of the years of Black women's sexual exploitation (Davis, 1981; Harris-Perry, 2011) and the years of us being in an antagonistic relationship with sexual politics. As aforementioned, scholars such as Davis (1981), Cooper (2017), and Harris-Perry (2011) all identified the ways in which Black women have not had sole ownership of their bodies due to White supremacist ideals about them being promiscuous and their sexual exploitation during the confines of slavery. These stereotypes spill over into the higher education realm and adds an extra burden for Black women in diversity roles.

Imposter Syndrome. According to Clance and Imes (1978), women who experience imposter syndrome "maintain a strong belief that they are not intelligent; in fact, they are convinced that they have fooled anyone who thinks otherwise" (p. 241). Clance and Imes (1978) did not specifically mention if Black women were included in this study; however, this definition operationalizes the experiences my participants, Dr. C. and Jade, shared. Jade's imposter syndrome was demonstrated when her university hired her for the role. This was her first diversity position and she was not sure if she could do the work despite having done it on 
occasion in her past positions. After she settled into her current role, she felt the imposter syndrome again due to work overload and her inability to fully meet the needs of the students she was responsible for in her center. Dr. C. shared Jade's sentiments. Her former diversity position was the first diversity role she had, and she did not think she would be able to connect with students.

Both women felt an immense amount of pressure with work overload that took away from their time and dedication to students. Both felt guilty about the lack of attention they gave to students and Jade even said she felt like a "fuckin' failure" because of it and Dr. C. said she did not know if she was making a difference in students' lives.

Although Jurnea was confident in her role as a diversity worker, she said she only felt imposter syndrome because her colleagues expected her to be a content expert. This connects back to Clance and Imes' (1978) study on imposter syndrome as Jurnea briefly thought that she may not know enough when her colleagues looked to her for guidance regarding diversityrelated issues. She questioned her abilities because she wanted to ensure her communication messages were clearly expressed.

Given the context of the environments of many of the participants, I believe it is almost impossible to effectively perform the job responsibilities of a diversity position as a Black woman, unless you have a supportive team around you such as Jurnea and Skylar (presented in the next section). Although Jurnea alluded to having imposter syndrome and code-switching like other participants, her imposter syndrome did not equate to people in her role making her feel inadequate. Her idea of imposter syndrome was more internally driven than externally driven like Dr. C.s experience with imposter syndrome. When Black women diversity workers are in unhealthy work environments, they question their reasoning for being in the role (Denise), they 
feel overwhelmed and are unable to effectively support students (Jade and Dr. C), and they tonepolice themselves (Sasha). As a diversity worker, I, too, experienced instances where I could not adequately give students the attention they deserved because of my workload and imposter syndrome. There were many days when I struggled to get out of the bed in the morning like Dr. C. mentions in her narrative about how she coped with her day-to-day struggles.

\section{Nail in a Tire}

The third theme, nail in a tire, highlighted the varying relationships the participants had with White women, Black women, and Black men supervisors and or colleagues. The participants all had varying relationships with those three identity groups. Some valued the relationships they had with one or all of these identity groups while others believed people from those groups caused them harm in their roles.

White Women. Jurnea and Skylar had nothing but great things to say about their White women supervisors. Their supervisors took time to get to know them on a personal level which showed Jurnea and Skylar that they could trust them. Jurnea said that her and her supervisor had a ten- year relationship and, because of this, her supervisor knows her on a personal level and vice versa. Skylar and her supervisor bonded when they traveled to a conference together. This was the start of their trusting relationship. From these instances, one could infer that their supervisors were allies for them. A "White ally" is a person who recognizes their Whiteness, works on ways to use their privilege to dismantle systems that oppress marginalized groups of people, and promotes equity for people of color (Clark, 2019; Spanierman \& Smith, 2017). Jurnea did not specifically address her supervisor as an ally, but she described her supervisor as one who advocates for her on multiple levels and, thus, she is an ally for her. 
On the other hand, Dr. C., Sharice, Bailey, Denise and Monica all mentioned having negative experiences with their White women supervisors. Dr. C. and Monica both said their supervisors did not know what they did in their roles and were not equipped to supervise Black women in diversity roles. Monica even said that she felt like a slave in the office because of the expectations her supervisor places on her and her coordinator to always be in the office. Sharice mentioned that she would rather have a White man as a supervisor than a White woman, because past relationships with White women "were bad". Denise discussed how the White woman director in her Multicultural Center would become angry if anyone presented an opposing idea to her. Finally, Bailey greatly distrusts and does not like White women because they made her feel like a "second class citizen" and they expect everyone to adapt to their working styles. hooks (2015b) said,

Attempts by White feminists to silence Black women are rarely written about. All too often they have taken place in conference rooms, classrooms, or the privacy of cozy living-room settings, where one lone Black woman faces the racist hostility of a group of White women (p. 12).

Here, hooks (2015b) described the experiences my participants had or have with White women. White women's oppression of Black women in their roles is a form of hostility all participants share.

Black Women. For many of the participants, Black women colleagues or supervisors served as mentors or "safe havens" for them. Sharice spoke highly of the Black women in her life and noted that Black women helped her in different phases throughout her life and into her professional career. Bailey expressed the same gratitude. Her supervisor and mentor in graduate school helped her adjust to the school community and prepared her for her first professional 
diversity position. Denise found a community of Black women on her campus with whom to process her workday and bond. This community (Collins, 2000; Evans-Winters, 2019) allowed Denise and the other Black women colleagues a place to resist and share common experiences regarding what was happening in their work environments.

Dr. C. did not find that having a Black woman supervisor equated to a positive relationship. Dr. C. said that her supervisor caused her the most harm while she was Director. Soon after the relationship began, Dr. C. started on her job search journey.

Black Men. Nubia and Bailey raved about the positive experiences they had with their Black male supervisors. Nubia's supervisor trusted her to take responsibility for her own area as she had more history with the institution. She described him as a democratic leader and one who seeks input from the team when making decisions. Denise said that her former supervisor advocated for her on multiple occasions, but he really helped her when the university asked them to be representatives at the alt-right event.

Zion and Bailey had different views on Black male supervisors. Zion had mixed emotions about her supervisor. She had issues with his sexist ideals about her being "warm and fuzzy" when she responded to situations, and his patriarchal mindset of only wanting to program for Black male students for their Black cultural centers. Bailey also said that her supervisor made misogynistic and unethical comments. Although Black men and women share the same racial identity, Black men can still oppress Black women. Cooper (2017) posited that during the 19th century when the NACW was grooming Black women intellectuals, men from other dominant groups believed they were the ones who should speak for the entire Black race. Because of this, they placed Black women in the margins. Zion's experience with her supervisor aligns with 
Cooper's (2017) conceptualization that historically, Black men dominate the discourse about the Black experience.

The aspects of their roles which influence the experiences of being a Black woman in diversity and having to uphold respectability politics in the relationships with White women, Black women, Black men, and the egregious expectations placed on them from their departments. The theoretical framework, Black Feminist Thought (BFT) played a key role in developing this section of findings. BFT provides Black women a collective voice in sharing their experiences with the world around them, especially in situations where they historically have been silenced or marginalized. For example, Sharice, Monica, Dr. C., Bailey, and Denise's interactions with their White women peers or supervisors connect with the literature about the ways in which White women marginalize Black women (Taylor, 2017). BFT gave these women voices to collectively discuss the harm White women caused them and how it affected their ability to perform their jobs. As mentioned in my positionality statement in Chapter One, White people were the cause of my pain in my first full-time diversity position. White women in my office seemed to find joy in their ability to oppress me as a Black woman diversity worker. Similar to Bailey, it was hard for me to trust White women after that experience because I did not feel like they could be good people. Although these experiences of Black women with White women are not new, this phenomenon is significant because it demonstrates that PWIs do not make an intentional effort to protect Black women in these roles or offer consequences for racist and sexist occurrences. Jurnea and Skylar's White women supervisors, however, took the time to get to know them on a personal level which provided an opportunity for Jurnea and Skylar to trust them. It is admirable that the participants' supervisors connected with them, but a few 
trustworthy White women cannot account for the others who marginalize Black women. There has to be drastic changes made by PWIs to address this.

While Sharice and Bailey paid homage to the Black women who helped them in their professional journeys, Dr. C. recounted not having a good relationship with her Black woman supervisor. This difference in perspective demonstrated that while Black women do have a collective voice in their experiences, there are times when they do not (Collins, 2000). If there continues to be unrepairable relationships with colleagues such as Dr. C., Sharice, Zion, and Bailey had, for example, work environments for Black women will continue to be hostile and affect Black women's job performances and their willingness to remain in these roles.

\section{Just Tryna' Make It}

The last emerging theme, just tryna' make it, described the ways in which Black women cope and the strategies they used to navigate their work environments as Black women diversity workers. Spirituality, therapy, and self-motivation were some of the strategies they utilized daily. Monica and Jade both relied heavily on therapy to cope with the experiences they faced at work. Monica first utilized her therapist to help her process the relationship with her White female supervisor, but Monica decided to focus on other aspects of her life when she realized her therapist gave her advice on how to appease her supervisor. Navigating bias and discrimination have an effect on Black women's mental health (Jagennathan, 2018). Holmes (2014) said therapy assists people with managing anxiety and trauma and overall wellness. For Monica and Jade, therapy was a necessary tool to maintain and manage the stress they felt in their roles.

In addition to therapy, Monica noted that her faith in God helped her navigate the rough times. Monica keeps a message on her office wall about God, and she prays, faithfully. According to Shahid (2014), spirituality in the Black community began in Africa in the early 
seventeenth century. Garner (2004) stated that during the antebellum period, enslaved African women found ways to resist their masters and that spirituality "has been a source of renewal, survival, and resistance" (p. 5). Monica's faith helps her resist her hostile working environment as a diversity worker.

In addition to therapy and spirituality, Dr. C. Nubia, Sasha, Jurnea, Sharice, Skylar, Zion, Denise, and Bailey all use personal motivation to navigate their daily work environments. Nubia, Sasha, and Bailey all attested that staying organized helps them manage their workloads. Jurnea and Sharice advocated for diversity and inclusion initiatives within the human resources department and their colleagues in their departments. Both use this technique to make equitable changes for the betterment of the culture of the institution.

Zion and Denise use mindfulness techniques to stay grounded. On field note 7 (episode 7) of her Podcast, Writing What I Like, Evans-Winters (2019b) said mindfulness allows us to "quiet the mind." Zion uses an app on her smartphone to practice mindfulness and she said mindfulness, in addition to conversations with her boyfriend, helps her "let things go" or "quiet the mind" (Evans-Winters, 2019b). Denise had to use mindfulness when she tried to let things go. She began practicing this present moment experience when she noticed how overly bureaucratic her office environment was, and it taught her when to and when not to speak up.

Dr. C. and Skylar use authenticity to navigate their work environments. Skylar arrives to work as her authentic self to better connect with Black students who had similar life transitional experiences as she did. Dr. C. expressed that getting out of bed in the morning was the only way she authentically navigated her work environment. Her roles took much of her energy and she dreaded going to work most days. 
Sobers (2014) stated that, "the conversation needs to move beyond the safe spaces with one another. The secrecy is not working. The academy needs to know what it is like for a woman of color working in today's colleges and universities" (p. 166). Sobers (2014) said that it is great that Black women have a collective voice and can talk about their situations with each other in confidence, to feel safe, but we no longer should have to do that. The themes presented in my study highlighted the complexities of being a Black woman diversity worker and PWIs need to understand our position and take immediate action. No longer should we have to "shift" and "bend" (Harris-Perry, 2011) to make others feel comfortable around us. Gone should be the days when we must spend time worrying about what we wear so we can effectively perform our job duties. We should not have to find ways to cope just to get through a workday. The lasting effects of carrying these multiple burdens could potentially leave Black women with permanent scars. Denise and I are examples of women who have been emotionally scarred from being a diversity worker. Denise said that when she began her new role, she felt like a "battered puppy." When I was released from my first full-time position, I sat in a deep depression for four months until I started a new diversity job at another predominantly White institution in the South, and I felt that depression months into my new role. The themes presented here offer several pertinent implications for practice for PWIs moving forward.

\section{Recommendations for Practice}

Using the findings from the research participants' interviews, this section addresses Research Question Four, What can colleges and universities do to improve the work environments for Black women serving in diversity roles? Many of these recommendations derived from suggestions from the research participants. This section is split into two parts: recommendations for student affairs practice and recommendations for predominantly White 
higher education institutions, in general. Immediately following this section is recommendations for future studies regarding Black women diversity workers.

\section{Student Affairs Practice}

1. The Black women in my study want higher education administrators to listen to them. Many of them feel like one hears them when they talk about things going on in their dayto-day experiences as diversity workers. Denise mentioned that listening can resemble departments offering support focus groups for Black women in these roles and using that information to improve work climates for them. Nubia said that a part of listening means for the administration to consult multiple Black women when creating policies because often the administration will make changes that are not what Black women need. Bailey's idea of listening comes from her understanding that multicultural affairs is its own unique functional area. She said there needs to be policies in place that protect multicultural affairs. Sasha agreed and said that Black women must have a seat at the table because we bring a critical perspective, especially if there are discussions about student success.

2. The student affairs practice should also allocate more financial resources to the multicultural affairs departments and centers as well as diversity offices in housing units. There should also be more resources allocated for professional development. Many of these offices are underfunded. For example, Jade suggested that the Student Affairs division should automatically have professional development funds available to them. Her division of Student Affairs instructs her to pick one conference to attend a year and she feels like that is not enough. If they were allocated more resources, that would help their overall morale in the role. Jurnea agreed that more resources allocated to the professional development of Black women will aid in their continued success. Bailey said 
that funding multicultural affairs offices should be intentional, not rooted in "capitalism" thinking that "they're going to get something back" but with intention to support the efforts of the office and see Black and brown students retained and graduate.

3. Student Affairs divisions should assess the number of staff members in multicultural affairs departments and centers as well as diversity housing departments. In other words, they should provide additional staff member support given the number of students that Black women in these roles help or the multitude of tasks they facilitate (Sharice, Jade, Dr. C.). Jones et al. (2012) stated that Black women are more likely to have more responsibilities than their counterparts, and for the women in my study, this is true. Many of them expressed being overwhelmed with everything for which they are responsible.

4. The last recommendation for student affairs practice is for there to be a requirement that all members of the division commit to incorporating diversity and inclusion work into their job responsibilities. The participants believe that "diversity work" is not just their responsibility as full-time employees but the responsibility of everyone. One way Student Affairs divisions can do this is by implementing the Multicultural Organization Development Model (MCOD), an organizational assessment.

The purpose of the assessment is to get a clear picture of where the organization currently is and how far it has to go to become a multicultural organization. This step in the process also establishes a benchmark from which future progress can be measured. The process involves collection of three types of data (surveys, interviews, and audits). Ultimately, the Assessment phase is intended to hold up a mirror to the organization and allow the data to speak for itself. (Inspirus Consulting, n.d., para. 8) 
Once Student Affairs divisions complete the assessment, each department is responsible for setting short- and long-term goals to become a multicultural organization and then "diversity work" is distributed across the organization.

\section{Predominantly White Institutions}

1. The first recommendation for practice for PWIs is to pay Black women diversity workers a livable and an equitable wage for the work they do. As a director, Dr. C. said her former university paid her $\$ 20,000$ less than other directors. She said she knew that those directors were not "as tired as her" and she knew they were not "doing as much as [her] in terms of maintaining or trying to retain students and trying to develop humans" and that was "frustrating" for her to experience. Sharice echoed Dr. C.'s frustration with pay inequities. She said her housing department puts a tremendous amount of responsibility on her with "no extra pay." She continued, "I started seeing that pattern um as a Black woman, my White colleagues, you know, if they were asked to do a little bit more responsibilities, they're able to either get some more money or were automatically given that compensation, up front." Zion said that more pay is true equity.

2. A third-party consultant for the university is the next recommendation. Denise suggested that universities should hire someone "like a Shaun Harper," to come in and assess the culture of the university. She said that if employees are at the university for multiple years, they will not be able to see where changes regarding diversity and inclusion need to happen.

3. Predominantly White colleges and universities need ongoing diversity and inclusion trainings. Shulz et al. (2005) discussed training for faculty mentors to understand biases, etc., but the same can be said for many other university constituents. This can include 
anti-racism training and training on intersectionality (Crenshaw, 1989), conducted on a continuous basis which addresses the university's historical connection with racist practices and how they marginalize Black women. Williams (2013) said that diversity trainings will "ensure that inclusive climates extend beyond the classroom but into all aspects of campus life" (p. 398). These trainings should address structural racism head-on and not aim to make the White majority comfortable to check boxes to say they completed a training. These trainings should be intentional and used for transformational change throughout the organization.

4. A fourth recommendation for predominantly White colleges and universities is for them to evaluate their hiring practices. Campuses should audit the standard interview questions to ensure they are unbiased and to ensure there are questions that make candidates think critically about how they contribute to an inclusive environment and their work with diversity and inclusion efforts. This is not to mean that every new person hired is going to always get diversity and inclusion practices right, but this process will show that there is a commitment to it and that they are willing to continue their growth and development in it for the betterment of the university and its faculty, staff, and students.

5. Finally, there should be policies established to hold administrators and students accountable for their actions. In other words, all members of the university should be required to take on-going mandated diversity and inclusion trainings, and failure to do so should result in consequences. Also, when racist, sexist, or other biased acts occur, it should not be swept under the rug. Unbiased human resource members and university leadership should conduct full investigations. There should then be consequences for perpetrators as harsh as termination, for continued offenses. 


\section{Future Studies}

The findings from the research identified four critical future studies to further explore Black women's experiences in their diversity roles. The first study should center Black women in diversity roles' experiences at private institutions. During the recruitment stage of my research, I interviewed a woman named "Vivian" from a private institution. I did not know she worked at a private school until we were deep into the interview process. I did not include her in my study, but when I spoke to her, she revealed some of the same racist and sexist experiences as my participants from public institutions. She said that her experience "has been taxing especially when [she] tries to do things involving diversity and inclusion." There is no buy-in from the university regarding diversity and inclusion efforts even when she facilitates a program for diversity education. She also mentioned that her White colleagues negatively talk about her to students, and when she reports these incidents to human resources, the human resources department says, "we don't think these people want to change so how can we move you into another role?" It is important to study these women at private institutions, to have a holistic understanding of Black women's experiences.

I am also interested in studying the experiences of Black women in diversity roles at predominantly White institutions' experiences during the COVID-19 pandemic and after the murders of Ahmad Arbery, George Floyd, and Breanna Taylor, three Black people killed by law enforcement and White vigilantes. I interviewed Skylar, Nubia, Jade, and Zion after the country's quarantine mandate and campuses utilized virtual learning because of COVID-19. I want to know how they navigated their roles, online. As a diversity worker, I had to quickly shift and provide all diversity and inclusion trainings and programs using a virtual format. However, when the heightened racial unrest unfolded during the COVID-19 pandemic, I felt immense pain 
as a Black person and pressure from administration. While I grieved, I received numerous requests from White colleagues asking me to serve on different committees and task forces or asking me to help them have conversations with their Black students without asking me how I was doing in the process. If this was my experience, I am curious to know if other Black women had the same experience.

The third study should focus on the ways in which the entire higher education structure should be dismantled and rebuilt. I do not have the right answers regarding how to effectively achieve this, but it is important for it to be redesigned to include more diverse administrators, students, board members, and leadership in mind, initially. Thelin (2004) stated that higher education was designed for White, wealthy men and was a privilege that only they reaped. Women, Blacks, Natives, and other communities of color were barred from attending. As stated in the background section of Chapter One and in the literature review, once diverse groups of students (Black students) enrolled in higher education institutions, they understood it was a "structure of inequity" (Nzinga, 2020, p. 20) that marginalized them. If a system was originally designed for one group of people, then a rebuild is necessary to design a higher education system which benefits all groups of people. This would begin the first step in supporting Black women in all areas of higher education, especially in diversity roles.

Finally, since the conclusion of this study, I made the drastic decision to leave my diversity position in higher education that I received after my first full-time role. My decision to leave came at the height of the COVID-19 pandemic and the murders of the aforementioned unarmed Black people, as I was called to undertake more responsibilities for no additional compensation. This was not the first time I inquired about extra compensation because of the multiple programs under my purview, but COVID-19 and the recent events of racial injustice 
fueled my frustration for lack of pay. Given the university's inability to compensate me, I left the role for a new diversity position in the healthcare field. I am interested in studying the experiences of Black women in diversity roles in healthcare now given I will be positioned in this new field.

\section{Conclusion}

This study explored the experiences of Black women diversity workers in multicultural affairs departments and centers as well as housing and residence life at public four-year predominantly White institutions. Using Black Feminist Thought as my theoretical framework, I provided an opportunity for my participants to share their individual and collective stories about their experiences. From these stories, I found there were preconceived notions about who should be a diversity worker. First, there are distorted images regarding who Black women are, which has caused them to "shift" and "bend" (Harris-Perry, 2011) to debunk negative perceptions of them. Second, Black women's relationships with White women, Black women, and Black men are either solid or unmendable. Lastly, Black women must find ways to cope to perform their job responsibilities. This study fills the gap in the existing literature about Black women administrators and their experiences by understanding the complexities of a diversity worker. Predominantly White institutions can use the results of this study to improve work environments for Black women serving in these roles but also to make institutional changes regarding diversity and inclusion from top-down. This work has to be a priority and not performative.

Finally, as a researcher, this study helped me confront the trauma I held from my first full-time position as a diversity worker. Hearing and telling these women's stories showed me that I am not alone in this and it made me a better diversity worker because of it. I am no longer afraid to use my voice in my role to expose inherent systems of White dominance at 
predominantly White institutions, and I began teaching my students to do the same. PWIs must act with a sense of urgency to transform their institutional cultures to improve the working environments for Black women diversity workers. 


\section{REFERENCES}

Ahmed, S. (2012). On being included: Racism and diversity in institutional life. Durham and London: Duke University Press.

Allen, T. D., Poteet, M. L., \& Burroughs, S. M. (1997). The mentor's perspective: A qualitative inquiry and future research agenda. Journal of Vocational Behavior, 51, 70-89.

Arjun, W. A. E. (2019). Life at the intersection: Intersectionality, self-definition, and identity negotiation among Black women mid-level administrators at predominantly White institutions (Order No. 13811012). Available from ProQuest Dissertations \& Theses Global. (2209696574).

Armstrong, T. E. (2012). The hidden help: Black domestic workers in the civil rights movement (Order No. 1523640). Available from ProQuest Dissertations \& Theses Global. (1430931200).

Baldwin, C. P., \& Griffin, M. D. (2015). Challenges of race and gender for Black women in the academy. In De Welde, K., \& Stepnick, A. (Eds.). Disrupting the culture of silence: Confronting gender inequality and making change in higher education (pp. 55-66). Sterling, VA: Stylus Publishing.

Biondi, M. (2012). The Black revolution on campus. Berkley and Los Angeles, CA: University of California Press.

Brown McManus, K. C. (2012). We walk by faith, not by sight: An inquiry of spirituality and career development of Black women leaders in academe (Order No. 3545629). Available from ProQuest Dissertations \& Theses Global. (1240588405). 
Burke, M. G., \& Carter, J. D. (2015). Examining perceptions of networking among African American women in student affairs. NASPA Journal About Women in Higher Education, 8(2), 140-155.

Campbell, M. T. (2014). African-American chief information officers' career-path experiences: A descriptive phenomenological study (Order No. 3628907). Available from ProQuest Dissertations \& Theses Global. (1561152759).

Carter-Frye, M. (2015). An association case study that explores African-American female representation in higher education administrative leadership and executive roles (Order No. 10153739). Available from ProQuest Dissertations \& Theses Global. (1814766086).

Choates, R. (2012). In their own words: African American women narrate their experiences to leadership (Order No. 3516385). Available from ProQuest Dissertations \& Theses Global. (1029860319).

Clance, P. R., \& Imes, S. A. (1978). The imposter phenomenon in high achieving women: Dynamics and therapeutic intervention. Psychotherapy: Theory, Research and Practice, 15(3), 241-247.

Clark, M. D. (2019). White folks' work: Digital allyship praxis in the \#BlackLivesMatter movement. Social Movement Studies, 18(5), 519-534.

Crenshaw, K. (1989). Demarginalizing the intersection of race and sex: A Black feminist critique of antidiscrimination doctrine, feminist theory and antiracist politics. University of Chicago Legal Forum, (1), 139-167.

Crenshaw (1990). Mapping the margins: Intersectionality, identity politics, and violence against women of color. Stanford Law Review, 43(6), 1241-1299. 
Collins, P. H. (1986). Learning from the outsider within: The sociological significance of Black feminist thought. Social Problems, 33(6), 514-532.

Collins, P. H. (2000). Black feminist thought: Knowledge, consciousness, and the politics of empowerment ( $2^{\text {nd }}$ ed.). New York, NY: Routledge.

Colorado Mountain College. (n.d.). Residence hall vs dorm. Retrieved from https://reslife.coloradomtn.edu/new-students/res-hall-vs-dorm/

Cooper, B. (2017). Beyond respectability: Women, gender, and sexuality in American history. Urbana, IL: University of Illinois Press.

Cornelius, J. (1999). We slipped and learned to read: Slave accounts of the literacy process, 1830-1865. In Henderson, A. B., \& Sumler-Edmon, J. (Eds.). Freedom's odyssey: African American history essays from Phylon (pp. 9-25). Atlanta, GA: Clark Atlanta University Press.

Cox, G. (2017). Voices of Black women superintendents' experiences (Order No.10245219). Available from ProQuest Dissertations \& Theses Global. (1959337282).

Cupid, S. (2020). “It felt like home:” Exploring practices and mentoring experiences among Black doctoral women and black faculty women in sister circles at mid-Atlantic universities (Order No. 27958146). Available from ProQuest Dissertations \& Theses Global. (2409166905).

Davis, A. Y. (1971). Reflections on the Black woman's role in the community of slaves. The Massachusetts Review, 13(1/2), 81-100.

Davis, A. Y. (1981). Women, race, and class. New York, NY: Random House.

Davis, C. (2017). From colorism to conjurings: Tracing the dust of Beyoncé's Lemonade. Taboo: The Journal of Culture and Education, 16(2), 7-28. 
Delgado, R., \& Stefancic. J. (2001). Critical race theory: An introduction. New York, NY: New York University Press.

Dictionary.com. (n.d.). Code-switching. Retrieved from https://www.dictionary.com/browse/code-switching

Edgehill, V. E. (2007). Historical patterns of institutional diversity: Black women in race specific positions on predominantly White college campuses (Order No. 3283238). Available from ProQuest Dissertations \& Theses Global. (304851619).

Evans, S. Y. (2008). Black women in the ivory tower, 1850-1954: An intellectual history. Gainesville, FL: University Press of Florida.

Evans-Winters, V. E. (2019). Black feminism in qualitative inquiry: Mosaic for writing our daughter's body. New York, NY: Routledge.

Evans-Winters, V. E. (Producer). (2019b, July 2). Writing what I like [Audio podcast]. Retrieved from Apple Podcasts App.

Fox-Genovese, E. (1988). Within the plantation household: Black and White women of the. old south. Chapel Hill, NC: University of North Carolina Press.

Freeman, E. M., \& Logan, S. L. (2004). Reconceptualizing the strengths and common heritage of Blackfamilies: Practice, research, and policy issues. Springfield, IL: Charles C. Thomas LTD.

Galloway, S. N. (2012). African American women making race work in science, technology, engineering, and math (STEM) (Order No. 3512629). Available from ProQuest Dissertations \& Theses Global. (1024150524). 
Gardner, L., Jr., Barrett, T. G., \& Pearson, L. C. (2014). African American administrators at PWIs: Enablers of and barriers to career success. Journal of Diversity in Higher Education, 7(4), 235-251.

Garner, R. (2004). Contesting the terrain of the ivory tower: Spiritual leadership of African American women in the academy. New York, NY: Routledge.

Glesne, C. (1999). Becoming qualitative researchers (2nd ed.). Boston, MA: Allyn \& Bacon.

Glesne, C. (2011). Becoming qualitative researchers: An introduction (4th ed.). Boston, MA: Allyn \& Bacon.

Gray, S. (2017). To curl up or relax? that is the question: Tenured black female faculty navigation of Black hair expression in academia (Order No. 10266906). Available from ProQuest Dissertations \& Theses Global. (1946186752).

Green, B. A. (2019). When they see YOU: A case study comparing the lived experiences of vital faculty at predominately White institutions and historically Black colleges and universities related to diversity and inclusion of multicultural competence (Order No. 27700903). Available from ProQuest Dissertations \& Theses Global. (2315118852).

Gordon-Reed, A. (2018). America's original sin: Slavery and the legacy of white supremacy. Foreign Affairs, 97(1), 2.

Gupton, J. T. (2009). Pathways to college for homeless adolescents (Order No. 3368700). Available from ProQuest Dissertations \& Theses Global.

Henry, W. J. (2010). African American women in student affairs: Best practices for winning the game. Advancing Women in Leadership Journal, 30(24), 1-14.

Harris-Perry, M. (2011). Sister citizen: Shame, stereotypes, and Black women in America. New Haven, CT \& London, UK: Yale University Press. 
Harley, D. (2008). Maids of academe: African American women faculty at predominantly White institutions. Journal of African American Studies, 12(1), 19-36.

History Channel Website. (2018). Stonewall riots. Retrieved from https://www.history.com/topics/gay-rights/the-stonewall-riots

Hodges, C. R., \& Welch, O. (2018). Truth without tears: African American women deans share lessons in leadership. Cambridge, MA: Harvard University Press.

Holmes, C. M. (2016). The colonial roots of the racial fetishization of Black women. Black \& Gold: Vol. 2. Available from https://openworks.wooster.edu/blackandgold//vol2/iss 1/2 Holmes, L. (2017). 4 ways everyone can benefit from therapy. Retrieved from https://www.huffpost.com/entry/benefits-of-therapy-and-life-coaches_n_5635389 hooks, b. (1992). Black looks: Race and representation. New York, NY: Routledge. hooks, b. (2000). Feminist theory: From margin to center. London, UK: Pluto press hooks, b. (2015a) Feminist theory: From margin to center. ( $3^{\text {rd }}$ edition). New York, NY: Routledge.

hooks, b. (2015b). Talking Back: Thinking feminist, thinking Black. New edition. New York, NY: Routledge.

hooks, b. (2015c). Yearning: Race, gender, and cultural politics. New York, NY: Routledge. Howard, T. (2008). Who really cares? The disenfranchisement of African American males in preK-12 schools: A critical race theory perspective. Teachers College Record, 110(5), 954-985.

Hunter, T. H. (1997). To 'joy my freedom: Southern Black women's lives and labors after the Civil War. Cambridge, MA: Harvard University Press. 
Hylton, D. G. (2012). In her own voice: A narrative study of the persistence strategies of eight African American women vice presidents for student affairs at predominately White institutions (Order No. 3520478). Available from ProQuest Dissertations \& Theses Global. (1033785636).

Inspirus Consulting. (n.d.). MCOD: Multicultural organization development: The five questions you must address before attempting to initiate diversity, inclusion, and multicultural work. Retrieved from http://inspirusconsulting.com/tools-insights/mcodmulticulturalorganization development-five-questions-must-address-attempting-initiatediversity-inclusion-multicultural-work/

Jackson, A. P., \& Dorsey, M. R. (2009). Achieving against the odds: African American professional women in higher education. Bloomington, IN: AuthorHouse.

Jagannathan, M. (2018). What keeps some Black women from seeking mental health care and how therapists are working to change that. Retrieved from https://www.marketwatch.com/story/what-keeps-some-black-women-from-seekingmentalhealth-care -and-how-therapists-are-working-to-change-that-2018-12-18

Johnson, M. W. (2018). Historically Black colleges and universities as the unsung heroes of African Americans empowerment: A case study of the relevance for Louisiana public historically Black colleges and universities (Order No. 13419313).

Jones, T. B. D., Dawkins, L. S., McClinton, M. M., \& Glover, M. H. (2012). Pathways to higher education administration for African American women. Sterling, VA: Stylus Publishing.

Jones, T. B. D., \& Dufor, W. (2012). Direction along the path. In Jones, T. B. D., Dawkins, L. S., McClinton, M. M., \& Glover, M. H. (Ed.), Pathways to higher education administration for African American women (pp. 27-36). Sterling, VA: Stylus Publishing. 
LaVoulle, C., \& Ellison, T. L. (2017). Bad bitch Barbie craze and Beyoncé: African-American women bodies as a commodity in Hip-Hop culture, images, and media. Taboo: The Journal of Culture and Education, 16(2), 65-84.

MacPherson, T. A. (2011). Meanings of ebony: Politics and black self-identification among college women on predominately white campuses (Order No. 3466793). Available from ProQuest Dissertations \& Theses Global. (885430118).

Marina, B., Ross, S., \& Robinson, K. (2016). Voices from the margins: Illuminating experiences of African American women senior administrators in higher education. In Croom, N. N., \& Marsh, T. E. J. (Eds.), Envisioning critical race praxis in higher education through counter storytelling (pp. 89-106). Charlotte, NC: Information Age Publishing.

Marshall, B. T. (2017). Bringing ourselves to work: A narrative inquiry of LGBTQ professionals (Order No. 10760279). Available from ProQuest Dissertations \& Theses Global. (2021068333).

Maraña, J. A. J. (2016). The lived experiences of women of color chief diversity officers (Order No. 10250697). Available from ProQuest Dissertations \& Theses Global. (1867777302).

Miles, S. (2012). Left behind: The status of Black women in higher education administration (Order No. 3519353). Available from ProQuest Dissertations \& Theses Global. (1034453345).

Mills, C. W. (1997). The racial contract. Ithaca, NY: Cornell University Press.

Mitchell, M. L. (2018). They want a black face not a Black voice: The professional experiences of African American women middle-level managers (Order No. 10825031). Available from ProQuest Dissertations \& Theses Global. (2088057272). 
Moss, Y. (2014). The role of mentoring and career advancement: A phenomenological study examining Black female mid-level community college administrators (Order No. 3662311). Available from ProQuest Dissertations \& Theses Global. (1650557450).

National Center for Education Statistics. (n.d.). Fast facts: Degrees conferred by race and sex. Retrieved from https://nces.ed.gov/fastfacts/display.asp?id=72

National Center for Education Statistics. (2008). Table 249. Full-time instructional faculty in degree-granting institutions, race/ethnicity, sex and academic rank: Fall 2003, fall 2005, and fall 2007 [Table]. Digest of Education Statistics, 2008. Retrieved from https://nces.ed.gov/programs/digest/d08/tables/dt08_249.asp

National Center for Education Statistics. (2010). Table 256. Employees in degree-granting institutions, by race/ethnicity, sex, employment status, control and type of institution, and primary occupation: Fall 2009 [Table]. Digest of Education Statistics, 2009. Retrieved from https://nces.ed.gov/programs/digest/d10/tables/dt10_256.asp

National Center for Education Statistics. (2016). Table 315.20. Full-time faculty in degree granting postsecondary institutions, by race/ethnicity, sex, and academic rank: Fall 2011, fall 2013, and fall 2015: [Table]. Digest of Education Statistics, 2015. Retrieved from https://nces.ed.gov/programs/digest/d16/tables/dt16_315.20.asp

National Center for Education Statistics. (2017a). Table 306.10. Total fall enrollment in degreegranting postsecondary institutions, by level of enrollment, sex, attendance status, and race/ethnicity of student: Selected years, 1976 through 2016: [Table]. Digest of Education Statistics, 2016. Retrieved from https://nces.ed.gov/programs/digest/d17/tables/dt17_306.10.asp 
National Center for Education Statistics. (2017b). Table 314.40. Employees in degree-granting postsecondary institutions, by race/ethnicity, sex, employment status, control and level of institution, and primary occupation: Fall 2016. [Table]. Digest of Education Statistics, 2016. Retrieved from https://nces.ed.gov/programs/digest/d17/tables/dt17_314.40.asp

National Center for Education Statistics. (n.d.). Fast facts: Degrees conferred by race and sex. Digest of Education Statistics, 2016. Retrieved from https://nces.ed.gov/fastfacts/display.asp?id=72

National Partnership for Women and Families. (2018). Black women and the wage gap. Retrieved from http://www.nationalpartnership.org/research-library/workplacefairness/fair-pay/african-american-women-wage-gap.pdf

Nieman, M. (2013). The return on social bonds: The effect of social contracts on international conflict and economics (Order No. 3726759). Available from ProQuest Dissertations \& Theses Global. (1733644207).

Nixon, M. L. (2013). Women of color chief diversity officers: Their positionality and agency in higher education institutions (Order No. 3588822). Available from ProQuest Dissertations \& Theses Global. (1428435516).

Noble, J. (1993). The higher education of Black women in higher education. In Glazer, J., Estela, M., Bensimon, M., \& Townsend, B.K. (Eds.), Women in higher education: A feminist perspective (pp. 329-336). ASHE Reader Series. Needham Heights, MA: Ginn.

Pateman, C. (1988). The sexual contract. Stanford, CA: Stanford University Press.

Patitu, C. L., \& Hinton, K. G. (2003). The experiences of African American women faculty and administrators in higher education: Has anything changed? New Directions for Student Services, (104), 79-93. 
Patton, L. D. (2006). Black culture centers: Still central to student learning. About Campus, 11(2), 2-8.

Pinchback-Hines, C. (2013). From isolation to insulation: The impact of campus culture on the existence of two cultural centers (Order No. 3589549). Available from ProQuest Dissertations \& Theses Global. (1430909782).

Pope, R. L., Reynolds, A. L., \& Mueller, J. A. (2004). Multicultural competence in student affairs. San Francisco, CA: Jossey-Bass.

Price, J. L. (2017). "What's love got to do with it?": The master-slave relationship in Black women's neo-slave narratives (Order No. 10259376). Available from ProQuest Dissertations \& Theses Global. (1915943450).

Randolph, A.W. (2001). Fear of miscegenation: Black women educators in Columbus, Ohio, (1898-1909). In Mabokela, R. O. \& Green, A. L. (Eds.). Sisters of the academy: Emergent Black women scholars in higher education (3-28). Sterling, VA: Stylus Publishing.

Richardson, S. D. (2016). Exploring the socialization processes and resiliency of Black women regarding tenure attainment (Order No. 10251811). Available from ProQuest Dissertations \& Theses Global. (1870036770).

Robinson, J. L. (2018). Imposterized: The experiences of tenured and tenure-track Black women instructional faculty at California community colleges (Order No. 10825030). Available from ProQuest Dissertations \& Theses Global. (2076439223).

Rogers, I. H. (2010). The black campus movement: An Afrocentric narrative history of the struggle to diversify higher education, 1965-1972 (Order No. 3390516). Available from ProQuest Dissertations \& Theses Global. (305227447). 
Shahid, K. T. (2014). Finding Eden: How Black women use spirituality to navigate academia (Order No. 3670840). Available from ProQuest Dissertations \& Theses Global. (1646484637).

Shek, Y. L. (2013). Strategizing for the future: Evolving cultural resource centers in higher education (Order No. 3595250). Available from ProQuest Dissertations \& Theses Global. (1444159059).

Sobers, S. T. (2014). Can I get a witness?: The resilience of four black women senior student affairs administrators at predominantly White institutions (Order No. 3625189). Available from ProQuest Dissertations \& Theses Global. (1556553859).

Spanierman, L. B., \& Smith, L. (2017). Roles and responsibilities of White allies: Implications for research, teaching, and practice. The Counseling Psychologist, 45(5). 606-617.

Stanford-Randle, G. (2017). The enigmatic "cross-over" leadership life of Dr. Mary McLeod Bethune (1875-1955) (Order No. 10753614). Available from ProQuest Dissertations \& Theses Global. (2006954858).

Steckel, R. H. (1996). Women, work, and health under plantation slavery in the United States. In Gaspar, D. B., \& Hine, D. C. (Eds.). More than chattel: Black women and slavery in the Americas (43-60). Bloomington, IN: Indiana University Press.

Stone, P. M. (2018). How have female African American chief diversity officers (CDO) made meaning of the role political skill plays at predominately White research institutions? (Order No. 10744139). Available from GenderWatch; ProQuest Dissertations \& Theses Global. (2011012566).

Stulberg, L. M. (2018). LGBTQ social movements. Medord, MA: Polity Press. 
Taylor, K Y. (2017). How we get free: Black feminism and the Combahee River Collective. Chicago, IL: Haymarket Books.

Thelin, J. R. (2004). A history of American higher education. The Johns Hopkins University Press.

Urquhart-White, A. (2017). What does under his eye mean?: Language is a tool for oppression. Retrieved from https://www.bustle.com/p/what-does-under-his-eye-mean-inthe-handmaids-tale-language-is-a-tool-for-oppression-53409

Visser, S. (2015). Diversity and change in higher education: Examining the factors that foster or inhibit commitment to building institutional capacity for diversity (Order No. 3703612). Available from ProQuest Dissertations \& Theses Global. (1684090799).

Ward, L. W. (2017). Arguing race, advocating racism: A critical race \& discourse analysis of higher education race-conscious supreme court oral arguments (Order No. 10270591).

Watkins, P. L. (2018). Black women faculty: Portraits of othermothering (Order No. 11011131). Available from ProQuest Dissertations \& Theses Global. (2158095610). Watkins, W. H. (2001). The White architects of Black education: Ideology and power in America, 1865-1954. New York, NY: Teachers College Press.

Wesley, A. (2018). Managing multiple identities: The intersection of race and gender for Black female student affairs professionals in predominantly White institutions (Order No. 10750149). Available from ProQuest Dissertations \& Theses Global. (2029909536).

Wesleyan University. (n.d.). Black women and the Suffrage Movement: 1848-1943. Retrieved from https://www.wesleyan.edu/mlk/posters/suffrage.html\# 
West, N. M. (2011). The African American women's summit: A case study of a professional development program developed by and for African American women student affairs professionals (Order No. 3466832).

West, N. M. (2017) The African American Women's Summit: A student-affairs professional development Program. Journal of Student Affairs Research and Practice, 54(3), 329- 342 .

Whitehead, M. V. (2017). A phenomenological study of the barriers and challenges presented to African American women in leadership roles at four-year higher education institutions (Order No. 10269091).

Wiggins, T. S. (2017). An interpretive phenomenological analysis of the lived experiences and mentoring relationships of Black women student affairs administrators (Order No. 10684973). Available from ProQuest Dissertations \& Theses Global. (2029125066).

Williams, D. (2013). Strategic diversity leadership: Activating change and transformation in higher education. Sterling, VA: Stylus Publishing, LLC.

Williams, T. (2012). Job satisfaction of African American female faculty: The role of race and gender (Order No. 3551185). Available from ProQuest Dissertations \& Theses Global. (1287137112).

Wilson, C. A. I. (1998). A portrayal of the work life of tenured African-American female faculty working within historically White, public institutions of higher education in Virginia

(Order No. 3002496). Available from ProQuest Dissertations \& Theses Global. (250170286). 
Wolfman, B. R. (1997). Light as from a beacon: African American administrators in the academy. In Benjamin, L. (Ed.). Black women in the academy: Promises and perils. Gainesville, FL: University Press of Florida.

Woodlief, S. E. (2010). Out of the classroom and into the heart of the matter: A case study of university student residents' reaction to access to multicultural awareness education (Order No. 3428941). Available from ProQuest Dissertations \& Theses Global. (759853575). 


\section{APPENDIX A: RECRUITMENT LETTER}

I am a doctoral candidate at Illinois State University in the Department of Education Administration and Foundations. I want to investigate the experiences of Black women who work in diversity related positions at 4-year public predominantly white institutions (PWI) in the U.S. for one or more years. In this study, diversity positions will be defined as employment in housing, residential life, and/or multicultural affairs/centers. I would like to invite you to participate in this study. This study comprises two phases. In the first phase, I invite you to provide demographic information through a survey and in the second phase, you will be asked to participate in an hour-long one-on-one interview at your convenience. The interview will be either conducted face-to-face or virtually and will be audio-recorded. To consent to the survey, please complete the following form. https://forms.office.com/Pages/ResponsePage.aspx?id=OphfCGkLcEK3HRBpUHa6_iBtSQ_en KlKm-9V1id9yQFURjJZQzUxWEdPNDhMQUdCVzFNM1dLODZQVS4u

If you wish to participate in the interview, please send me an email at tristenjohnson1@gmail.com with the best times that work with your schedule so I may contact you.

If you know someone who may be interested in participating in this study or may have questions or concerns about this study, please email me at tristenjohnson1@gmail.com.

Thank you for your time and consideration!

https://forms.office.com/Pages/ResponsePage.aspx?id=OphfCGkLcEK3HRBpUHa6_iBtSQ_en KlKm-9V1id9yQFURjJZQzUxWEdPNDhMQUdCVzFNM1dLODZQVS4u 


\section{APPENDIX B: INTERVIEW PROTOCOL}

1. What is your full name?

2. What is your occupation and where do you work?

3. How long have you been employed in this role?

4. Where are you originally from?

5. Tell me about your background growing up

6. Tell me about your educational journey? How did you decide to work in higher education?

7. When did you begin doing diversity work? Why did you begin doing diversity work?

8. What has been your experience working at a predominantly white institution?

9. What is your experience as a Black woman diversity worker?

1. What aspect of your current position influence those experiences? Why?

10. How do your experiences influence the way you perform the daily tasks of your role?

11. What strategies do you utilize to effectively perform your job responsibilities?

12. What can colleges and universities do to improve the work environments for Black women serving in diversity roles

13. Is there anything else that you want to tell me that I may not have asked?

14. Do you know any other women who would qualify for this study? 


\section{APPENDIX C: LETTER OF CONSENT}

I am inviting you to participate in a research study about the experiences of Black women who work in diversity roles at predominantly white institutions (PWI). For this study, PWI means that $50 \%$ or more of the students attending the institution identify as white. I will be conducting this study for my doctoral dissertation and under the tutelage of Dr. Venus EvansWinters in the Department of Educational Administration and Foundations at Illinois State University.

Why are you being asked? You have been asked to participate in this dissertation study because you are a Black woman fulltime diversity worker in housing, residential life, and/or multicultural centers/affairs at a public 4-year, predominantly white institution in the U.S. You must have worked as a diversity worker for at least one academic year and must be 18 years or older. Your participation in this study is completely voluntary. You will not be penalized if you choose to skip parts of the study, not participate, or withdraw from the study at any time. What would you do? If you choose to participate in this study, you will be invited to a one-on-one virtual or faceto-face interview with possible follow-up conversations. The interview, which will be audiorecorded, will last approximately 60 minutes. The interview will be transcribed and shared with you for accuracy. Results from the interview will be presented without identifiers in the dissertation with, at times, quotes from our conversation.

Are any risks expected? Because you will be sharing your experiences doing diversity work at a predominantly white institution, you may have a risk of being triggered, feeling a multitude of emotions such as anger, sadness, happiness, etc. Should you face any of these risks, we will advise you to seek out self-care avenues such as professional counselors from the Employee Assistance Program (EAP) at your institutions or use your health benefits. 
Will your information be protected? I will use all reasonable efforts to keep any provided personal information confidential. Your information will be housed in a password protected drive and laptop that only I, Tristen Johnson, will have access. Information that may identify you will not be released to individuals outside of my dissertation. However, when required by law or university policy, identifying information (including your signed consent form) may be seen or copied by authorized individuals only.

Could your responses be used for other research? I will not use any identifiable information from you in future research, but your de-identified information could be used for future research without additional consent from you. The findings of this research may be disseminated after this dissertation at conferences or in a book.

Will you receive anything for participating? You will receive no compensation for participating in this research, and you may discontinue participation at any time without penalty or loss of any benefits to which you may otherwise be entitled. By participating in this study, you will be able to have access to your interview transcripts as well as the final draft of the study. You will also have the option to stay in communication with me after the study.

Who will benefit from this study? As the participant, you will be contributing to the existing literature on how to better support Black women professionals in higher education and Black women working in diversity positions specifically. Whom do you contact if you have any questions? If you have any questions about this research or wish to withdraw from the study, contact Tristen Johnson at 309-839-7243 or tristenjohnson1 @ gmail.com and/or the principal investigator Dr. Venus Evans-Winters at 309-438-4025 or vevansw @ilstu.edu If you have any questions about your rights as a participant, or if you feel you have been placed at risk, contact the Illinois State University Research Ethics \& Compliance Office at (309) 438- 
5527 or IRB @ilstu.edu. After reading this form, please provide documentation of your consent to participate in the study by checking yes or no to the options below. Documentation of Consent Yes, I am willing to be a participant in this study, and I am 18 years or older. (check the box) No, I am not willing to participate in this study. (check the box) 


\section{APPENDIX D: BIOGRAPHICAL QUESTIONAIRE}

1.Do you consent to this study?

a. Yes

b. No

2.First and Last Name

3.Email Address

4.Phone number

5. Which Functional area do you/did you work in?
a. Housing
b. Residential Life
c. Multicultural Affairs/Centers
d. Other

6.If you selected "other" for question 4, please specify. If you selected housing/residential life or multicultural affairs/centers, please write N/A

7. Do you identify as a Black woman?

a. Yes

b. No

8. What are your pronouns?

9. What is/was your job title?

10. Have you been/were you working in this diversity role for one academic year or more?
a. Yes
b. No 


\section{APPENDIX E: INSTITUTIONAL REVIEW BOARD APPROVAL}

Jan 21, 2020 12:28 PM CST

Venus Evans-Winters

Ed. Admin. \& Foundations

Re: Exempt - Initial - IRB-2019-530 Experiences of Black Women in Diversity Roles at Predominantly White Institutions

Dear Dr. Venus Evans-Winters:

Illinois State University Institutional Review Board has rendered the decision that your study meets the criteria for an exempt determination and you can begin the study covered under this protocol.

Your study qualified for: Category 2.(iii). Research that only includes interactions involving educational tests (cognitive, diagnostic, aptitude, achievement), survey procedures, interview procedures, or observation of public behavior (including visual or auditory recording) if at least one of the following criteria is met:

The information obtained is recorded by the investigator in such a manner that the identity of the human subjects can readily be ascertained, directly or through identifiers linked to the subjects, and an IRB conducts a limited IRB review to make the determination required by $\$ 46.111(\mathrm{a})(7)$.

The Exempt Status does not relieve the investigator of any responsibilities relating to the research participants or university policy. Research should be conducted in accordance with the ethical principles, (1) Respect for Persons, (ii) Beneficence, and (iii) Justice, as outlined in the Belmont Report. Any change to the protocol or study materials that might affect the Exempt Status must be submitted in Cayuse IRB. Depending on the changes, you may be required to apply for either Expedited or Full Review.

Please contact the Human Subjects Research Specialist to determine if your modifications meet these criteria at 309-438-5527 or tjdeeri@ilstu.edu.

Sincerely,

Illinois State University Institutional Review Board 